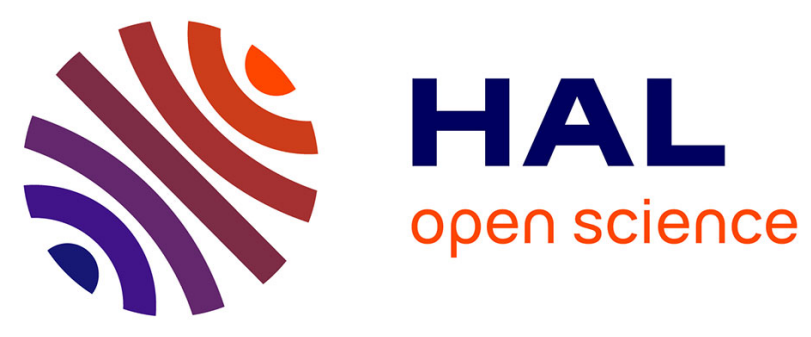

\title{
Natural Glasses
}

Maria Rita Cicconi, Daniel R. Neuville

\section{To cite this version:}

Maria Rita Cicconi, Daniel R. Neuville. Natural Glasses. J. David Musgraves; Juejun Hu; Laurent Calvez. Springer Handbook of Glass,, Springer, pp.771-812, 2019, Springer Handbooks, 978-3-31993726-7. 10.1007/978-3-319-93728-1_22 . hal-02989595

\section{HAL Id: hal-02989595 https://hal.science/hal-02989595}

Submitted on 26 Apr 2021

HAL is a multi-disciplinary open access archive for the deposit and dissemination of scientific research documents, whether they are published or not. The documents may come from teaching and research institutions in France or abroad, or from public or private research centers.
L'archive ouverte pluridisciplinaire HAL, est destinée au dépôt et à la diffusion de documents scientifiques de niveau recherche, publiés ou non, émanant des établissements d'enseignement et de recherche français ou étrangers, des laboratoires publics ou privés. 


\section{Natural glasses}

\section{Maria Rita Cicconi ${ }^{1}$ and Daniel R. Neuville ${ }^{2}$}

51 - Department Werkstoffwissenschaften, Lehrstuhl für Glas und Keramik, Universität

6 Erlangen-Nürnberg. Martensstrasse 5, D-91058 Erlangen

72 - Institut de Physique du Globe de Paris, CNRS, Géomatériaux, Sorbonne Paris Cité, 1, rue Jussieu, F- 75238 Paris

\section{Abstract}

On Earth, natural glasses are typically produced by rapid cooling of melts, and as in the case of minerals and rocks, natural glasses can provide key information on the evolution of the Earth. However, we are aware that natural glasses are products not solely terrestrial and that the formation mechanisms give rise to a variety of natural amorphous materials. On the Earth's surface, glasses are scarce compared to other terrestrial bodies (i.e. Moon), since the conditions on the surface give rise to devitrification or weathering.

In order to provide an exhaustive overview, we are going to classify natural glasses based on the mechanisms by which they were formed. When talking about natural glasses, the first image is that of an obsidian, a volcanic glass that has been used since prehistoric times and has accompanied and influenced human evolution. Indeed, the largest volumes $\left(\mathrm{km}^{3}\right)$ of natural glasses (e.g. obsidian, perlite and pitchstone) are linked to volcanic activity and associated with cooling close to the surface. Tektites and impact glasses are formed in a completely different way since their formation is related to the impact of an extraterrestrial body on the surface of the Earth. Therefore, since glasses are formed by different processes, 
we will provide a subdivision based on the formation mechanisms: temperature related, temperature-pressure related, temperature-pressure-volatiles related, and others:

- Quenched glasses

- Impact glasses

- Obsidian

- Others.

At the end we will provide some insights into the structure and properties of natural glasses and melts.

are referred to these exhaustive papers: i.e. [1-7]. An interesting nomenclature for natural glasses was provided by Heide and Heide [6], which divided natural non-crystalline solids into four main groups, depending on their origin: magmatic, metamorphic, sedimentary and biogenetic.

The chemical composition of natural glasses varies from mafic to felsic. Figure 1 reports the Total Alkali vs. Silica (TAS) diagram, where the compositions of many natural glasses (Table 1) have been recalculated to $100 \%$ excluding water and carbon dioxide. The enormous variability of natural glasses composition can be appreciated in the TAS diagram, since they are differentiated as many common types of volcanic rocks ([8]). Indeed, the diagram shows how widely natural glasses can vary in their composition, with $\mathrm{SiO}_{2}$ contents ranging from 30 to $99 \mathrm{wt} \%$, and total alkali contents ranging from $0 \%$ up to $15 \mathrm{wt} \%$. The list presented is, of course, not exhaustive, but represents many different glasses and their average compositions. 
51 Table 1 - Average composition of the major oxides (wt\%) in several natural glasses.

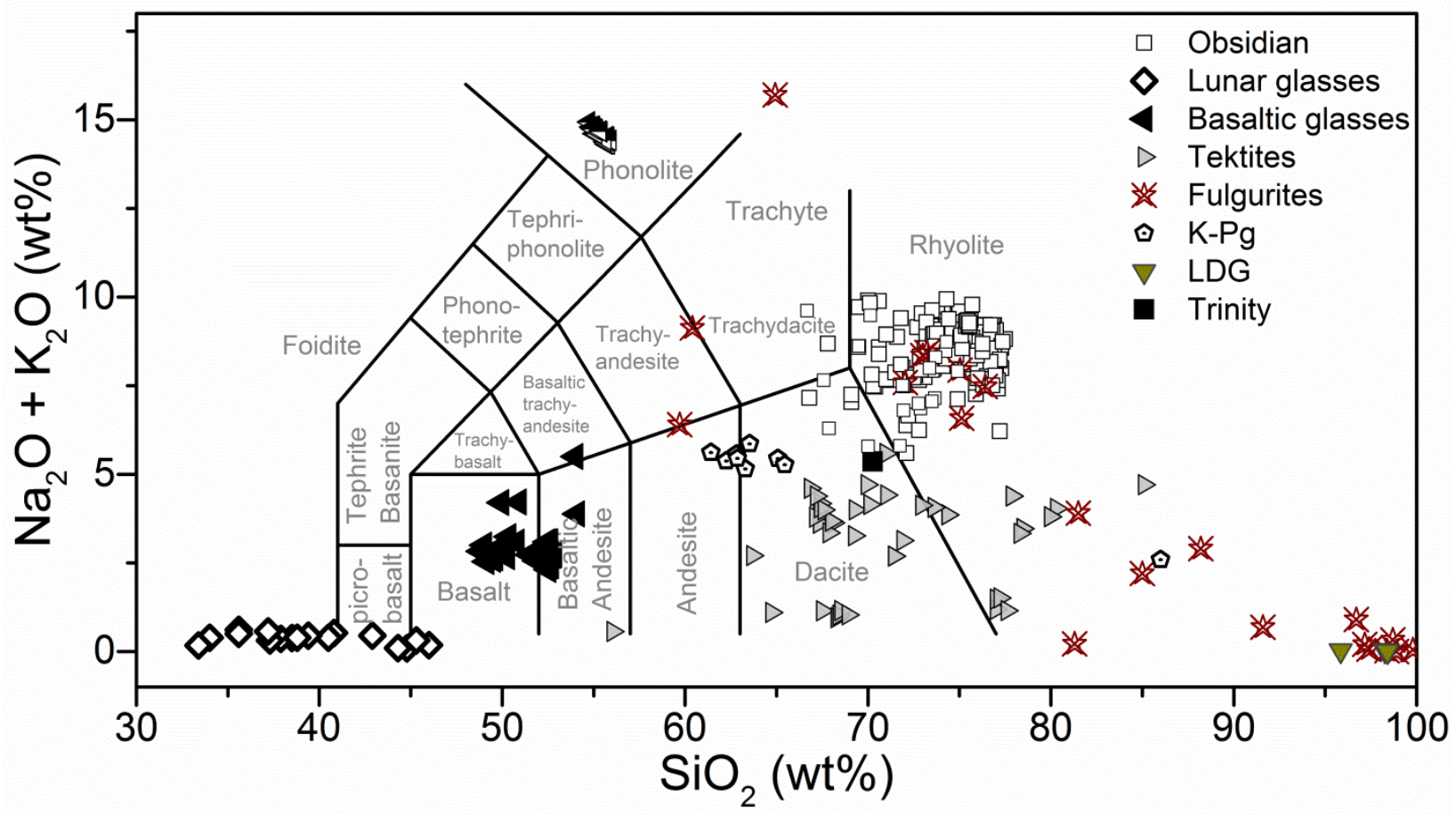

Fig. 1 - Total alkali vs. silica (TAS) diagram for several natural glasses (most of the data and references are reported in Table 1 ). 
CONTENTS

57

\section{1 - QUENCHED GLASSES}

1.1 - Volcanic glasses

Applications: alteration of natural glasses as analogue of nuclear waste glasses

1.2 - Lunar glasses

\section{2 - IMPACT GLASSES}

2.1 - Tektites and microtektites

2.2 - K-Pg (KT) spherules

2.3 - Younger Dryas (YD) event

2.4 - Enigmatic impact glasses

2.4.1 - LDG - Libyan Desert Glass

2.4.2 - Darwin glass

2.5 - Fulgurites

\section{3 - OBSIDIAN}

3.1 - Hydrated and altered obsidians

\section{4 - OTHERS}

4.1 - Glasses from nuclear explosion

4.2 - Friction melts

4.3 - Bioglasses

\section{5 - Insights into the structure and properties of glasses}

\section{6 - Conclusions}




\section{Important abbreviations}

$\mathrm{Ab}=$ albite $-\mathrm{NaAlSi}_{3} \mathrm{O}_{8}$

$\mathrm{An}=$ anorthite $-\mathrm{CaAl}_{2} \mathrm{Si}_{2} \mathrm{O}_{8}$

Basalt $=$ extrusive igneous rock (forms from lava that cools rapidly at Earth's surface)

Deep Sea Drilling Project (DSDP) = Multi-institution US programme operating a drilling ship for scientific sampling of the oceans from 1968 to 1985 [9]

Effusion rate $=$ the volume rate of lava production $\left(\mathrm{m}^{3} / \mathrm{s}\right)[8]$

FAMOUS $=$ French-American Mid-Ocean Undersea Study

Feldspar: group of silicate minerals (e.g. Anorthite, Albite, Orthoclase)

Felsic $=($ e.g. rhyolite $)$ term used for magmas/rocks enriched in lighter elements: $\mathrm{SiO}_{2}$, alkali elements and $\mathrm{Al}_{2} \mathrm{O}_{3}$.

Hypervelocity impacts = Impacts, involving impacting bodies that are traveling at speed (generally greater than a few $\mathrm{km} / \mathrm{s}$ ) higher enough to generate shock waves upon impact.

$\mathrm{K}-\mathrm{Pg}=$ Cretaceous$-\mathrm{Paleogene}(\mathrm{K}-\mathrm{Pg})$ boundary $(\sim 66$ million years ago $)$

$\mathrm{KT}=$ Cretaceous-Tertiary boundary (former name for K-Pg)

Lechatelierite $=$ shock-fused $\mathrm{SiO}_{2}$ glass

LDG $=$ Libyan Desert Glass

Mafic rocks $=($ e.g. basalt $)$ magmas/rocks with $\sim 50 \mathrm{wt} \% \mathrm{SiO}_{2}$, enriched in $\mathrm{Fe}, \mathrm{Mg}$ and $\mathrm{Ca}$, and usually dark in color.

$\mathrm{MN}=$ Muong Nong-Type tektites

MORB $=$ Mid-Ocean Ridge Basalt

Or $=$ orthoclase $-\mathrm{KAlSi}_{3} \mathrm{O}_{8}$

Planar deformation features $(\mathrm{PDFs})=$ microscopic parallel, isotropic features in minerals that originate from elevated shock metamorphism.

Pyroxenes $=$ group of silicate minerals (e.g. diopside $\left.\mathrm{CaMgSi}_{2} \mathrm{O}_{6}\right)$

$\mathrm{SF}=$ tektite/impact glass strewn fields

TAS $=$ Total-Alkalis versus Silica diagram

Tektites $=$ millimeter- to centimeter-scale, glassy particles of ballistically transported impact melt, formed by the impact of an extraterrestrial projectile. Microtektites are less than $1 \mathrm{~mm}$ in size. 
$113 \mathrm{Tg}=$ Glass Transition temperature

$114 \mathrm{YD}=$ Younger Dryas is a geological period from $\sim 12,900$ to $\sim 11,700 \mathrm{BP}$

$115 \quad \mathrm{YDB}=$ Younger Dryas boundary

116 Ultramafic rocks $=($ e.g. komatiite $)$ magmas/rocks with very low silica content $(<45 \mathrm{wt} \%$ $\left.117 \mathrm{SiO}_{2}\right)$.

$118 \quad \mathrm{Wo}=$ wollastonite $-\mathrm{CaSiO}_{3}$

$119 \quad \mathrm{XAS}=\mathrm{X}$-ray Absorption Spectroscopy

120 


\section{1 - QUENCHED GLASSES}

Basalt is a mafic igneous rock with a $\mathrm{SiO}_{2}$ content that lies between 45-52 wt\%.

Basaltic melts are produced in a wide variety of tectonic environments on Earth (and also occur on other terrestrial bodies including the Moon) [8], and can be classified depending on the geological setting in which they have formed.

Mid-ocean Ridges, where new oceanic lithosphere is continually built from mantle melting, has a total length of more than $60000 \mathrm{~km}$ and produce $\sim 21 \mathrm{~km}^{3}$ of lava per year. Mid - ocean ridge basalts (MORBs) are tholeiitic basalts (mafic magmas enriched in $\mathrm{Mg}$ and $\mathrm{Fe}$ ) that commonly contain phenocrysts of silicate minerals and oxides (e.g. olivine $(\mathrm{Mg}, \mathrm{Fe})_{2} \mathrm{SiO}_{4}$, chromite $(\mathrm{Mg}, \mathrm{Fe}) \mathrm{Cr}_{2} \mathrm{O}_{4}$, etc...) [8]. The most distinctive aspect of Mid - ocean ridge basalts is their chemical composition: i.e. most MORBs (normal MORB) have similar major element compositions, and are characterized by low contents of $\mathrm{K}_{2} \mathrm{O}$ and other incompatible elements. Another class of MORB, referred to as E-MORB (enriched MORB), has very different trace element compositions and is significantly enriched in the more incompatible elements [9]. The chemical variations observed between basalts from different terrestrial tectonic settings can provide key information about the processes by which basaltic melts are generated in the Earth's interior [8].

Basalt flows, erupted under water, differ in form from those erupted on land, and a variety of lava flow morphologies (typically classified as pillowed, lobate, or sheet flows on the basis of their morphology) is found at Mid-ocean Ridges. Pillow lavas (see Fig. 2) are approximately spherical or cylindrical bodies result from lower effusion rates, whereas sheet flows form from higher effusion rates [9]. The lobate morphologies is a type of bulbous lava flow wider and flatter than pillow lava, typical of intermediate effusion rates or flow on moderate sea floor slopes [9]. Indeed, Gregg and Fink [10] by carrying out 182 controlled laboratory simulations, in order to quantify the effects of effusion rate, cooling rate, and sea 
floor slope on lava morphologies, suggested that the variation from sheet flows to pillows

reflects a decreasing effusion rate for a given viscosity and sea floor slope [10].

Rapid quenching in cold seawater commonly results in a glassy matrix. Because of the

fast quench of basaltic melt causes fragmentation, submarine lava flows are often associated

with deposits of fine, glassy pieces called hyaloclastite (from the Greek: "glassy fragment").

The glassy fragments alter to a yellow or green-brown hydrated mass called palagonite (see

later).

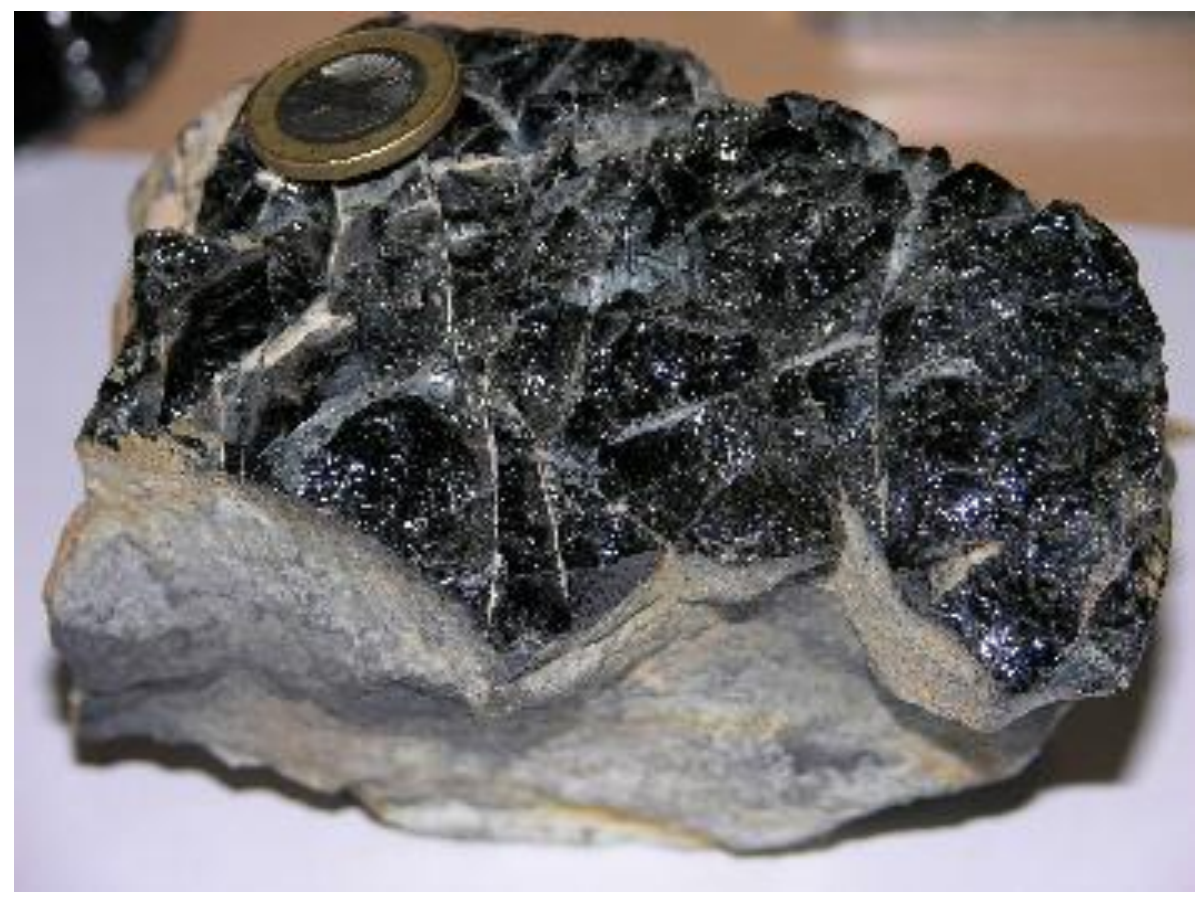

Figure 2 - Basaltic glass from French-American Mid-Ocean Undersea Study (FAMOUS) area on the Mid-Atlantic Ridge. Image copyright: D.R. Neuville.

Several studies have been devoted to understanding the oxidation state of Mid - ocean ridge basalt glasses since the redox state of the mantle is reflected in the oxidation state of MORBs (e.g. [11-14] and references therein). The understanding of the mantle redox equilibria is deeply linked to the magmatic differentiation, element partitioning, and speciation: e.g. C-O-H-S equilibria in magma and during degassing. 


\section{1 - Volcanic glasses}

Volcanism is not exclusively basaltic in all tectonic environments on Earth, even if basalts are found on the surface of the Earth in greater volume than any other volcanic type.

Basaltic glasses have an average composition of about (wt $\%$ ) $49-54 \% \mathrm{SiO}_{2}, 15-20 \%$

$\mathrm{Al}_{2} \mathrm{O}_{3}, 8-10 \% \mathrm{FeO}_{\text {tot }}, 2-5 \%$ alkali $\left(\mathrm{K}_{2} \mathrm{O}+\mathrm{Na}_{2} \mathrm{O}\right), 10-20 \%$ alkali-earth $(\mathrm{CaO}+\mathrm{MgO})[15]$ and

their low viscosity favors crystallization (devitrification). Volcanic glass commonly produced upon rapid cooling of melts of basaltic composition is called sideromelane. Basaltic glasses also occur as volcanic ash, fibers and teardrops (i.e. Pele's Hair and Pele's Tears) and more rarely form solidified foam - reticulite (Fig. 3) [16].

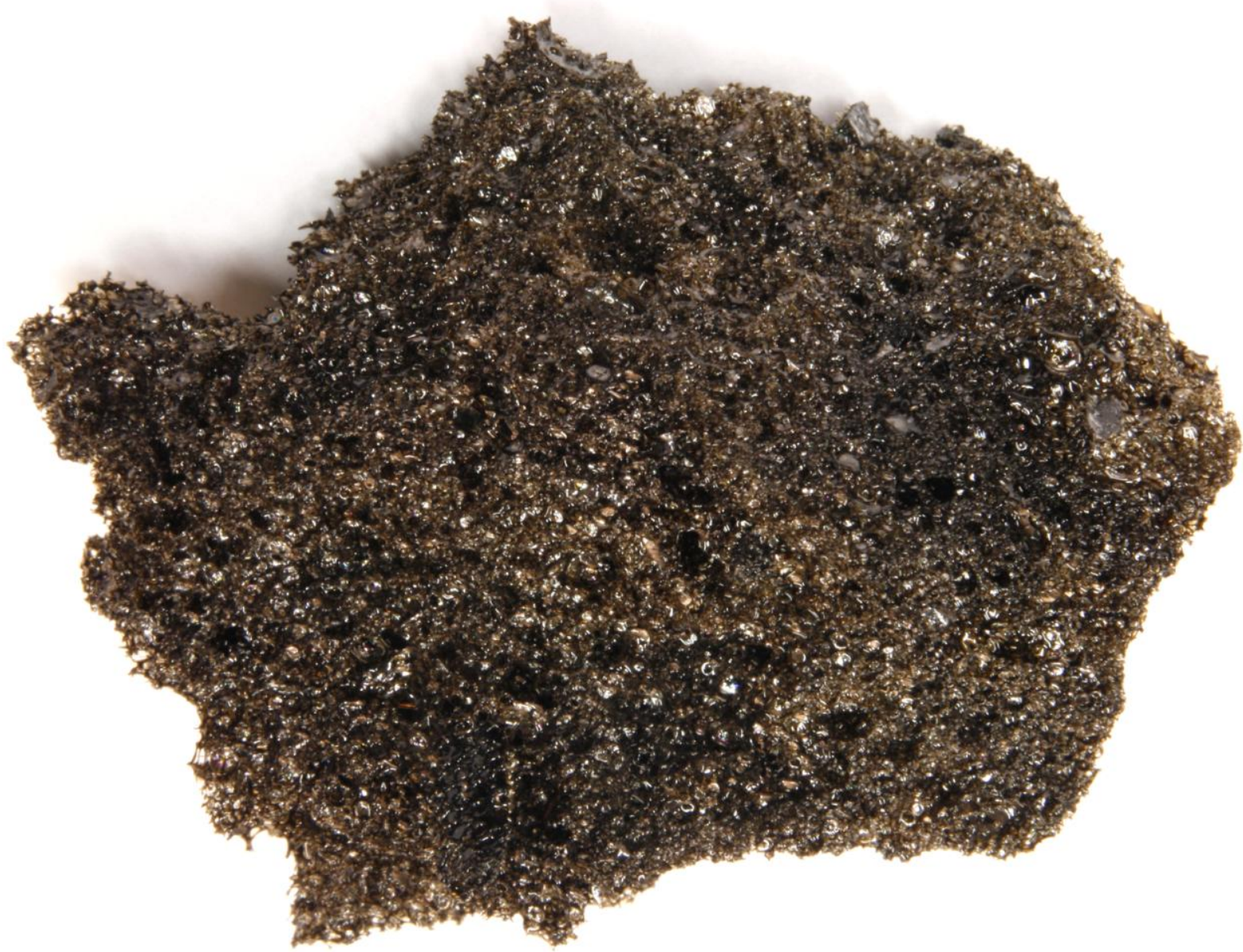

Figure 3 - Reticulite from Erebus volcano. This highly foamed sample is mainly composed of glass. Image copyright: D.R. Neuville (sample dimension 7x6x5cm). 

of diameter, and the droplet shape is mainly controlled by the surface tension, the acceleration of the droplet after eruption and air friction [17]. In contrast, Pele's hairs have cylindrical forms ( 1 to $500 \mu \mathrm{m}$ in diameter) and are extremely delicate (Fig. 4). Pele's hair and tears form during fountaining of the fluid lava (hawaiian-style eruptions) with an extremely high cooling rate. Hawaiian tholeiitic basalt magmas have temperatures of $1050^{\circ}-1200^{\circ} \mathrm{C}$, and gas contents ranging from 0.5 to $2 \mathrm{wt} \%$ [18] hence Hawaiian eruptions are characterized by the emission of very fluid lava. Shimozuru [19] suggested that Pele's hairs are produced when the velocity of erupting magmas is high and Pele's tears when it is "relatively" lower. Moune et al. [20] observed that Pele's tears can be associated with Pele's hairs after their formation. Pele's hairs have vesicles, typically parallel to the axis of elongation that break and often form long open cavities. Pele's tears can be also trapped on the walls and/or in these cavities [20]. These pyroclastic products are not solely associated to Hawaii volcanisms, since many other volcanoes produce them (e.g. Etna, Réunion, Masaya volcano, etc... ).

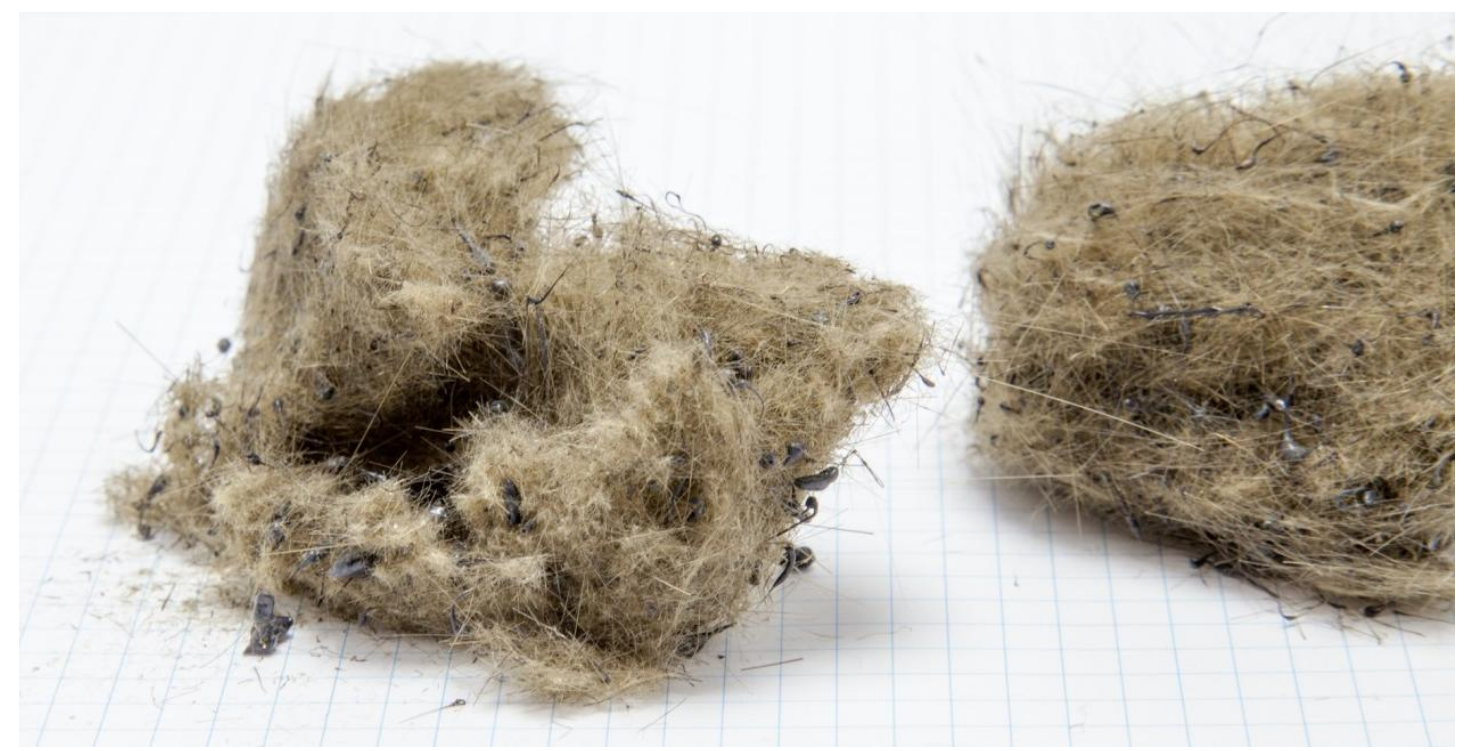

Figure 4 - Photograph of Pele's hairs along with few melt droplets (Pele's tears). Samples from Hawaiian Islands. Image copyright: D.R. Neuville (square dimension=5mm). 
Fiber is usually one of basic reinforcing elements of composite materials, and in the framework of developing environmentally sustainable composites, the use of natural fibers (e.g. basaltic fibers) has been an active field of study in the last decade [e.g. [21]]. Indeed, basalt fibers have properties, comparable to those of the synthetic ones, are cheaper of carbon fibers, and have even better mechanical properties than most types of E-Glass [22]. Fiore et al.[21] in their review report the main properties and several applications of basalt fibers.

Here we report a few of the advantages of the use of these fibers:

- use of natural basalt rocks as raw material, thus no additive needed;

- the manufacturing process of basalt fibers is similar to that of other glass fibers, but with less energy consumed (lower temperatures required), which makes it cheaper than glass or carbon fibers [21-23];

- mechanical properties similar to those of synthetic glasses (e.g. E-Glass) [21, 23]; - high thermal and chemical stability [21, 24];

one. There are few long-lived lava lakes, and among them the phonolitic lava lake of the Erebus volcano (Ross Island, Antarctic) has attracted many scientists. Both chemical and isotopic compositions of the magma in the Erebus lake have remained almost constant since the 1970s, when it was discovered [25, 26]. Erebus phonolitic magma/glass (Fig. 5) is Na enriched (average composition: $\mathrm{SiO}_{2} \sim 55 \mathrm{wt} \%, \mathrm{Al}_{2} \mathrm{O}_{3} \sim 20 \mathrm{wt} \%$, $\mathrm{FeO}_{\text {tot }}>5 \mathrm{wt} \%$ and alkali $\left(\mathrm{Na}_{2} \mathrm{O}+\mathrm{K}_{2} \mathrm{O}\right)>14 \mathrm{wt} \%$; see Table 1) and has low viscosities (for an anhydrous and crystalfree melt, in the temperature range $\sim 670-770^{\circ} \mathrm{C}$, viscosity ranges between $10^{10}$ and $10^{12} \mathrm{~Pa}^{*} \mathrm{~s}$ [27]).

Interestingly, foamed phonolite has been observed in some lava bombs from the Erebus. Kyle [28] describes some phonolitic bombs as extremely breakable samples, since they consist of highly pumiceous - dark green to black - glass with anorthoclase phenocrysts. 
The bombs are "fusiform" and highly vesiculated with the size of vesicles from 1-2 mm up to $40 \mathrm{~mm}$ on the surface and with some of the holes crossed by fine glassy hairs.

The small thickness of basaltic glasses that are formed by natural processes, along with a strong tendency to devitrify, result in the alteration of basaltic glass in relatively short time (a few thousand to tens of thousands of years) [29]. The alteration processes of volcanic glasses, and in particular the formation of secondary minerals, is an extremely important topic of study, and in a review paper, Stroncik and Schmincke [30] listed three main reasons: i) the alteration of volcanic glass influences the chemistry of natural waters; ii) the economic relevance of bentonite deposits (clay mineral) formed by the alteration of pyroclastic materials; iii) the alteration processes of natural glasses can be used as analog for modeling

241 the long-term stability of glasses used for nuclear waste immobilization (see below). 
244 [30]. Palagonite is considered the first stable product of the alteration caused by the

245 interaction of glass and aqueous solutions (Fig. 6). Indeed, basaltic glass in contact with water

246 forms this alteration zone whose thickness increases linearly with time [29]. The occurrence

247 of this layer has been confirmed under various alteration conditions, and it can be more or less crystalline and commonly associated with the presence of clays (e.g. [30, 31]).

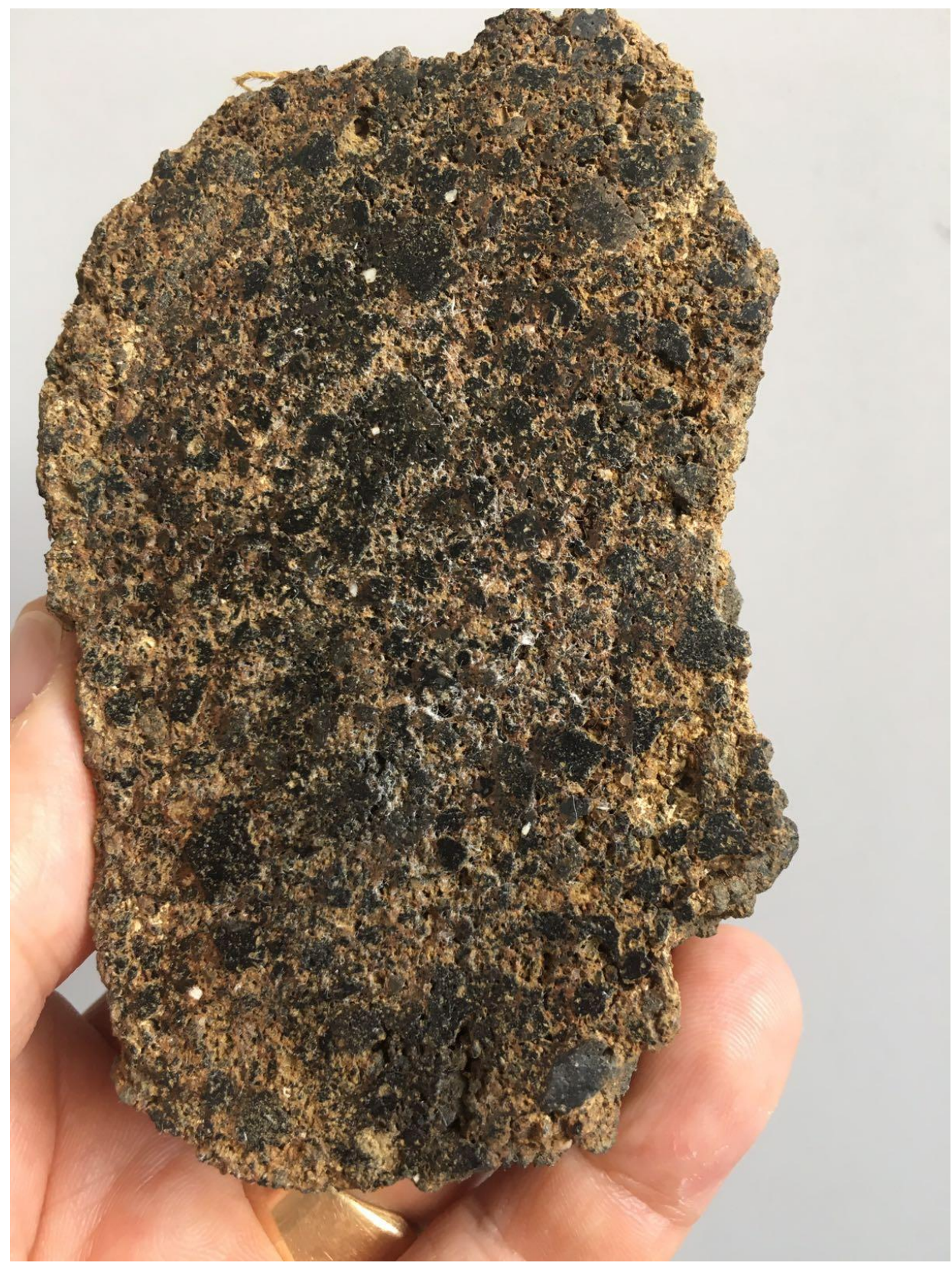

Figure 6 - Palagonite specimen. Image copyright: D.R. Neuville. 
253

254

255

256

257

258

259

260

261

262

263

264

265

266

267

268

269

270

2711 - Breakdown of glass in a water-free environment is too slow to be of concern for the

272 periods of time required for safe waste disposal;

273

2- Contact between glass and a hot aqueous phase accelerates all processes of glass alteration.

274 Glass hydration and dissolution rates become fast enough that significant alteration of glass 275 can occur in the period required for hazardous radionuclides to decay;

\section{Applications: alteration of natural glasses as analogue of nuclear waste glasses}

The study of basaltic glasses is not only related to Geoscience (s.l.) for understanding the eruptive processes, or for understanding the formation of economic mineral deposits.

Natural basaltic glasses have been widely used as analogues in studies for evaluation of the long-term stability of nuclear waste form glasses [32, 33] because a challenging aspect of nuclear waste repositories is the extrapolation of short-term laboratory data (hours to years) to the long time periods (hundred to thousand years) [34]. Therefore, in the last decades many studies have been devoted to get information from natural analogues, in order to corroborate predictive models of the long-term processes which affect the stability of radioactive waste repositories, since they provide the opportunity to examine processes occurring over geological timescales (natural basalt provide data on the alteration behavior of amorphous materials over tens or hundreds of thousands years) (e.g. [35-38]).

From all the studies it has been highlighted that basaltic glasses and borosilicate nuclear waste form glasses appear to be similar in their corrosion rates and mechanisms despite the significant compositional differences. Thus, the alteration processes observed for natural basalt glasses are relevant to understanding the alteration of nuclear waste glass, as both appear to react via similar processes. An early study from Zielinski [35] on the stability of glass in geological environments report three main observations for natural silicate glasses: 
276 3- Other parameters that can influence hydration/dissolution rates of glass/water interaction,

277 include $\mathrm{pH}$, composition, salinity, etc... [35].

Byers et al. [37] reported that the alteration of basalt glasses in nature is driven by a

279 hydrolytic dissolution/re-precipitation mechanism which results in the formation of well-

280 defined iron-rich aluminosilicate surface layers (palagonite). Natural glass alteration is also

281 accompanied by the precipitation of authigenic cements (e.g., zeolites, clay minerals), and the

282 clay mineralization observed on natural glasses is very similar to that produced on laboratory

283 altered glasses [39, 40]. More recently, Techer and coauthors [38], Poinssot and Gin [41] and

284 Parruzot et al. [31] corroborate the analogy of alteration kinetics/mechanisms for natural and

285 synthetic basaltic glasses, archaeological glasses, and the SON68 (or R7T7) nuclear waste

286 glass (a simulated French inactive nuclear reference glass). 


\subsection{Lunar Glasses}

Lunar glasses with colours from red through green are widely distributed in lunar soil. Lunar glasses differ completely from terrestrial ones by the very low content of water or other volatiles, and really high contents of $\mathrm{MgO}$ and $\mathrm{FeO}$. The volcanic lunar glasses are mainly homogeneous spherules (50 $\mu \mathrm{m}$ to $1 \mathrm{~mm}$ in diameter) with compositions from basic to ultrabasic $\left(\mathrm{SiO}_{2} \sim 33-48 \mathrm{wt} \%, \mathrm{Al}_{2} \mathrm{O}_{3} \sim 4.6-9 \mathrm{wt} \%, \mathrm{TiO}_{2} \sim 0.26-16 \mathrm{wt} \%, \mathrm{MgO} \sim 11-20 \mathrm{wt} \%\right.$, and $\mathrm{FeO} \sim 16-24$ wt\%; see Fig. 1 and Table 1).

Since the Apollo missions, several homogeneous glass samples have been returned from six different lunar locations. Delano [2] distinguished 25 different types of lunar volcanic ejecta, which differ conspicuously from terrestrial volcanic ones both in composition and in shape, with the lunar ones, typically having extremely low silica content (see Table 1) and spherical shape [16]. The high variability of $\mathrm{TiO}_{2}$ contents led to several studies to understand the origin and differences of these glasses. Indeed, as pointed out by Delano [2] the $\mathrm{TiO}_{2}$ abundance variability could reflect the complex processes associated with lunar magma petrogenesis. Figure 7 shows the variation of $\mathrm{SiO}_{2}$ and $\mathrm{FeO}$ against $\mathrm{TiO}_{2}$ content in lunar glasses (data and references in Table 1). It is possible to distinguish several areas, depending on Ti content: the green glasses from Apollo 15 landing site have the lowest $\mathrm{Ti}$ content (low- $\mathrm{Ti}$ ) and are enriched in $\mathrm{SiO}_{2}$. On the contrary, orange/red/black glasses have high-Ti and lower $\mathrm{SiO}_{2}$ contents. The intermediate yellow glasses were found in samples from Apollo 14, 15 and 17 landing sites. Apollo 14 suite contains the highest iron content of all the known glasses [42] and some black glasses. 


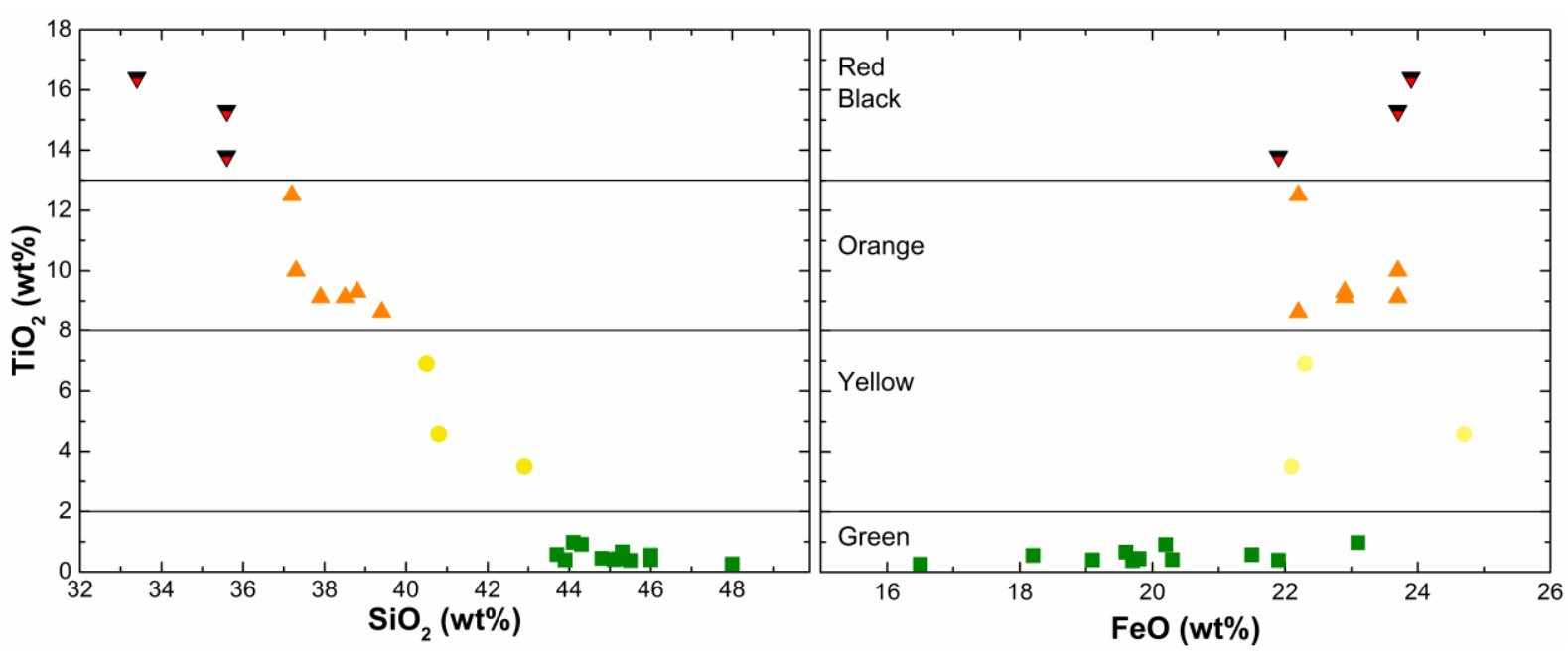

Figure 7 - Variation of $\mathrm{SiO}_{2}$ and $\mathrm{FeO}$ contents vs. $\mathrm{TiO}_{2}$ content in lunar glasses (data in Table 1). Modified after Delano [2] and Brown and Grove [42] and references therein).

Lunar glasses were at first believed to be of impact origin, but later studies pointed to volcanism. The Lunar Magmatism (so called Mare basalts) is represented by the dark smooth areas on the Moon. In addition to the eruption of large volumes of lava, the colored volcanic glass beads were produced by lava fountaining. These glass beads, as homogeneous quenched materials, provide some of the most important constraints to models of mare-basalt petrogenesis and for studying the characteristics of lunar interiors (composition, phase stability, thermodynamic parameters) [43]. Indeed, several studies on lunar glasses have been performed in order to provide constrains on models used to represent the lunar interior and insights into the thermal histories of lunar regions (experimental constraints on the origin of lunar ultramafic glasses e.g. [2, 44-51].

An examination of experimental data and thermal models is reported in a review by Shearer et al. [52]. From low-pressure phase equilibria experiments it was highlighted that glasses are characterized by (1) high liquidus temperatures, (2) olivine $\left((\mathrm{Mg}, \mathrm{Fe})_{2} \mathrm{SiO}_{4}\right)( \pm$ Chrome spinel, $\left.(\mathrm{Mg}, \mathrm{Fe})(\mathrm{Al}, \mathrm{Cr})_{2} \mathrm{O}_{4}\right)$ as the only liquidus phase, and (3) the remaining silicate and oxide phases are relegated to much lower temperatures [52]. These features suggest that the glass beads are primitive (least fractionated) magmas generated at considerable depths in 
the lunar mantle. The phase equilibria experiments on glasses provided range of pressure from 1.5 to $2.4 \mathrm{GPa}$ and high temperatures $\left(1430-1560^{\circ} \mathrm{C}\right)[52]$.

Particular attention has been given to quantifying the redox conditions on the Moon (the readers are referred to the exhaustive review by Wadhwa [53]). First of all, it is important to point that in Geosciences, the oxidation-reduction conditions of a system usually are described by using "redox buffer", that is the fugacity-temperature stability field for minerals and oxides (the phases coexist only at the buffer line). Examples of such redox buffers are:

- magnetite-hematite (MH)

- nichel-nichel oxide (NNO)

- iron-wüstite (IW)

$$
\begin{aligned}
& 2 \mathrm{Fe}_{3} \mathrm{O}_{4}+1 / 2 \mathrm{O}_{2}=3 \mathrm{Fe}_{2} \mathrm{O}_{3} \\
& 2 \mathrm{Ni}+\mathrm{O}_{2}=2 \mathrm{NiO} \\
& 2 \mathrm{Fe}+\mathrm{O}_{2}=2 \mathrm{FeO}
\end{aligned}
$$

Iron is one of the most abundant elements that exists in more than one oxidation state $\left(\mathrm{Fe}^{0}, \mathrm{Fe}^{2+}\right.$ and $\left.\mathrm{Fe}^{3+}\right)$, thus, generally the redox is expressed in terms of iron oxidation state, i.e., the relative proportions of the different iron valences [54]. $\mathrm{Fe}^{2+}$ and $\mathrm{Fe}^{3+}$ are most applicable to the range of oxygen fugacity $\left(f \mathrm{O}_{2}\right)$ in terrestrial and martian basalts[55]. Lunar basalts formed under significantly more reducing conditions than terrestrial basalts and the estimations of the $\mathrm{fO}_{2}$ conditions for lunar basalts and lunar glasses have been made using a variety of methods (e.g. [56-59]). Based on the several experimental works done, Moon redox conditions are estimated to range from $\sim 2 \log$ units below the Iron- Wüstite buffer ( IW-2) to close to the IW buffer [53]. For comparison, the range of oxygen fugacity on Earth can be represented by oxygen fugacity in the range IW +2 to IW +6 . Papike et al. [55] provided a schematic representation of the range of valence states of several multivalent elements with the range of $f \mathrm{O}_{2}$ of planetary basalts (relative to the IW buffer) (Fig. 1 in [55]).

Few Si-enriched glasses (with $\mathrm{SiO}_{2}$ contents $>60 \mathrm{wt} \%$ ) have been found in soil (and breccia) samples from the Apollo 11, 12, 14, 15 and 17 landing sites and from the Luna 16 
355 and 20 sites [60]. Among them Glass [60] found only one colorless (without vesicles or

356 crystalline inclusions) high-silica spherule. The analysis of these glasses results in an average

357 composition of the major elements similar to that of terrestrial volcanic glasses, even if the

358 lunar glasses have higher $\mathrm{K}_{2} \mathrm{O}$ and lower $\mathrm{Na}_{2} \mathrm{O}$ contents than the terrestrial ones. The author

359 studied both petrology and chemistry of several Si-enriched glasses and described the

360 origin/source of these material not as residual glass or impact-produced glasses from a

361 granitic source, but as products of lunar acidic volcanism [60].

362 


\section{2 - Impact glasses}

The generic term impactite refers to a large variety of rocks formed by the melting of crustal rocks during the impact of a large extraterrestrial body. A series of distinct materials (impactites) is generated by the forces of a hypervelocity impact, starting with shock compression and followed by decompression from peak shock pressures, with associated heat generation [61]. Depending on the pressure generated, several distinct markers will be formed, and by increasing pressure there are: planar deformation features (PDFs), diaplectic mineral glasses (produced without fusion), fused mineral glasses (produced with fusion), and melts [61].

We will mainly discuss the most homogeneous glasses created by such events, i.e. tektites. To distinguish "impact glasses" and tektites, Koeberl [62] provides the following characteristics for tektites: i) are amorphous and fairly homogeneous, ii) contain lechatelierite (amorphous $\mathrm{SiO}_{2}$ ), iii) occur within definite areas, called strewn-fields (SF), iv) tektites do not occur directly in or around a source crater (distal ejecta), and have v) low water content ( $<0.02 \mathrm{wt} \%$, at least an order of magnitude lower than the $\mathrm{H}_{2} \mathrm{O}$ content of volcanic glasses). Moreover, studies on iron oxidation state show that Fe is generally highly reduced in tektites, with almost all occurring as $\mathrm{Fe}^{2+}[63-66]$.

\subsection{Tektites and microtektites}

Tektites are small, black, glassy objects that are found only in certain areas of the Earth's surface. Most of the tektites are Si-rich glasses of various sizes (usually $>1 \mathrm{~cm}$ ), with typical aerodynamic shapes and very characteristic surface features (Figs. 8-9). Microtektites are microscopic tektites $(<0.1 \mathrm{~mm})$ found in deep-sea sediments [4]. 


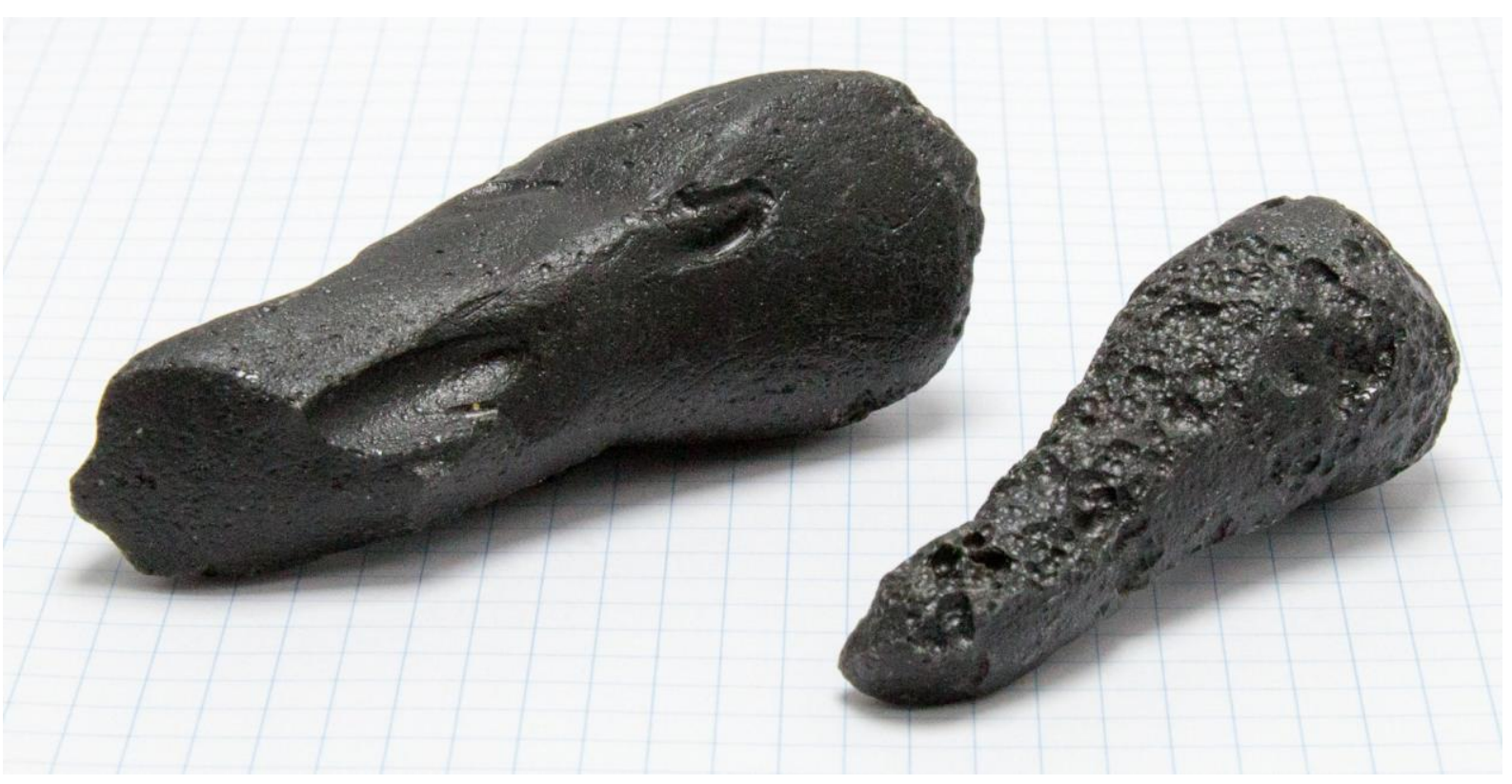

Figure 8 - Tektites specimens with the typical aerodynamic shapes and characteristic surface features. Image copyright: D.R. Neuville (square dimension $=5 \mathbf{m m}$ )

Based on their shapes it is possible to distinguish three types of tektites: Muong NongType (or layered), splash forms, and ablated/flanged tektites. Splash-form tektites (the most common form), include spheres, flattened ellipsoids, tear-shaped bodies (Fig. 8), rod-shaped bodies (generally thickened at both ends), canoes, and saucer-shaped objects [67].
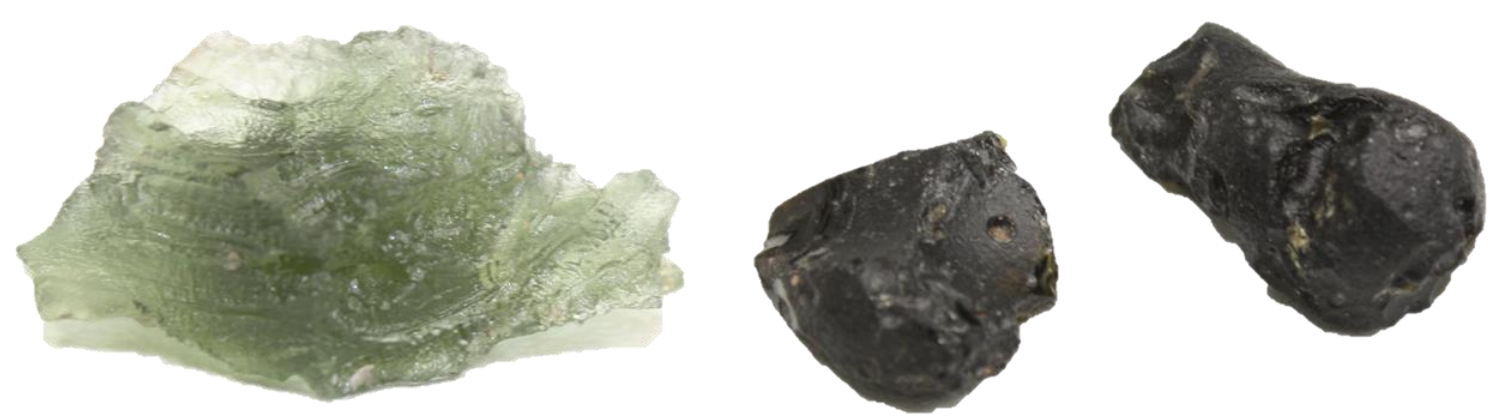

Figure 9 - Photos of some tektites, including a moldavite (length $\sim 18 \mathrm{~mm}$ ) and two indochinites (length $\sim 25 \mathrm{~mm}$ ). Image copyright: M.R. Cicconi

To date, four main groups of tektites, associated with separate impacts and strewn

fields (SF), are known (e.g., [68-71]): the North American, the Ivory Coast, the central European and the Australasian (Fig. 10). The source craters have been located for three of the 
four tektite strewn fields, based on geographic location, geochemical evidences, and composition [72-74].

The oldest strewn field is the North American (NA) field of $~ 35.5$ Ma age associated with the $\sim 40 \mathrm{~km}$ wide Chesapeake Bay impact structure [75] and includes Bediasites, Georgianites, Barbados and Cuba tektites, respectively found in Texas, Georgia, Barbados and Cuba (Fig. 10). The central European (CE) or moldavite strewn field of $14.4 \mathrm{Ma}$ age is associated with the Ries crater of about $24 \mathrm{~km}$ in diameter (Nördlinger Ries, Bavaria, D). There is another impact crater, the Steinheim crater, $~ 3.8 \mathrm{~km}$ in diameter, located about 42 kilometers west-southwest from the centre of Ries. These two craters are believed to have formed nearly simultaneously by the impact of a binary asteroid [76]. The Ivory Coast (IC) tektite strewn field is associated with the $1.07 \mathrm{Ma}$ old Bosumtwi crater (10.5 km diameter, Ghana, Africa). The youngest SF, of about $0.8 \mathrm{Ma}$, is the Australasian one, for which no source crater has been identified so far. Tektites of the Australasian strewn field (AA) include australites, thailandites, indochinites, philippinites and javanites and spread from the southeastern region of Asia down to Australia (Fig. 10). Recently, glass spherules (microtektites) were discovered on the Victoria Land Transantarctic Mountains (Antarctica) and there is clear evidence $[69,77,78]$ that these microtektites represent a major southeastward extension of the Australasian strewn field.

Even if no source crater has been discovered yet, several authors suggest a location for the AA crater in the Indochina region (see [79-82]). 


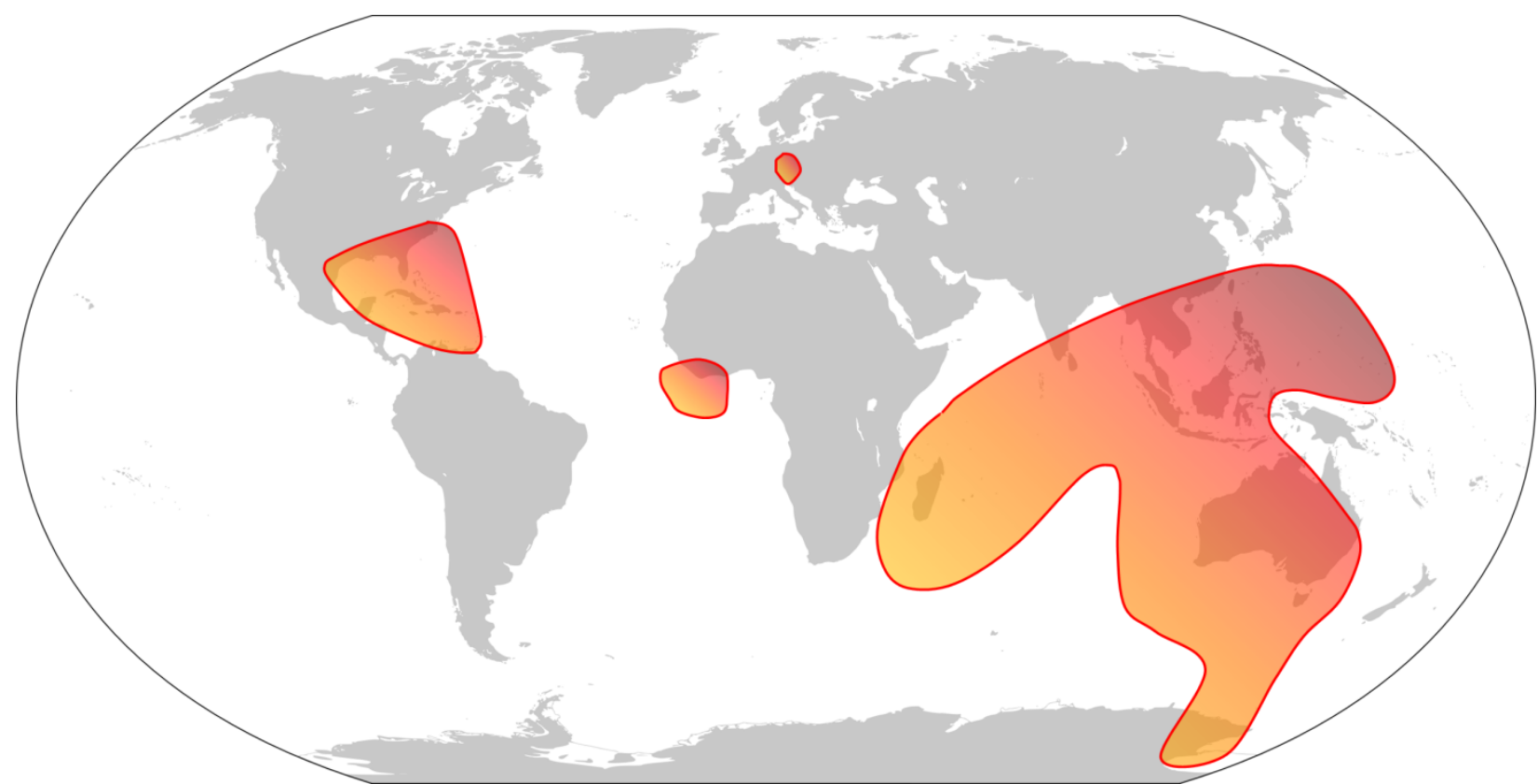

Figure 10 - Approximate location and extension of the four strewn fields: NA (North American), IC (Ivory Coast), CE (central Europe) and Australasian (AA). The location of the known source craters are Chesapeake Bay (NA), Ries (CE) and Bosumtwi crater (IC). Image copyright: M.R. Cicconi

Three of the four tektite strewn fields so far known also present microtektites

(diameter $<0.1 \mathrm{~mm}$ ): the North American, the Ivory Coast, and the Australasian SF. These spherules have been found in deep-sea deposits (see, e.g. [4, 83-85]) and are very important for defining the extension of the strewn fields (e.g., [86]), for constraining the stratigraphic age of tektites, and to provide an indication regarding the location of possible source craters (e.g., [79]). Trace element abundances confirm that microtektites are genetically related to tektites in the associated strewn field [87], but microtektites usually show a wider compositional range than tektites. Glass [4] assigns the different methods of analysis used, to explain the compositional differences between microtektites and tektites. A difference between microtektite and tektite samples was recently found by Giuli and coauthors [88]. The authors have shown that some North American microtektites present higher $\mathrm{Fe}^{3+} / \mathrm{Fe}^{2+}$ ratio (up to 0.61 ), compared to the respective tektites, implying that, probably, different formation mechanisms are involved for the formations of such small objects [88]. 
Muong Nong-Type tektites (MN - named after a region in Laos) are a subgroup of tektites that are unusually large (up to several tens of centimeters in size) and with layered structures. $\mathrm{MN}$ tektites are enriched in volatile trace elements (e.g., $\mathrm{Cl}, \mathrm{Br}, \mathrm{Zn}, \mathrm{Cu}, \mathrm{Pb}$ ), present chemical heterogeneity (darker and lighter layers), and may contain relict mineral grains (e.g. corundum, quartz, chromite and cristobalite) and bubbles [71]. Muong Nong-Type tektites strongly differ from volcanic glasses because of the presence of shocked mineral inclusions, for differences both in major and trace element contents (e.g. REE patterns), very low water content, highly reduced iron and the presence of ${ }^{10} \mathrm{Be}$ [89]. Koeberl [89]observed that Muong Nong-Type tektites contain higher abundances of the most volatile elements (the halogens, $\mathrm{Cu}, \mathrm{Zn}, \mathrm{Ga}, \mathrm{As}, \mathrm{Se}, \mathrm{Pb}$ ) compared to the splash-form tektites (the most common tektites). The presence of relict mineral grain, and the relatively higher water amount in Muong Nong-Type tektites suggest that MN have experienced the lowest temperatures of all tektites [89]. Is assumed that Muong Nong-type tektites have been deposited closer to the source crater and that they derive from a greater depth in the target deposits than were most of the other tektites [82].

The details of tektite and microtektite formation and on their distribution from the source crater are unknown and greatly debated. Numerical modeling indicates that highvelocity impacts $(35-40 \mathrm{~km} / \mathrm{s})$ into a dry target with impact angles of $30^{\circ}$ to $50^{\circ}$ may provide the best conditions for tektite production $[90,91]$. Indeed, the position of the strewn fields, with respect the inferred parent crater, indicates that tektites formed after oblique impacts. However, the tektite-producing impact processes still have several open questions [92] because physical and mathematical models are hampered by the limited information available (e.g. the importance of superheating), and because the impact process is a highly nonequilibrium and heterogeneous process. For instance, the exact target rocks from which 
tektites have been produced are not known yet, because it would require an accurate understanding of the physical-chemical processes, which may alter the chemical composition of the target rocks during impact. Moreover, the extent of volatilization, the state of tektite material after impact melting, or, what the size distribution of the melt droplets is [93], are still not understood. Engelhardt and coauthors [72] suggested that the tektite material is completely vaporized to a plasma state, and then the condensation from the plasma could form coalescing droplets. The hypothesis of tektite formation from a vapour plume might explain the ejecta homogeneity, and also the rapidity of homogenization of large volumes and the long distance transport. More recently, Johnson and Melosh [94] investigated droplets formation in impact produced vapor plumes and defined a linear correlation between the size of the ejected droplets and the size of the impacting object.

\section{2 - K-Pg (KT) spherules}

These small spherules $(100-500 \mu \mathrm{m})$, that resemble microtektites, were first detected in the Cretaceous-Paleogene K-Pg (formally known as KT- Cretaceous-Tertiary) layer in Gubbio (I) [95] and are associated with the most recent major impact event on Earth. Around 65-66 Ma ago there was the collision of an asteroid that caused a massive extinction with an impact crater of about $180 \mathrm{~km}$ identified on the Yucatan Peninsula and known as Chicxulub crater [96]. This large (cataclysmic) event is responsible for the formation of worldwide ejecta horizons, and caused the end-Cretaceous mass extinction, around $66 \mathrm{Ma}$ ago.

K-Pg distal impact ejecta layers are associated with Ir enrichments, siderophile element anomalies, shock metamorphosed mineral (quartz grains, coesite and stishovite) and rock debris. Because of the poor preservation of the claystone K-Pg boundary, there was an early discussion about the origin of these spherules. Some authors supported the impact hypothesis (e.g. [97]), whereas others attributed an authigenic origin for those microspherules (e.g. [98]). However, Sigurdsson et al. [99], by studying the glasses preserved at the K-Pg 
layer at Beloc in Haiti, provide clear evidences of an impact event. Moreover, Koeberl [100] and Koeberl and Sigurdsson [101] also provided exhaustive geochemical data for the impact origin of these Haitian Si-rich glasses and reported the occurrence of rare inhomogeneous glasses with lechatelierite and other mineral inclusions, which are typical for an origin by impact [100]. In particular, the identification of Planar deformation features (PDF) in quartz in the $\mathrm{K}-\mathrm{Pg}$ boundary-event bed was the key for the acceptance of this layer as an impact horizon [102]. Usually PDFs occur in silicate minerals, such as quartz and feldspars, which develop PDFs at pressures between 10-15 and 35 GPa. [71]

The study of the K-Pg boundary ejecta provided the most influence for the discussion about the importance of impact events with respect to the evolution of the planet and of life, and the detailed study of a K-Pg distal impact ejecta layers had led to the discovery of one of the largest impact structures on Earth - the $180 \mathrm{~km}$ Chicxulub crater [93].

\section{3 - Younger Dryas Spherules}

The Younger Dryas (YD) event is the name of a hypothesized impact event that may have occurred at the beginning of the Younger Dryas ( 12.8 ka), and as emphasized by Bunch et al. [103], "impact” denotes a collision by a cosmic object either with Earth's surface, producing a crater, or with its atmosphere, producing an airburst.

This hypothetical impact event seems to be supported by several markers, listed by Firestone and coauthors [104]. The authors describe the occurrence of a $<5$-cm-thick sediment layer dated ca. $12.9 \mathrm{ka}$ in several sites in North America ([105] expand the list and report also a few layers in Europe and in Syria). The markers include: magnetic microspherules, grains enriched in Ir, vesicular carbon spherules, glass-like carbon, nanodiamonds, fullerenes containing extraterrestrial concentrations of ${ }^{3} \mathrm{He}$, the presence of singular forms of soot, and charcoal. 
Younger Dryas boundary (YDB) spherules resemble the K-Pg spherules. Wittke et al.

$521[105]$ report detailed geochemical and morphological analyses of nearly 700 glass spherules

522 from quite a few sites. These samples are Fe-and/or Si-rich magnetic spherules with

523 dimensions ranging from $10 \mu \mathrm{m}$ to $5.5 \mathrm{~mm}$ in diameter, with shapes from simple spheroids, to

524 teardrops and dumbbells. The authors describe three groups of YDB objects based on

525 chemistry: i) an Al/Si group, ii) a Fe-rich group, and iii) a high-Si/low-Al group. Some scoria-

526 like objects and spherules are mainly composed of shock-fused vesicular lechatelierite,

527 whereas other present enrichment in Fe. Wittke et al. [105] conclude that these spherules are

528 geochemically and morphologically comparable to cosmic ejecta associated to other high-

529 energy events. Despite all this evidence, the hypothesis of the YD impact or airburst is still

530 largely debated, since most of the reported markers could not be confirmed in independent

531 studies. In the last few years several arguments for and against this hypothesis have been

532 published, and the readers are referred to: (e.g. Surovell et al. [106], Pinter et al. [107],

533 Boslough et al. [108], Van Hoesel et al. [109]).

The YD impact is not the only debated event, and recently, Reimold and coauthors

published a detailed paper on impact controversies [110]; e.g. the Maniitsoq structure

536 (Greenland), and the unconfirmed Khebira (Egypt), Arkenu (Libya), Bedout (Australia) craters $(c f .[110])$.

\section{4 - Enigmatic Impact glasses}

Glass and Simonson [71] in their review on distal impact ejecta describe the occurrence of glasses, believed (almost certainly) to be of impact origin, but not found in stratigraphic contexts. These natural glasses have been found in several locations on Earth, and we are going to describe two of the most famous: i) Libyan Desert Glass, and ii) Darwin glass. 


\subsection{1 - Libyan Desert Glass - LDG}

In an area of about $6500 \mathrm{~km}^{2}$ in southwest Egypt, close to the border with Libya, fragments of a natural silica-rich glass, known as Libyan Desert Glass (or LDG, Fig. 11), of age 28-29 million years, are found $[111,112]$. Since its discovery, early in the 20th century [113] the origin of the Libyan Desert Glass still represents an unanswered enigma to all scientists and researchers. However, an origin by impact seems the most plausible mechanism. In fact, LDG fragments are thought to be the remains of a glassy surface layer, resulting from high temperature melting of sandstones/desert sand, caused either by a meteorite impact, or - to explain the absence of an impact crater- by airburst (shock melting caused by a cosmic object exploding in the atmosphere) $[5,114]$.

LDG is very silica-rich (about $96.5-99 \mathrm{wt} \% \mathrm{SiO}_{2}$; see Table 1) and shows a limited variation in major and trace element abundances. The remaining few wt $\%$ are oxides of iron, titanium, calcium, and magnesium plus a few other oxides. LDG occurs as centimetre- to decimeter-sized, irregularly shaped, and strongly wind-eroded glass pieces (Fig. 11). The age of the LDG was mainly made by fission-track methods. Indeed, due to the low $\mathrm{K}$ content of the glass, the age errors from the K-Ar determinations are too high to be meaningful ([115] and references therein). The fission track dating from different investigation provides similar ages: $28.5 \pm 2.3 \mathrm{Ma}$ to $29.4 \pm 0.5 \mathrm{Ma}[116]$, and $28.5 \pm 0.8 \mathrm{Ma}$ [111]

Evidences for an impact origin include the presence of detectable amount of Ir [117] lechatelierite and baddeleyite [118] and, more in general, high pressure-temperature phases [119]. Moreover, the high concentration of Platinum-group elements [117], osmium isotope data of included dust, the presence of graphite-rich bands [120], and reduced Fe [121], are additional evidence for the impact origin.

Recently, Gomez-Nubla and coauthors [115] performed several spectroscopy measurements on LDG specimens (SEM-EDS, energy-dispersive micro X-ray fluorescence, electron microprobe, and optical cathodoluminescence) in order to identify and characterize 
the different phases. The authors identified several mineral phases, such as coesite, $\alpha-$ cristobalite, corundum, rutile $\left(\mathrm{TiO}_{2}\right.$ polymorph), and also not-high temperature phases, such as anhydrite $\left(\mathrm{CaSO}_{4}\right)$, gypsum $\left(\mathrm{CaSO}_{4} \cdot 2 \mathrm{H}_{2} \mathrm{O}\right)$, calcite, and aragonite (calcite polymorph).

Based on the presence of phases, stable both at high and at low temperatures and pressures, the authors delimited a range of $\mathrm{T}$ and $\mathrm{P}$ conditions during the impact event: from 300 to $>1470{ }^{\circ} \mathrm{C}$, and from 10 to $>30 \mathrm{GPa}[115]$. In 2007 a crater-like feature (Kebira crater, Gilf Kebir region, Egypt) was discovered by using satellite images and initially it was inferred as the source of LDG, because of its size, geographic location and topography. However, almost immediately it was disregarded since it lacked the geologic features associated with impact craters, such as impactites, breccias, and shatter cones. typical wind erosion surface. Image copyright: D.R. Neuville (square dimension=5mm). 


\subsection{2 - Darwin glass}

The Darwin Glass is found in a strewn-field of about $400 \mathrm{Km}^{2}$ in western Tasmania (Australia). The age of this glass, estimated by Ar-Ar methods, is around $800 \mathrm{ka}$ [122]. The glass generally occurs as irregular fragments, or masses, but small glasses (spheres and teardrops $<5 \mathrm{~mm}$ ) can be found across the Darwin SF. The color ranges from white, gray, light or dark green, dark brown, to black, and the glasses are generally vesicular and often exhibit flow structure marked by bands of elliptical vesicles [71]. Interesting, the proportion of white glasses is greatest in the proximity of the crater, and the proportion of darker glasses increase with distance from the crater $[123,124]$.

The Darwin crater, a small $(\sim 1.2 \mathrm{~km})$ simple impact crater formed in sedimentary target rocks, has been proposed as the source of Darwin glasses [125]. Howard and Haines [126] carried out a detailed petrographic study of the crater-filling samples, but no conclusive evidence of shock metamorphism has been found (e.g., shocked quartz grains, PDFs).

The chemistry suggests the presence of two main glass groups: the first one richer in $\mathrm{SiO}_{2}$ (average $\sim 85 \mathrm{wt} . \%$ ), and depleted in $\mathrm{CaO}$ and $\mathrm{Na}_{2} \mathrm{O}$, and a second one with a lower average abundance of $\mathrm{SiO}_{2}$ and a significant higher content of $\mathrm{MgO}$ and $\mathrm{FeO}$ [127].

Moreover, the second group is enriched in $\mathrm{Ni}, \mathrm{Co}$ and $\mathrm{Cr}$, with contents higher than in the surrounding sedimentary rocks. The enrichment in these elements (likely a meteoritic contamination), and the presence of coesite (high-pressure quartz polymorph) and lechatelierite seem to confirm the impact origin of these glasses [71].

Recently, Gomez-Nubla et al. [124] did a detailed investigation of Darwin glasses by using Raman spectroscopy, Energy Dispersive X-Ray Fluorescence, SEM-EDS and Electron Probe Microanalysis. The authors report that the same major elements were found in all the samples they analysed, with compositions ranging from: $\mathrm{SiO}_{2}=80-90$ wt. $\%$ (excluding the $\mathrm{SiO}_{2}$ pure inclusions), $\mathrm{Al}_{2} \mathrm{O}_{3}=5-9$ wt. $\%, \mathrm{FeO}=2-4$ wt. $\%, \mathrm{MgO}=0.3-0.8$ wt. $\%, \mathrm{~K}_{2} \mathrm{O}=1.8-$ 2.3 wt. $\%, \mathrm{CaO}=0.01-0.03$ wt. $\%$ and $\mathrm{TiO}_{2}=0.35-0.6$ wt. $\%$ [124]. Data from Raman 
spectroscopy identified, beside the silica glassy matrix, small inclusions of $\alpha$-cristobalite, and iron or iron/nickel oxides. In one specimen the authors also report the presence of secondary phases (formed or incorporated to the glass matrix after the impact, most likely due to weathering) [124].

\section{5 - Fulgurites}

Fulgurite is a glass formed as a result of fusion of rock by lightning in desert sands and in many other soils. Usually fulgurites consist of irregularly shaped tubes (Fig. 12) ranging from approximately $1 \mathrm{~cm}$ in diameter to $1 \mathrm{~mm}$, but that may extend laterally or vertically for up to $10 \mathrm{~m}$ [128]. The chemical composition of fulgurites is determined by the extremely high melting temperatures (peak temperatures of lightning up to $39000 \mathrm{~K}$ in the air and to heat target materials to temperatures around $2500 \mathrm{~K}$ ) and very short heating times (heating rate of the order of 1000K/s) [129-132]. In Table 1 are reported some chemical compositions from the literature and these studies suggest that fulgurites are typically enriched in $\mathrm{SiO}_{2}$. During the lightning strike in a mafic or ultramafic rock, $\mathrm{SiO}_{2}$ and $\mathrm{TiO}_{2}$ contents increase noticeably, and fulgurites formed in the sand dunes of the Libyan Desert Glass region have compositions that are similar to LDG. 


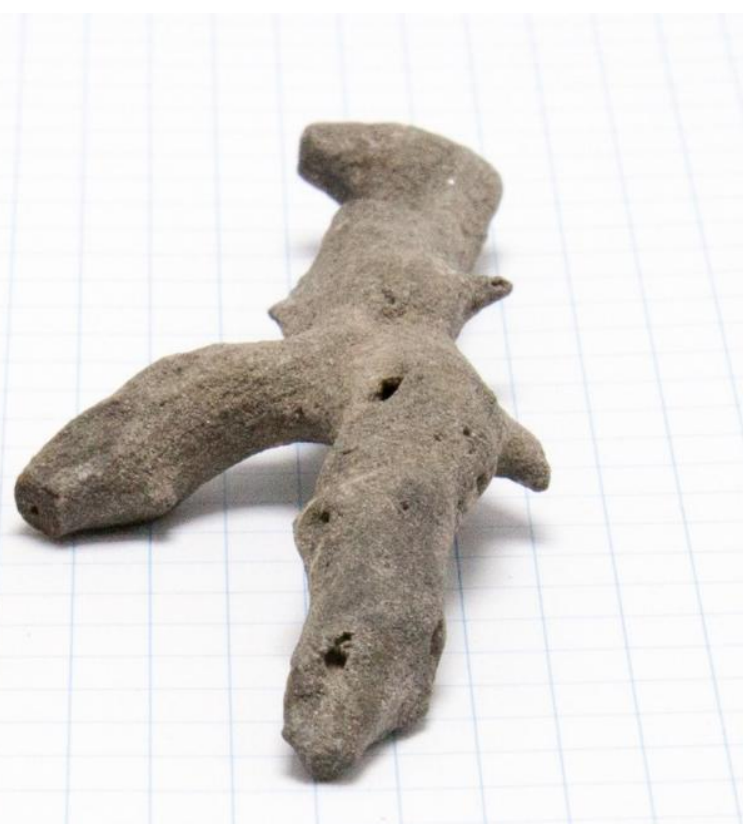

Figure 12 - Some fulgurite specimens with the characteristic irregular tube shapes. Image copyright: D.R. Neuville (square dimension=5mm).

A subdivision in five groups of fulgurites has been proposed by Pasek and coauthors [7] based on the different morphology and petrology occurring as a result of target material composition. According to Pasek and coauthors [7] it is possible to divide fulgurites in four main types of morphologies (plus a minor type):

- Type I fulgurites are formed in quartz sand and usually have thin glassy walls; Type I can contain one or two melts consisting prevalently of lechatelierite, and sometimes, also a $\mathrm{SiO}_{2}$-rich melt with higher concentrations of $\mathrm{Al}$ and/or $\mathrm{Fe}$. In the groundmass has been reported also enrichments in $\mathrm{Zr}$ oxide- and $\mathrm{Fe}-\mathrm{Ti}$ oxide- rich glass [7].

- Fulgurites type II has a lower amount of lechatelierite $(<50 \%)$, but higher glass thicknesses compared to fulgurites type I. The melt is more compositionally varied, because formed in different environments than quartz sand soils (e.g. soils composed also of clays minerals, quartz, and/or small rocks) [7]. 
- Type III consists of lechatelierite and feldspar glasses, and a calcite-rich matrix. Fulgurite type III, are mostly found in calcite-rich soils and are the densest (average density $^{1} 2.1 \pm 0.5 \mathrm{~g} / \mathrm{cm}^{3}$ ) [7]. No zircons were observed in the type III fulgurites.

- Type IV fulgurites are heterogeneous melts: with the outer portion consisting of unmelted (or partially melted) rocks and minerals. Type IV fulgurites form usually in bulk rocks and have densities similar to those of the target rocks.

- Type V droplet fulgurites are thoroughly mixed and have a homogeneous melt. The two main oxides contained in type $\mathrm{V}$ droplets are enriched in $\mathrm{SiO}_{2}$ and $\mathrm{K}_{2} \mathrm{O}$ relative to the originating fulgurite, whereas other oxides are depleted [7].

Usually the outer portion of a fulgurite tube is very rough and this is attributed to fragments of unaltered, or partially melted, minerals and rocks (Fig. 13). On the other hand the inner portion is mainly smooth and glassy (typically lechatelierite) and may also contain spherical inclusions: i.e. Pasek and Block [133] report iron phosphide spherules and Ca-P-Si oxide rich grains in type II fulgurites.
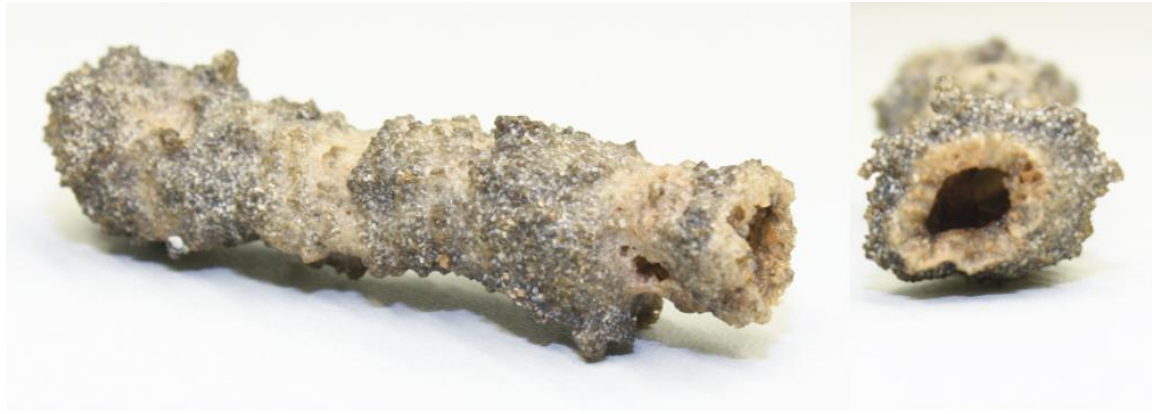

Figure 13 - Photographs of a fulgurite sample. The inner part is more smoothed and has a heterogeneous glassy material, whereas the outer portion is very irregular. Image copyright: M.R. Cicconi. Length of the specimen: $\sim 5.5 \mathrm{~cm}$.

\footnotetext{
${ }^{1}$ The density value reported is related to the density of the material as approximated by a whole fulgurite cylinder [7]..
} 

several explanations have been proposed to clarify the metallic oxide reduction occurring

674

675

676

677 during fulgurite formation. Essene and Fisher [128], explained the occurrence of metallic globules rich in silicon, or spheroids of silicon-bearing metals $(99.5$ at $\%$ of metallic silicon phase with minor amounts of titanium, iron, and phosphorus), via thermodynamic calculations that indicate that extremely high temperatures (> $2000 \mathrm{~K}$ ) and reducing conditions close to the $\mathrm{SiO}_{2}$-Si buffer were needed. Thus, the formation of coexisting metallic and silicate liquids was attributed to thermodynamic instability - at high temperature and strong reducing conditions - of the oxide species with respect to the metals. However the authors were not able to rule our other mechanisms, such as the presence of carbon, degassing of oxygen or formation of nitrogen oxide gases. Rowan and Ahrens [136] produced, by shock experiments, Fe-, Si- and Mo-rich metallic microspheres embedded in a shocked glass. Thus, there is the possibility that shockwaves induce reduction. Jones et al. [131], artificially (triggeredlightning) produced fulgurite specimens composed of $99.9 \%$ pure binary oxides of manganese and nickel in order to study the reduction mechanisms, and while they observed the formation of nickel oxide particles, the manganese oxide fulgurite showed no metallic phase formation. Hence, the mechanism proposed by Essene and Fisher [128] - the thermodynamic stability of an oxide - is the most likely. 
691

692

693

694

695

696

697

698

699

\section{3 - OBSIDIAN}

The most common natural glass deserves a special section. The Elder Pliny in his

famous 'Natural History', first described "obsiana", so named from its similarity to a stone

found in Ethiopia. The shape, the color and the properties of this volcanic glass (Fig. 14) have

been key factors for its use and contribution to Human history. Indeed, in prehistoric times it

was widely used for cutting tools or arrowheads (Fig. 15), but also for the production of

decoration and mirrors.

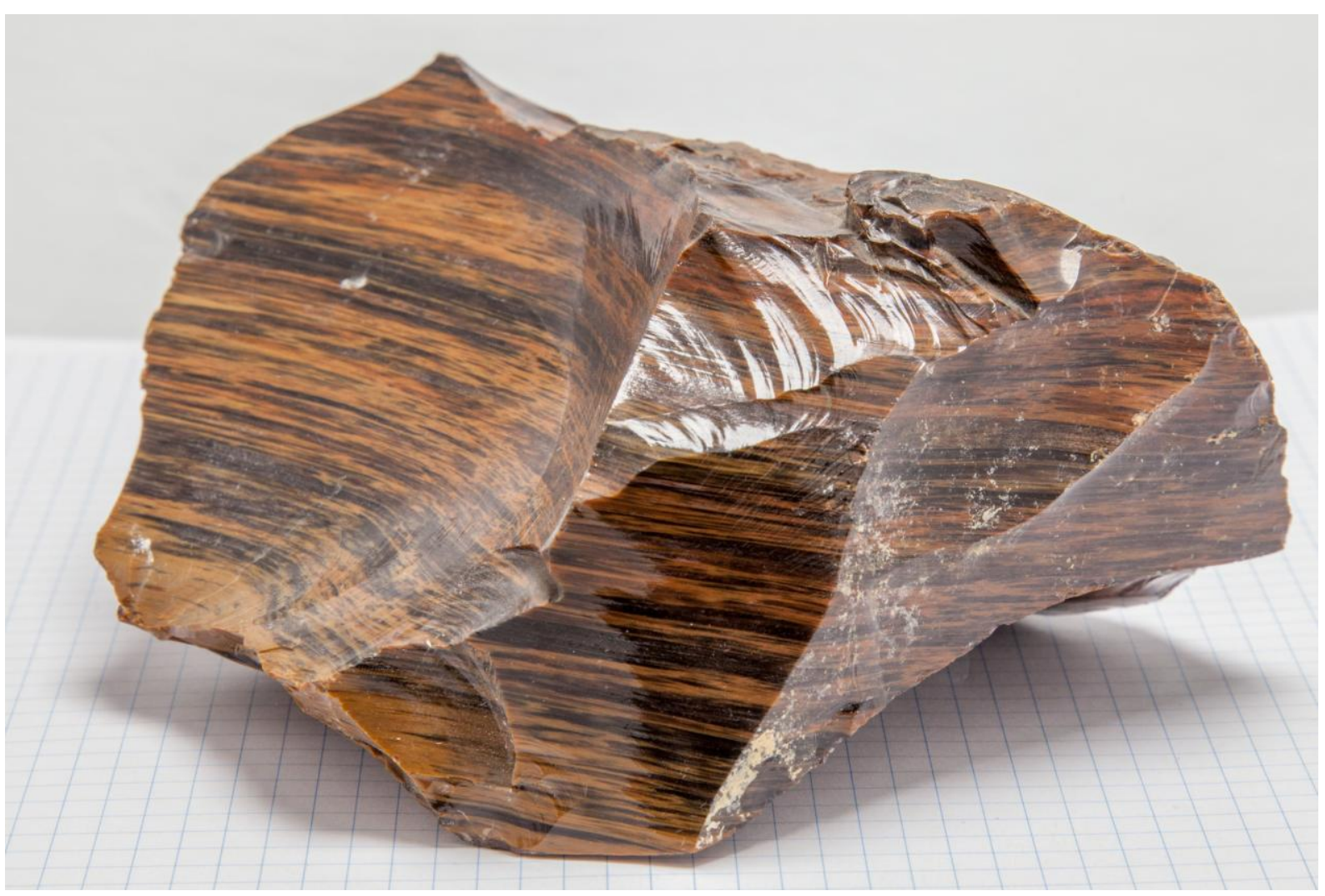

Figure 14 - Obsidian from Lipari (I). Image copyright: D.R. Neuville (square dimension=5mm).

Obsidian occurs in several geological settings [137], such as primitive and mature island arcs, active continental margins, continental interiors, and oceanic extensional zones and it occurs both as flows of several kilometers in length (e.g. exceptionally large obsidian flows in Oregon, USA) and as domes up to hundreds of meters high. There are a number of different types of obsidian occurring worldwide with different chemical compositions, and the 
average chemical compositions of some obsidians are reported in Table 1. Within each type,

there is a restricted range of major-element abundances; however the minor and trace elements can show order-of-magnitude variations [137]. Since the composition of this glass varies from place to place, the study of the minor (and trace) elements has been particularly useful for archeologists.

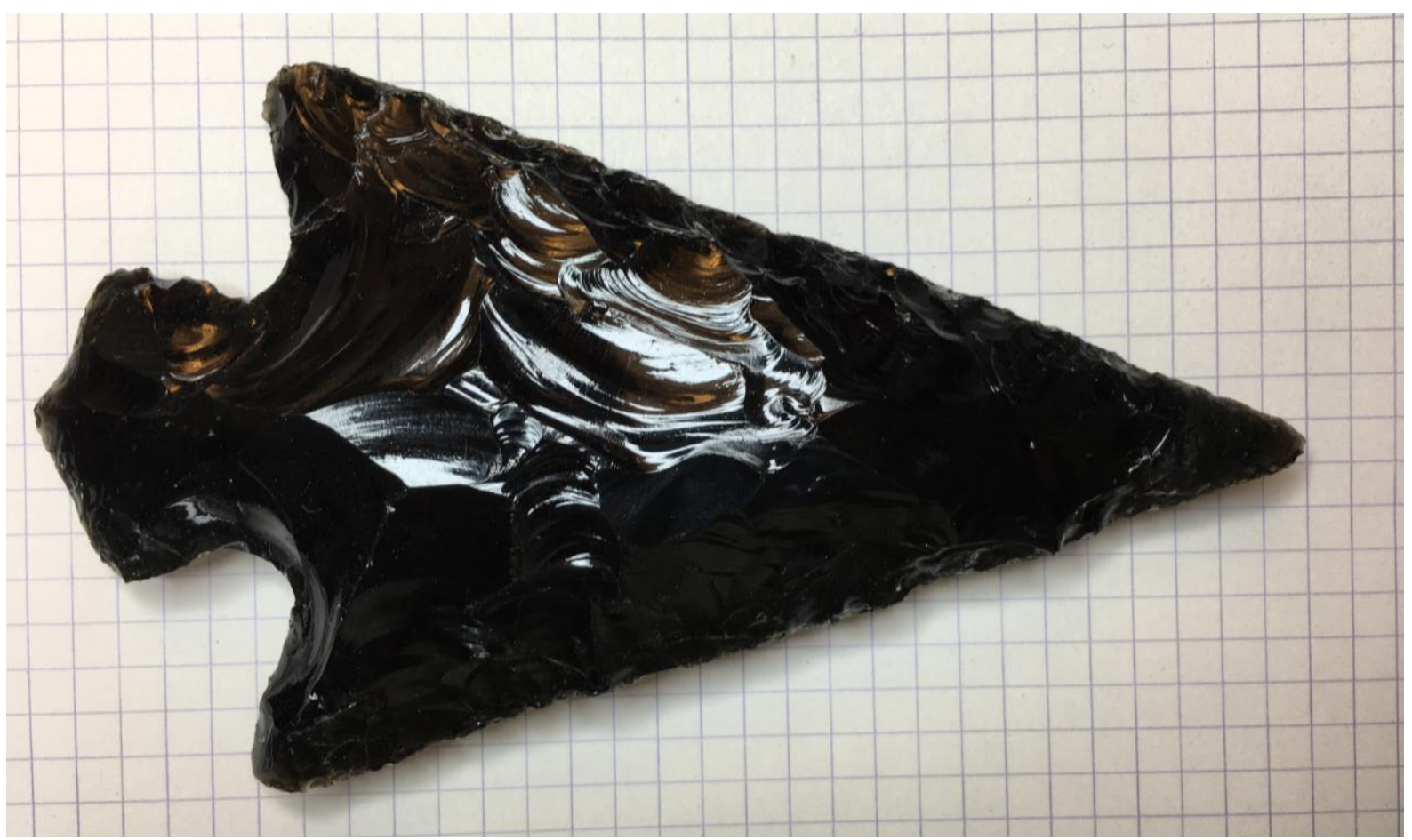

Figure 15 - Arrowhead made of obsidian. Image copyright: D.R. Neuville (square dimension=5mm).

The origin of the most common natural glass is not a simple matter of fast cooling.

The glass-forming processes of obsidian melt are strongly influenced by the contents of volatile components such as water, fluorine and chlorine, sulphur and carbon oxides [6, 138]. Indeed, small variations in volatile content can cause notable changes in the physical properties, such as rheology, which strongly influences flow dynamics of obsidian melts. Moreover, depending on various parameters such as temperature, pressure, chemical composition, water content, strain rate and also microlite (acicular crystals typically less than $10 \mu \mathrm{m}$ in length) preferred orientation [139], obsidian may exhibit elastic, viscous, or brittle behavior [140]. 
There are many studies focused on the chemistry and hydration of obsidians, but

curiously, there are not many studies on magnetical, mechanical and optical properties of these specimens that can provide strong insights on formation mechanisms and the nature of obsidians. An early study by Ericson et al. [141] provided an exhaustive study of 28 obsidian specimens and results from many techniques: thermal expansion, density measurements, Vicker's hardness, chemical durability, electrical properties, Mössbauer and infrared spectroscopy studies. The mechanical properties of obsidians are characteristic and differ from other glasses, such as windows glasses. However, the authors report also that obsidian is has high chemical durability, comparable to Pyrex, and high hardness, comparable with $\mathrm{SiO}_{2}$ glass [141].

Despite the dominant glassy matrix, obsidian specimens have several crystalline inclusions, such as Feldspars, pyroxenes, silica (and polymorphs), Fe a/o Ti, a/o Fe-Ti oxides (e.g. hematite $\mathrm{Fe}_{2} \mathrm{O}_{3}$, ilmenite $\mathrm{FeTiO}_{3} \ldots$ ), and in particular, obsidians have several coexisting paramagnetic, ferrimagnetic and/or superparamagnetic phases. To explain the complex magnetic behavior of obsidian, recently, Mameli et al [142] studied the magnetic and microstructural properties of 12 obsidian samples from Sardinia (I). By coupling several techniques the authors were able to discern that the presence of magnetite nanolites, dispersed into the obsidian glassy matrix, is responsible for the ferrimagnetism and superparamagnetism behaviours. Moreover, the coexistence of other two Fe-minerals could be responsible for the antiferromagnetic and paramagnetic behaviour [142]. location an "archaeological" obsidian came), and in particular, there are several studies on obsidians geochemical composition, fission-track dating, and chemical analyses [143]. Moreover, Mössbauer, Electron Spin Resonance, Raman spectroscopies, and magnetization have been largely used in provenance studies [144-147]. On the other hand, it is interesting to 
note that there are not many studies dedicated to the investigation of the redox state of obsidians. Indeed, as pointed out by Heide and Heide [6], many analyses have been concentrated only on the determination of the total Fe content. upon the presence of various transition elements along with the formation mechanisms, but obsidian is typically black or grey and sometimes occurs banded or streaky. However, it is possible to find several obsidian specimens with interesting optical properties, such as the socalled "rainbow", "sheen", or "fire" obsidian.

Rainbow obsidian shows iridescence bands of various colors, ranging from red through purple. Ma et al. [148] investigated the optical properties of rainbow obsidians with several techniques and they observed a correlation of the color bands both with the thickness and with the position of microcrystallites (pyroxenes or feldspars) within the samples.

Moreover, they identify as possible cause of the rainbow effect a thin-film interference. Arrays of crystallites produce interference effects, and the crystallites size and spacing control the rainbow effect.

Sheen obsidian usually is black to dark-brown and displays a single-color sheen, generally characterized by either a silvery or a golden hue. For a long time the sheen was assumed to be produced by reflections from oriented bubbles. However, Ma et al. [148] found that two kinds of vesicles coexist in these obsidians: vesicles filled with a slightly different glass or unfilled. In conclusion, Ma and coauthors [148] attribute the sheen to differences in indices of refraction between the glassy obsidian matrix and the lower indices of refraction of either gas-filled or glass-filled vesicles.

Fire obsidians have thin layers showing various colors. Indeed, under bright light, these glasses reflect colored bands resembling an iridescent oil slick. Ma et al. [149] reported that the iridescent layers were made of nano-particles of magnetite $\left(\mathrm{Fe}_{3} \mathrm{O}_{4}\right)$ that increased the 
777 refractive index, giving rise to thin-film interference and are the cause of the "fire" coloration 778 [149].

779

\section{1 - Hydrated and Altered obsidians}

Natural glasses are thermodynamically unstable at ambient temperatures and pressures and they slowly hydrate through the diffusion of water into the outer surface and along cracks. Natural rhyolitic glasses hydrated at temperatures below the glass transition $(\mathrm{Tg})$ are volcanic glasses that lately had a significant economic use in industry (e.g. supports of heterogeneous metal catalysts). The water-rich glasses are pumice, perlite and pitchstone. Pumices are microvesicular, volcanic "foam" materials formed by decompression of volatile -rich melts [8]. Thus, pumices have compositions close to that of obsidian, while after ejection they release the enclosed gas, forming a porous material. Perlite is a hydrated obsidian and the perlite deposits mostly occur as lava flows, dykes and domes. Perlitic glass which is relatively more altered, fractured and contains water $>4 \mathrm{wt} \%$ is often called pitchstone [150]. (Fig. 16), along with data for perlite and pitchstone, and it is possible to observe that the composition of the latters resembles that of obsidians (see Fig. 16). 


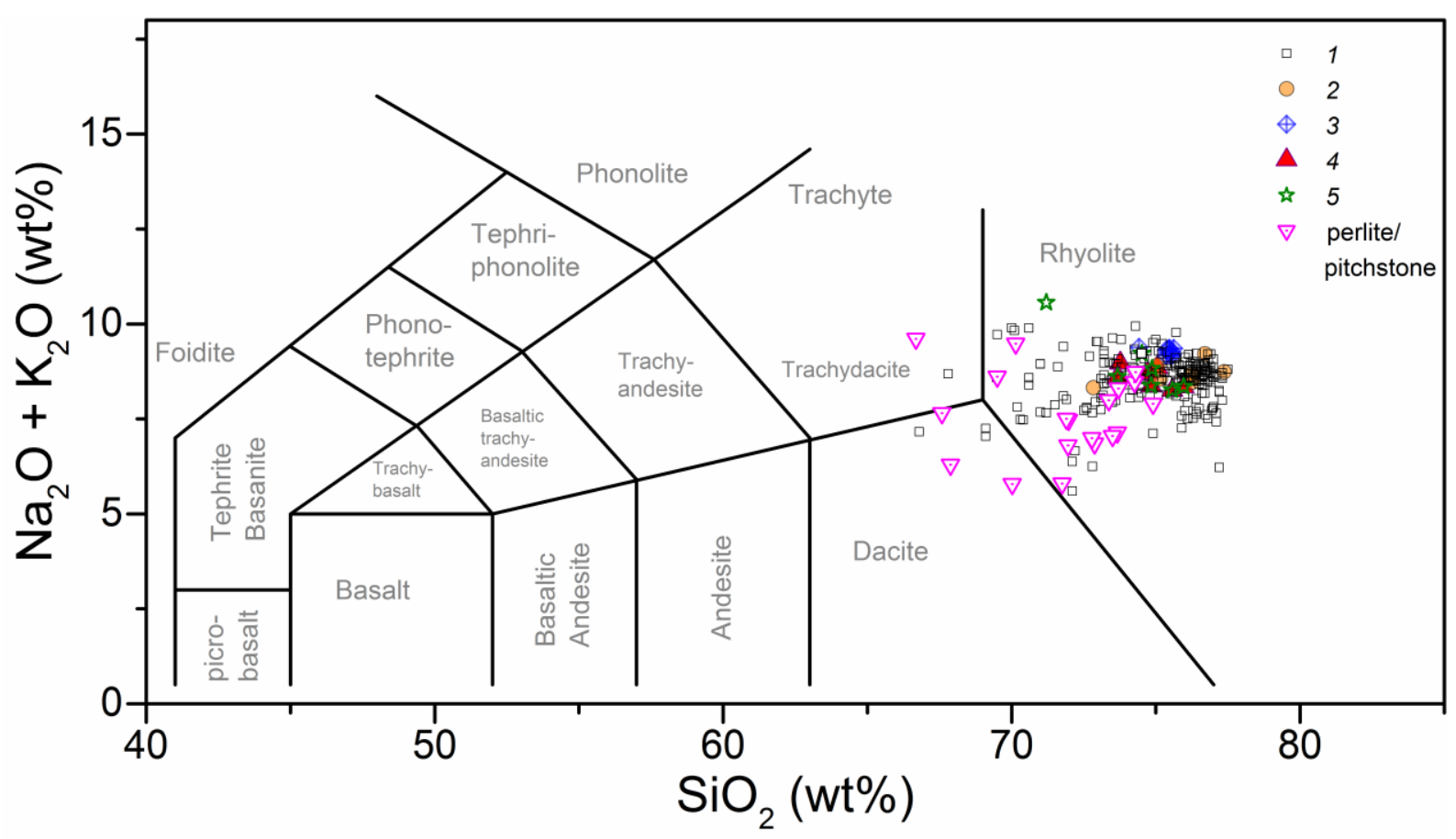

796

Figure 16 - TAS diagram for obsidians, perlites and pitchstones. Obsidian Data for 1) subalkalic silicic obsidians [137]; 2) from [151]; 3) from [152]; 4) from [153] and 5) from [147]. See also Table 1.

pumice is usually considered to be foamed obsidian, and often has water contents similar to that of perlite glasses [15]. A beautiful example for a combined obsidian-pumice deposit can be found at the Rocche Rosse on Lipari Island (I).

Usually pumice samples have pale colors that range from white, grey or blue, to darker colors green-brown or black, depending on the presence/amount of iron. The samples are highly vesiculated with porosity up to $\sim 90 \%$, with the remaining solid part being mainly amorphous. As comparison, the volcanic scoria is less vesiculated (denser), thus it sinks rapidly, whereas pumice samples float on water. Bubbles form a percolating network at porosities between 30-80 vol.\%, depending on melt viscosity, crystallinity, magnitude of shear, and bubble expansion rate [154-157]. Several studies have been done in order to explain the absence of vesicles in obsidian and thus, to provide insights on the change in eruptive behaviour (from explosive to effusive) in silicic volcanic systems (e.g. [157]). 


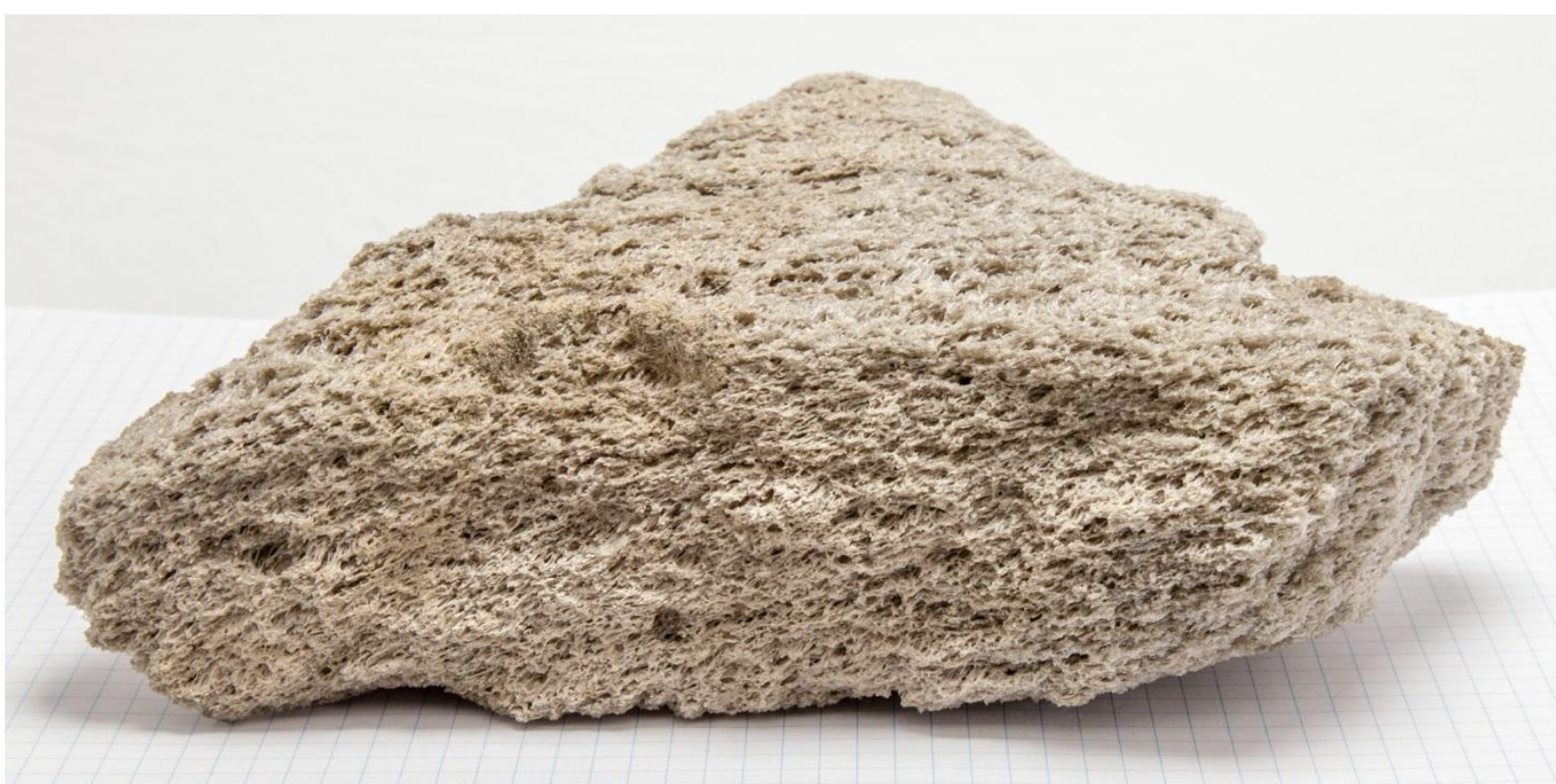

Figure 17 - Photograph of a pumice specimen from Glass Mountain (USA). The sample has the typical highly vesicular irregular texture. Image copyright: D.R. Neuville (square dimension=5mm). growth (zeolites). 
occur in glassy felsic materials [160]. Usually there are several polymineralic aggregates, such as intergrowths of quartz, feldspar and magnetite. The formation conditions of spherulitic textures and the kinetics of spherulite growth in natural silicate are still much debated. E.g. Castro et al. [161] determined the kinetics of spherulite growth in Island obsidians, and the water diffusion modeling yields spherulite growth rates of a few tenths to hundredths of a millimeter per day, depending on temperature [161]. Watkins et al. [162] found that spherulites can grow on the order of days to months at temperatures above the glass transition temperature. Arzilli et al. [160] by using several techniques demonstrated that the development of spherulites is dominated by heterogeneous nucleation and the growth can occur in a short time in water saturated trachytic melts, reaching $400 \mu \mathrm{m}$ diameter in a few hours [160].

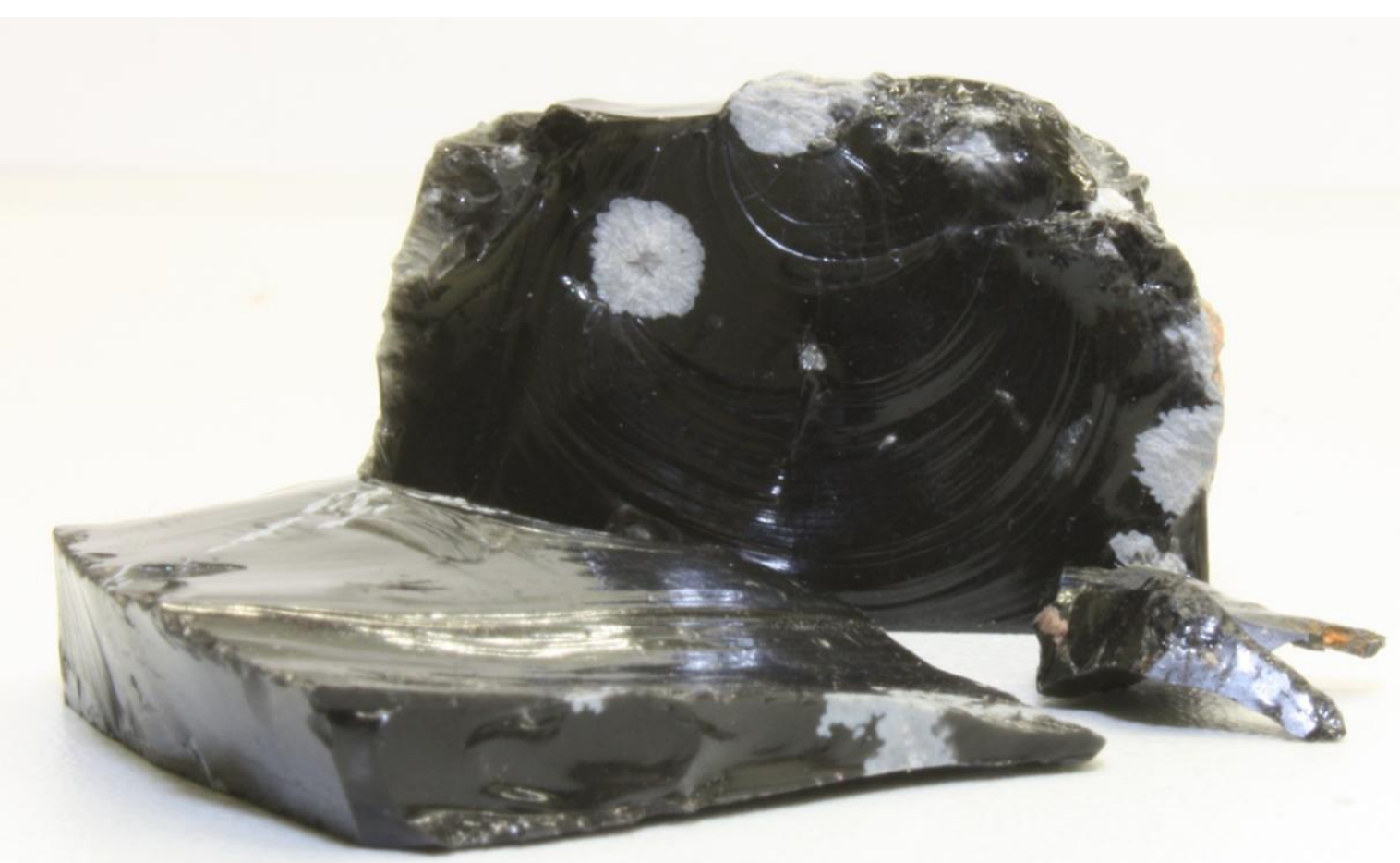

Figure 18 - Photograph of spherulitic obsidians (length $\sim 4 \mathrm{~cm}$; unknown locality). Spherulites are distributed homogeneously all over the samples with size ranging from 3.0 to $8.0 \mathrm{~mm}$. Image copyright: M.R. Cicconi 


\section{ARTIFICIAL PUMICE: FOAM GLASS}

Natural pumice was in Roman time - and still is - largely used for construction materials. For instance, Erdogan et al. [163] report the production of lightweight concrete with economic and environmental advantages by using colemanite (a borate mineral) and pumice materials. Furthermore, in the present time, it is also employed both in industrial and agricultural, as well as in cosmetics, for polishing, abrasive and exfoliating applications (e.g. exfoliating soaps, dental polishing compounds, filtration of drinking water, purifying oils, removing odor).

Artificial pumice (called with different names, such as foam glass or porous glass or cellular glass) can be produced industrially by decompression of volatile -rich melts, where the gas component is ejected in the molten material at an appropriate stage during manufacture [164]. The foam glass has several advantages [164]:

- light weight;

- thermal and acoustic insulating properties;

- resistant to water in both liquid and vapor form;

- non-corrosive

- massive reuse of glass wastes.

Nowadays, being the reduction of energy consumptions one of the main challenges, the reuse of glass wastes for glass foam production enters in the concept of sustainability. For example, Ayadi et al. [165] by using $99 \%$ of glass cullet and only $1 \% \mathrm{CaCO}_{3}$ (as foaming agent), obtained a material with excellent thermal, acoustic and mechanical properties: a 0.5 $\mathrm{g} / \mathrm{cm}^{3}$ dense material characterized by low thermal conductivity $(0.031 \mathrm{~W} / \mathrm{m} * \mathrm{~K})$, and good acoustic properties $(\mathrm{R}=15 \mathrm{~dB})$ [165]. 


\section{4 - Others}

All those glasses that sometimes cannot be classified as volcanic or impact-related, and neither purely "natural" nor of "inorganic-origin" will be grouped under "Others".

\section{1 - Glasses from nuclear explosion: Trinitite}

Detonation of nuclear weapons has created glasses, i.e. from the first atomic bomb test in Alamogorgo (Trinity test, 1945) or from the first underground nuclear explosion (Rainier test, 1957).

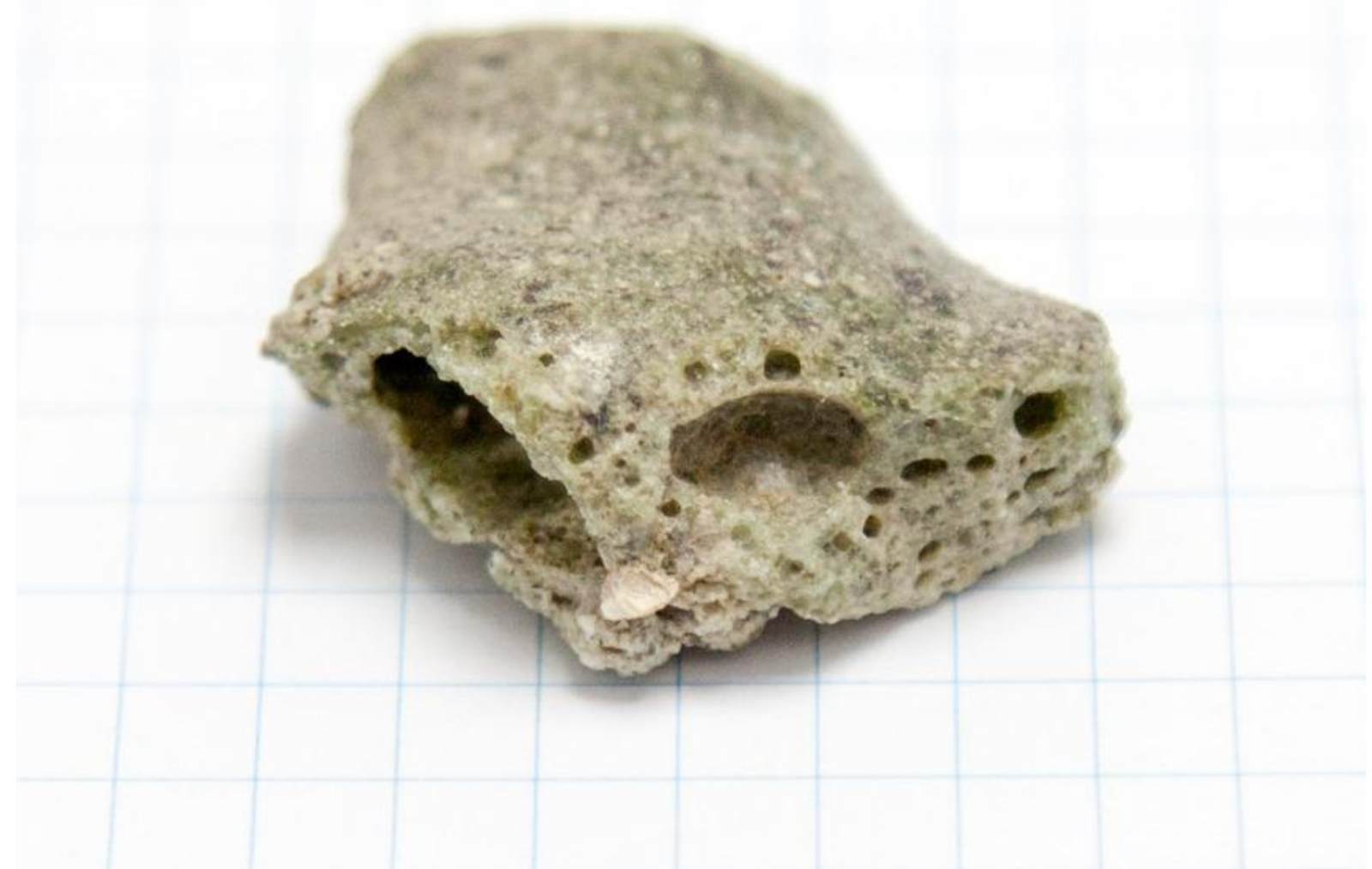

Figure 19 - Glass sample from Trinity site, Tularosa Basin, Alamogorgo (USA). This green trinitite fragment is glassy and vesiculated and is a product of the first atomic bomb blast on July 16, 1945. Image copyright: D.R. Neuville (square dimension=5mm).

The so-called trinitite glasses (first described by Ross [166]) are a record of the first atomic bomb blast on July 16, 1945 (Fig. 19). The resulting fireball that burnt the arkosic sand desert formed a crater glazed with green fused silica sand. Ross [166] studied the optical properties of the amorphous layers and reported the occurrence of two different glasses. The 
first one with higher index of refraction (RI), and the other with a lower index of refraction (close to 1.46), indicating that this material was almost pure silica glass. Ross recognized also the occurrence of gray and red glasses (with dispersed copper). Several years later the early studies of Ross were confirmed and, according to Eby et al. [167], the detonation of the 21 kilotons plutonium bomb, produced four different type of glass: 1) the top part of the layer mainly consist of glassy and vesicular green fragments (Fig. 19), 2) a Cu-rich glass (red trinitite) containing metallic chondrules, (3) scoriaceous trinitite fragments; and (4) ejecta which includes aerodynamically shaped droplets, beads, and dumbbell glasses. The latter were compared to tektite and microtektites and Glass and coauthors [168] described many similarities between tektites and trinitite beads. Moreover, Giuli et al. [169] reported the Fe redox ratio $\left(\mathrm{Fe}^{3+} / \mathrm{Fe}^{2+}\right)$ in a trinitite glass to be close to 0.1 , thus similar to tektites values. Many studies have been done on the radioactive nuclides present in the materials (e.g. [167, 170-172]). Indeed, the migration of actinides at historical test sites has been well studied, since it is closely related to the waste management and to the storage of high-level nuclear waste [173-176].

Eby et al. [177] recently published a detailed mineralogy and petrology study of the different trinitite glasses. The authors pointed out that to explain the physical processes occurring during the glasses formation, two main factors must be considered: the temperature and the duration of high temperatures. Through macroscopic measurements and theoretical calculations, Hermes and Strickfaden [178], estimated backward to the yield, fireball temperature, fireball duration, heat in the rising fireball, and the spread of ejecta from the Trinity test. The authors estimate that the yield of the Trinity event was 9-18 kt, and an average fireball temperature of $8430 \mathrm{~K}$ and a crater depth of approximately $4 \mathrm{ft}$ [178]. Moreover, Hermes and Strickfaden [178] report that the duration of heating was very short $(\sim 3 \mathrm{~s})$ and this could explain why some minerals (zircon and quartz grains) were only partially melted. 
921 features, typical evidence of shock metamorphism in impactites. Based on the mineralogy,

922

923 petrology of the glass samples, and on previous time and temperature estimations, Eby and coauthors concluded that at the instant of detonation, "pressures of at least $8 \mathrm{GPa}$ and temperatures of $>8000 \mathrm{~K}$ occurred in the fireball" $(c f$. [177]).

The study of the first nuclear glass, beside applications for waste management and storage of high-level nuclear waste, has nuclear forensic applications since it provides information on the type of device that was detonated and its origin. Recently, Molgaard and coauthors [179] produced synthetic nuclear glasses, comparable with trinitite glasses, as surrogates that could be used to simulate a variety of scenarios (simulated nuclear event parameters such as, fuel type, weapon yield, and emplacement scenario), and could be used as a tool for developing and validating (nuclear) forensic analysis methods.

\section{2 - Friction melts: Frictionites/Pseudotachylite}

The formation of "friction melts" is associated either with large impact structures, earthquake-generated layers, and very large rock avalanches (e.g. see reviews $[180,181])$. A generic definition for pseudotachylite (generic name for friction melt) is "dense rock produced in the compression and shear associated with intense fault movements, involving extreme mylonitization (i.e. the process of formation of a fine-grained rock produced by bending/internal slip of grains, and recrystallization) and/or partial melting" (from [180]).

Friction melts (and especially those with a pumice texture) were first associated exclusively to volcanic origin or to impact events. Differences between impact-related and fault-related pseudotachylites occur in their thickness and their formation history (single-slip event, multiple stick-slip motion) [182]. The exclusive volcanic origin or impact-associated 
origin hypotheses have been both ruled out from the study of pumiceous rocks from Ötz Valley (Köfels landslide, A. [183, 184]). Indeed in the last decades several studies focused on fault related friction melts (fault pseudotachylytes) that form by coseismic high velocity friction (Fig. 20).

Well studied fault pseudotachylites are from giant rockslides in Himalaya (Nepal) and Köfels (Austria). Masch and Preuß [185] report a detailed study of both events and they observed that glass matrix is chemically heterogeneous with schlieren (elongate segregations of mafic minerals), bubbles, and rock relicts from the parent material (partial to almost complete melting of host rocks of granitic to granodioritic composition). Moreover they report the occurrence of glasses with pure quartz, plagioclase and alkali-feldspar compositions. It's worth mentioning that the giant rockslides in the Himalayas (dislocation of $\sim 170 \mathrm{~m}$ ) caused the formation of a homogeneous glassy crust of thickness between $1-3 \mathrm{~cm}$ [185]. Weidinger et al. [186] report a review of 19 basal deposits of giant rockslides and many had both micro-breccias and frictionite melts.

For the formation of fault pseudotachylite, the estimated melting temperatures derived from the mineral geothermometer of microlites (mineral systems used to estimate the temperatures) or from the chemical compositions of matrices (e.g. [187]). Artificial pseudotachylites have been produced by direct high-speed friction experiments (e.g. [182, $187,188])$ and the estimated melt temperatures of natural and experimental pseudotachylytes are in the range of $750-1400^{\circ} \mathrm{C}$. [187]. Heide and Heide [6] in their review report melting temperatures of $1700^{\circ} \mathrm{C}$ because of the presence of lechatelierite inclusions in frictionite melts. 


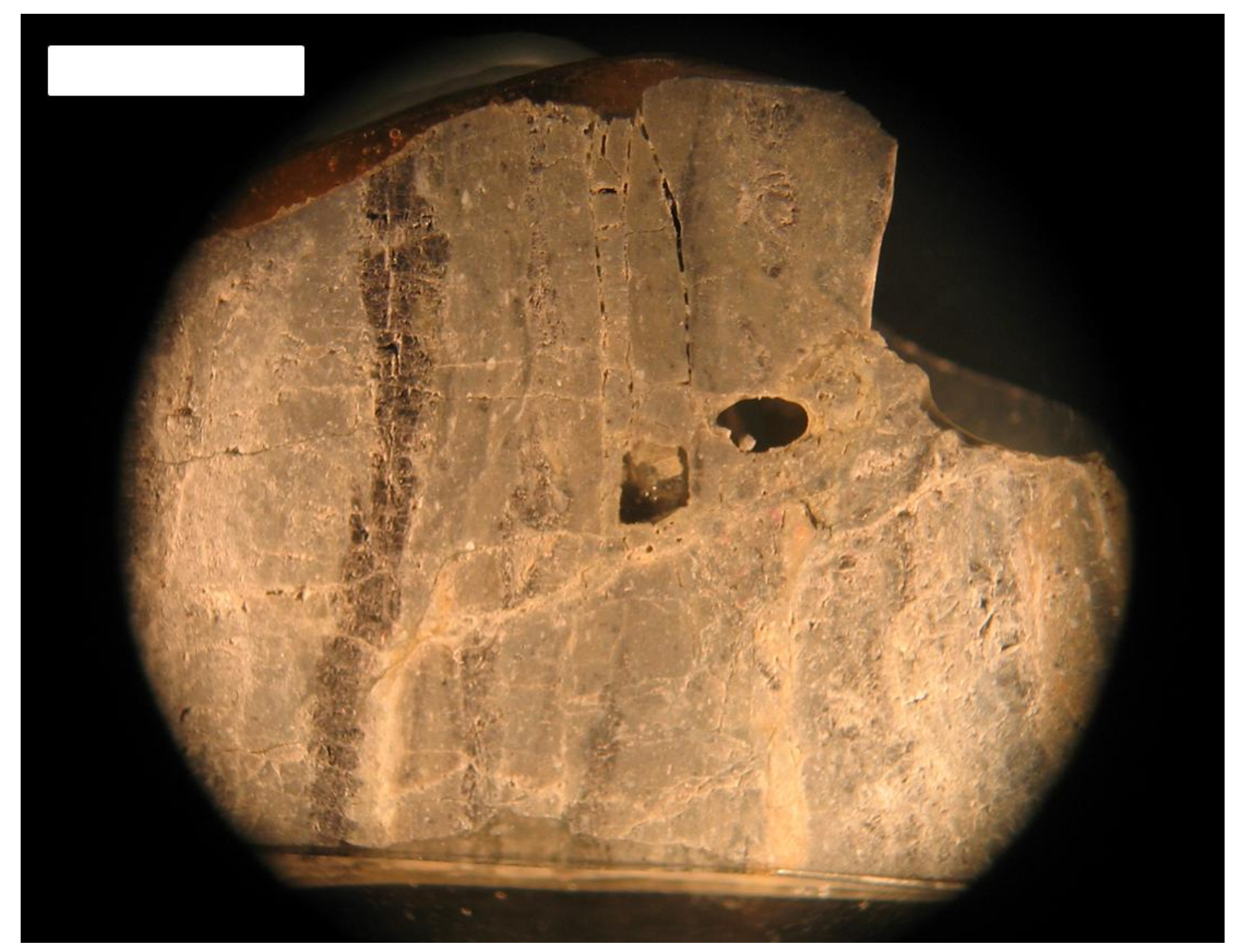

Figure 20 - Microphotography of a pseudotachylite layer (dark layer) from the Nojima fault, 


\section{3 - Bioglasses: amorphous hydrated silica}

Biomineralization processes form biogenic materials that are considered eco-friendly and thus they captured the attention either of organic-/inorganic-chemists and materials scientists. Carbonate and phosphate are the most abundant biominerals in nature. On the other hand, amorphous $\mathrm{SiO}_{2}$, even if less abundant in biomineralizing organisms, has been widely studied (biomimetic studies - the use of models that partially reproduce the natural conditions of biomineral formation. [190])

The low-temperature hydrated variety of silica, opal $\left(\mathrm{SiO}_{2} * \mathrm{nH}_{2} \mathrm{O}\right)$, is a biomineral. Opal is composed of differing amounts and arrangements of structural units of amorphous $\mathrm{SiO}_{2}$, water, and the quartz polymorphs: crystobalite, and tridymite [191] and it is possible to distinguish three types:

- opal-C, with cristobalite;

- opal-CT, with cristobalite and tridymite;

- opal-A, X-ray-“amorphous” opal.

Moreover, the amorphous opal-A can be further divided in opal-AN (e.g., hyalite) and opalAG with an amorphous silica gel structure. In a "maturation process" (Ostwald ripening) opals are transformed as follows ([191] and references therein):

$$
\text { Opal-AG } \rightarrow \text { OpalCT } \rightarrow \text { Opal-C } \rightarrow \text { microcrystalline quartz }
$$

$$
\text { frameworks of short chains of } \mathrm{SiO}_{4} \text { tetrahedra, bonded with apical hydroxyls [192]. The most }
$$
studied biomineralized species are fossil diatom frustules and sponge spicule: e.g. [193] report the study of the evolution of biogenic silica produced in marine environments both for fossils and living organisms, and they identify two different networks. The fossils have a highly condensed and well-organized silica network whereas the living diatoms is much less 
condensed, with the silica network suggested to be linked to the bio-organic components of the cell, in agreement with the biosilicification mechanisms [193].

Usually, the production of silica requires high temperatures a/o pressures, a/o extremes $\mathrm{pH}$ ranges. On the other hand, living organisms are able to form silica under ambient

conditions, with low temperatures and pressures and almost neutral $\mathrm{pH}$. Hence, understanding the biosilica formation mechanisms is of high importance for applications [194]. Indeed, the structure and the evolution of diatoms have several implications for Materials science and palaeoenvironmental research, and in the last years many studies have been devoted to biogenic silica. In the following a few examples are provided.

\section{Bio-optical filters/fibers}

Siliceous spicules from siliceous sponges are composed of siliceous layers superposed in a stratified pattern around a central axial filament [cf. 190], and are excellent light transmitters, and very good optical Bandpass filters. Indeed, exclusively wavelengths between $615 \mathrm{~nm}$ and $1310 \mathrm{~nm}$ can pass through these natural spicule fibers [195]. Moreover, [196, 197] demonstrated that some spicules have compositional variations in the glass/organic composite and a variation in the refractive index profile: with a high refractive index in the spicule core and a low refractive index in the outer portion ("cladding”), thus presenting optical properties similar to those of commercial telecommunication fibers [196, 197].

\section{Metal Oxide production}

The enzymes involved in silica formation have attracted increasing attention because of their potential applications in nano-biotechnology and biomedicine [194]. Indeed, these enzymes, at low temperature and near neutral $\mathrm{pH}$, are also able to catalyze nanoparticles of metal oxides, such as $\mathrm{TiO}_{2}, \mathrm{ZrO}_{2}$, nanocrystalline $\mathrm{Ga}_{2} \mathrm{O}_{3}, \mathrm{GaOOH}$, and also nanocrystalline Perovskite-like Barium Oxofluorotitanate $\left(\mathrm{BaTiOF}_{4}\right)$ [194, 198, 199]. 
1023

1024

1025

1026

1027

1028

1029

1030

1031

1032

1033

1034

1035

1036

1037

1038

1039

1040

1041

1042

1043

1044

1045

1046

\section{Insights into the structure and properties of glasses}

This section is an attempt to highlight the structure and the physical properties of natural glasses. Natural glasses, being a multicomponent system, require a deep understanding of many factors, thus the understanding of the evolution of natural glasses must be considered an interdisciplinary problem.

\section{Physical properties of silicate glasses/melts}

When talking about the physical properties of magma, one of the most important parameters is the viscosity $(\eta)$, i.e. the measure of a fluid's resistance to flow. It controls magma flow rates, rates of volatiles exsolution, rates of diffusion and crystal growth and volcano morphology. Depending on the bulk chemistry we have a wide range of viscosities, as reported in Figure 21, which shows the variation of the viscosity against the reciprocal temperature for a pure silica glass $\left(\mathrm{SiO}_{2}\right)$ and some glasses with mineral compositions of three tectosilicate and one pyroxene compositions (respectively, $\mathrm{Ab}=\mathrm{NaAlSi}_{3} \mathrm{O}_{8}, \mathrm{Or}=\mathrm{KAlSi}_{3} \mathrm{O}_{8}$, $\left.\mathrm{An}=\mathrm{CaAl}_{2} \mathrm{Si}_{2} \mathrm{O}_{8}, \mathrm{Wo}=\mathrm{CaSiO}_{3}\right)$. Nevertheless for a constant composition, there are rapid variations in viscosity when crystals form and/or gas bubbles exsolve: e.g. the viscosity of basaltic melts varies from $<10^{2} \mathrm{~Pa}^{*} \mathrm{~s}$ to $>10^{4} \mathrm{~Pa}^{*} \mathrm{~s}$ for Hawaiian to Plinian eruptions, respectively ([6] and references therein).

The rheology of an obsidian flow is a key parameter governing the textural and structural evolution in obsidian flows. Rhyolitic magmas have a greater melt viscosity due to the high silica content, with respect to basaltic melts (Fig. 21a). Viscosity of rhyolitic magma ranges from $10^{8}$ to $10^{11} \mathrm{~Pa}^{*} \mathrm{~s}$ at temperatures of $700-750^{\circ} \mathrm{C}$, though viscosity strongly decreases with increasing volatile content (e.g. $\left.\mathrm{H}_{2} \mathrm{O}, \mathrm{CO}_{2}\right)$. 
redox conditions, can provide insights on their thermal history. Figure $21 \mathrm{~b}$ shows the

variation of the viscosity $(\eta)$ against the reciprocal temperature for a moldavite (mol) and an

Australasian tektite (chi). These tektites are highly polymerized glasses and the measurements

show the very high viscosities of these glasses, and their nearly Newtonian behaviour (Fig.

21b). It is interesting to notice that the Australasian tektite has a viscosity an order of
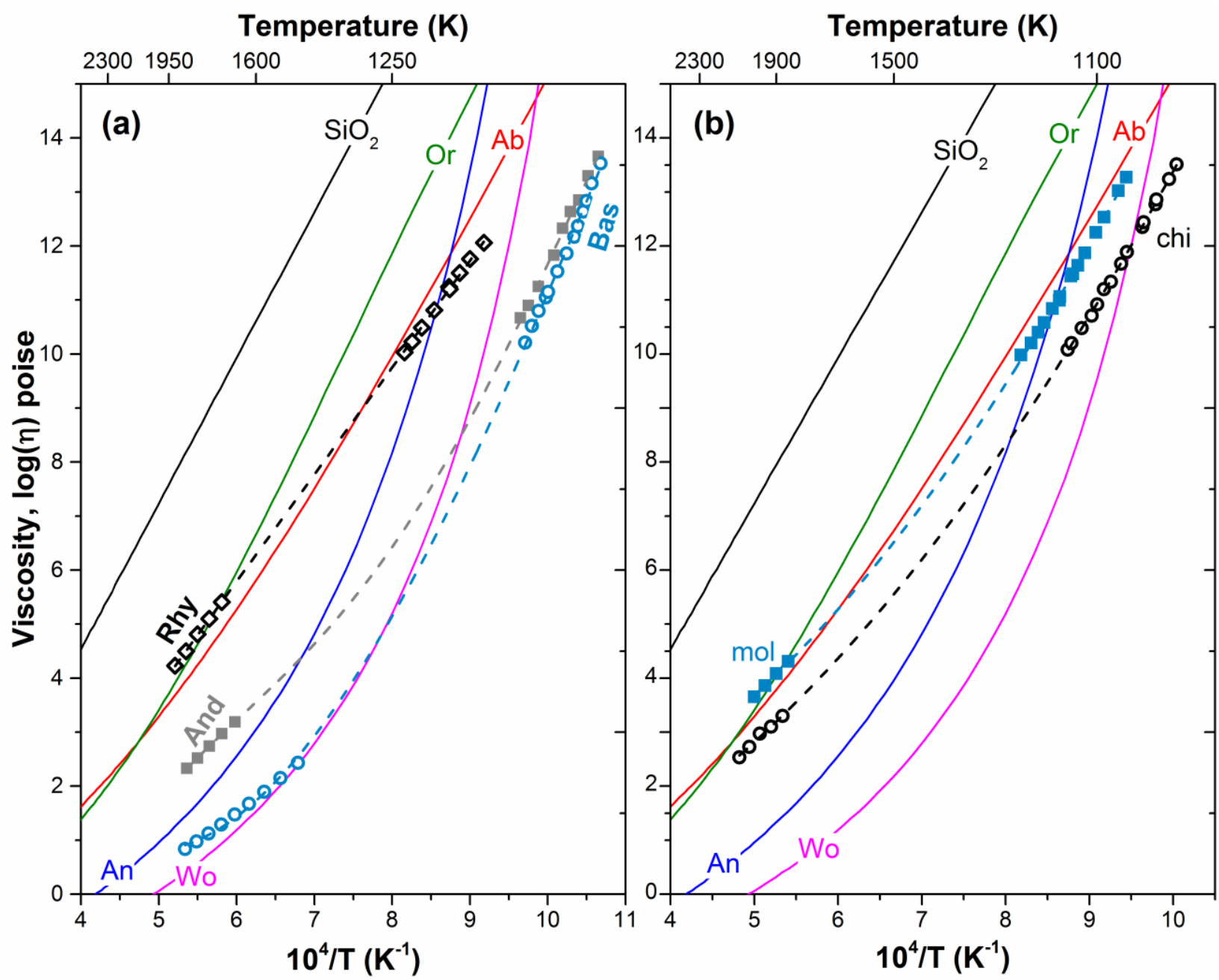

Figure 21 - Low- and high-temperature measured values of viscosity for $\mathrm{SiO}_{2}$, tectosilicates ( $\mathrm{Ab}$, An and Or) and wollastonite (Wo) melts as a function of reciprocal temperature. (a) The 
tektite (chi) are reported as symbols. Lines are only guides for the eyes. Data in Tab. 2 and from [200]. Viscosity measurements were obtained following [201].
To clarify the nature of natural glasses, beside physical properties and redox conditions, it would be helpful to understand the evolution of glass structure upon cooling. The glass properties depend on the process by which it is formed, and close to Tg chemical/ physical properties are extremely sensitive to temperature [202]. For example, in silica this dependence can be well-represented as Arrhenian behaviour (exhibiting approximate linearity) and the liquid is called "strong". On the other hand, a liquid is called "fragile", where the fragility reflects what degree the temperature dependence of the viscosity deviates from Arrhenian behavior. The glass transitions of the two tektites considered here (taken for $\left.\log \eta=12 \mathrm{~Pa}^{*} \mathrm{~s}\right)$ are 1014 and $1070 \mathrm{~K}$, respectively for chi and mol and by using the Angell plot [203] it is possible to do a Tg-scaled Arrhenius ( $\mathrm{Tg} / \mathrm{T}$ ) representation of liquid viscosities (Fig. 22).

Strong liquids, such as $\mathrm{SiO}_{2}$, exhibit Arrhenius behaviour, indicative of a temperatureindependent activation energy [202]. Both moldavite (mol) and Australasian (chi) tektites show a nearly linear behaviour, and thus they can be considered as strong liquids. 


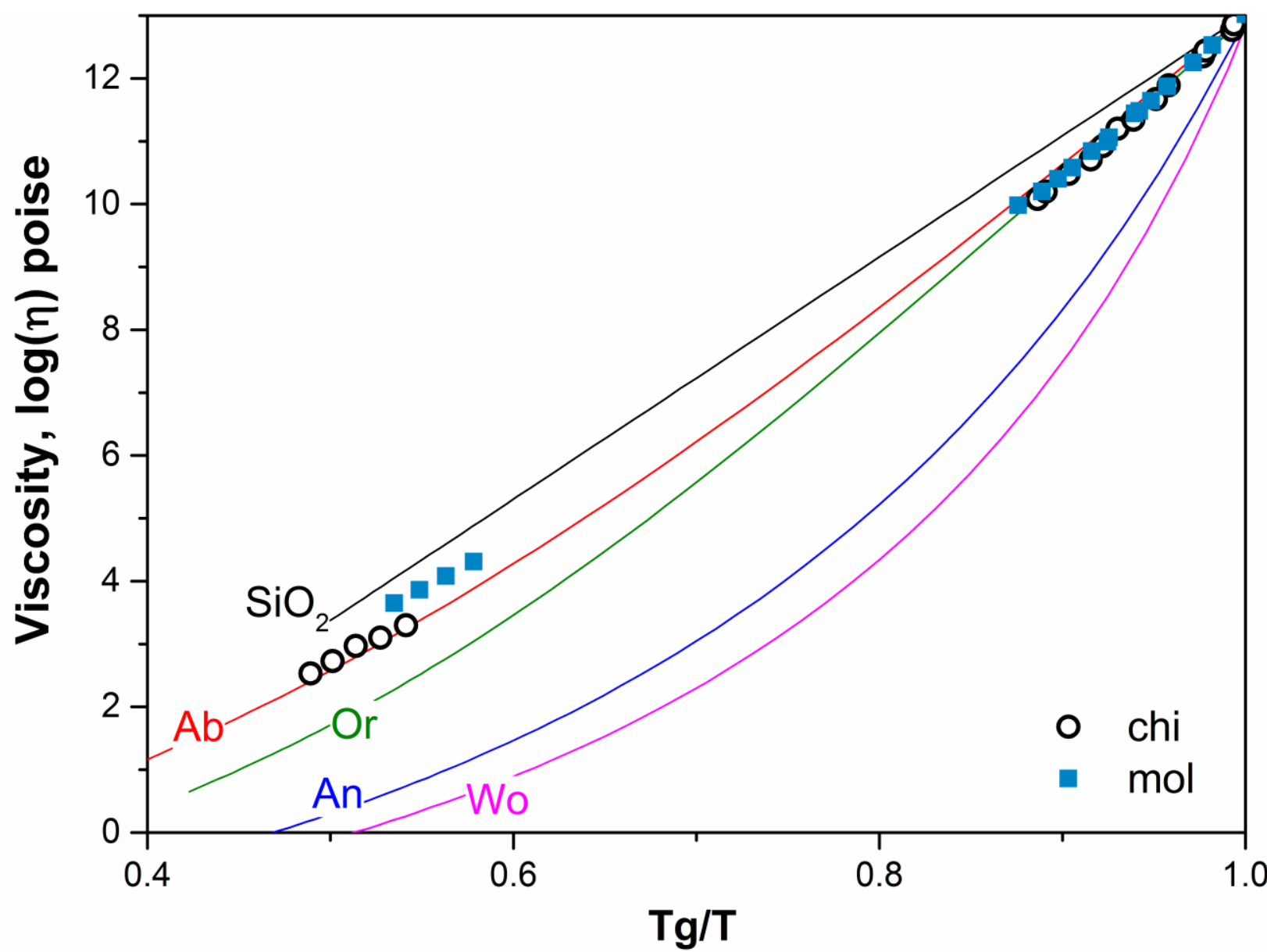

Figure 22 - Tg-scaled Arrhenius representation of liquid viscosities showing Angell's strongfragile pattern. Both tektites, mol and chi, exhibit approximate linearity, and thus a nearly Arrhenian behaviour.

\section{Structure of silicate glasses}

The knowledge of the structure of silicate melt/glass, along with its composition- and

temperature-dependence is crucial to explain many properties of silicate systems. In the

literature there are several investigations on silicate glasses structure, and many studies (e.g.

[204-206]) refer to the "stuffed tridymite" model proposed by Taylor and Brown [207].

Based on X-ray radial distribution analysis of glasses in the system $\mathrm{SiO}_{2}$ - $\mathrm{Ab}$-Or, Taylor and

Brown [207] found several similarities and suggested a stuffed tridymite-like structure for anhydrous Si-rich melts. This model is similar to that proposed by Konnert et al. [208], where silica glasses have a tridymite-like bonding topology based on six-membered rings of $\mathrm{SiO}_{4}$ tetrahedra (cf. Taylor and Brown [207]). Wright et al. [209] made distinctions between silica 
(fulgurite) and silicate glasses (obsidian and tektite) based on neutron diffraction measurements. Okuno et al. [210] studied molten and untreated obsidian and also found that the basic structures of samples may be explained by the "stuffed tridymite" model. Heide and co-workers [211] studied obsidian with wide angle X-ray scattering and concluded that the structure of obsidian is a superposition of quartz- and cristobalite-like structures, in agreement with studies by Wright and Leadbetter [212].

A powerful tool to investigate the structure of silicate glasses is Raman spectroscopy, which provides information on the short- to medium-range order. Raman spectra have been measured on a collection of obsidians, tektites, and related glasses. These spectra will be presented and discussed in terms of the interpretative framework that has developed from studies on synthetic glasses [213].

Raman spectra of silicate glasses consist of three major portions: a high wavenumber region extending from 800 to $1200 \mathrm{~cm}^{-1}$, which provides information on the T-O-T stretching mode (e.g. tetrahedron $\mathrm{T}=\mathrm{Si}, \mathrm{Al}$ ), an intermediate-wavenumber region from 400 to $650 \mathrm{~cm}^{-1}$, which gives information on the T-O-T rocking, bending mode and ring distributions, and a low wavenumber region below $250 \mathrm{~cm}^{-1}$ which provides information on tetrahedral arrangement (see [213] for more details). The high wavenumber region, also referred as $Q$ range, contains polarized bands that have been associated with the symmetric stretching motions of silica tetrahedra. Indeed, the short-range order of silicate glasses can be described through the abundance of the $Q^{n}$ species, where $n$ is the number of bridging oxygens atoms (BO) and $Q$ represents the four-fold coordinated cation - e.g. $\mathrm{Si}, \mathrm{Al}$ (i.e. fully polymerized = $\left.Q^{4}\right)$

A fully-polymerized silica glass $\left(\mathrm{SiO}_{2}-\right.$ Fig. 23$)$ network has only weak high frequency bands (frequency range $\sim 980-1350 \mathrm{~cm}^{-1}$ ), but may be characterized by its strong asymmetric band in the low frequency region $\left(400-500 \mathrm{~cm}^{-1}\right)[214,215]$ and from the well 
pronounced $\mathrm{D}_{1}\left(\sim 490 \mathrm{~cm}^{-1}\right)$ and $\mathrm{D}_{2}\left(\sim 600 \mathrm{~cm}^{-1}\right)$ “defect" lines, associated with the breathing modes of $(\mathrm{SiO})_{4}-$ and $(\mathrm{SiO})_{3}$-rings, respectively (see $\mathrm{SiO}_{2}$ in Fig. 23). By decreasing glass polymerization (e.g. by adding network modifiers), the main peak in the low-frequency region, increases in intensity and shifts to higher wavenumbers, whereas the $Q$-range increases in intensity because other bands, related to different $Q$ species $\left(Q^{3}, Q^{2}\right)$ appear in the $800-1200 \mathrm{~cm}^{-1}$ region [213].

Figure 23 shows the unpolarized Raman spectra of some Si-rich natural glasses in comparison with a synthetic pure $\mathrm{SiO}_{2}$ glass. For some spectra the background was subtracted since there was a strong luminescence both with the excitation lasers at $488 \mathrm{~nm}$ and $532 \mathrm{~nm}$. The shape of the Raman spectra for the natural glasses presented here fit well with those reported in literature (Figs. 23a,b) [124, 132, 147, 216].

The spectra for the fulgurite were collected from the sample reported in Figure 13. A cross section of the specimen was cut and the Raman spectra were collected with an excitation laser at $532 \mathrm{~nm}$. The spectra for the inner glassy portion (fulgurite) and for the outer part (fulgurite2) are reported in Figure 23a. Both spectra resemble that of the pure $\mathrm{SiO}_{2}$ glass, with the typical doublet $440-490 \mathrm{~cm}^{-1}$.

Raman spectra for obsidian samples are reported in Figure 23a. Bellot-Gurlet et al. [147] measured, by Raman spectroscopy, obsidians from the western Mediterranean area. The authors suggest that the detailed analysis of the Raman spectra in the high wavenumber region could be used to distinguish between obsidians originating from Pantelleria and Sardinia and/or Lipari and Palmarola, and thus that Raman spectroscopy could be a complementary technique in archaeological obsidians provenance studies. The obsidian samples, from 3 different locations, shown here have Raman spectra similar to those reported by Bellot-Gurlet et al [147], with the Pantelleria one showing a strong contribution around $975 \mathrm{~cm}^{-1}$. This feature could be ascribed to the high amount of iron in these glasses [217]. 


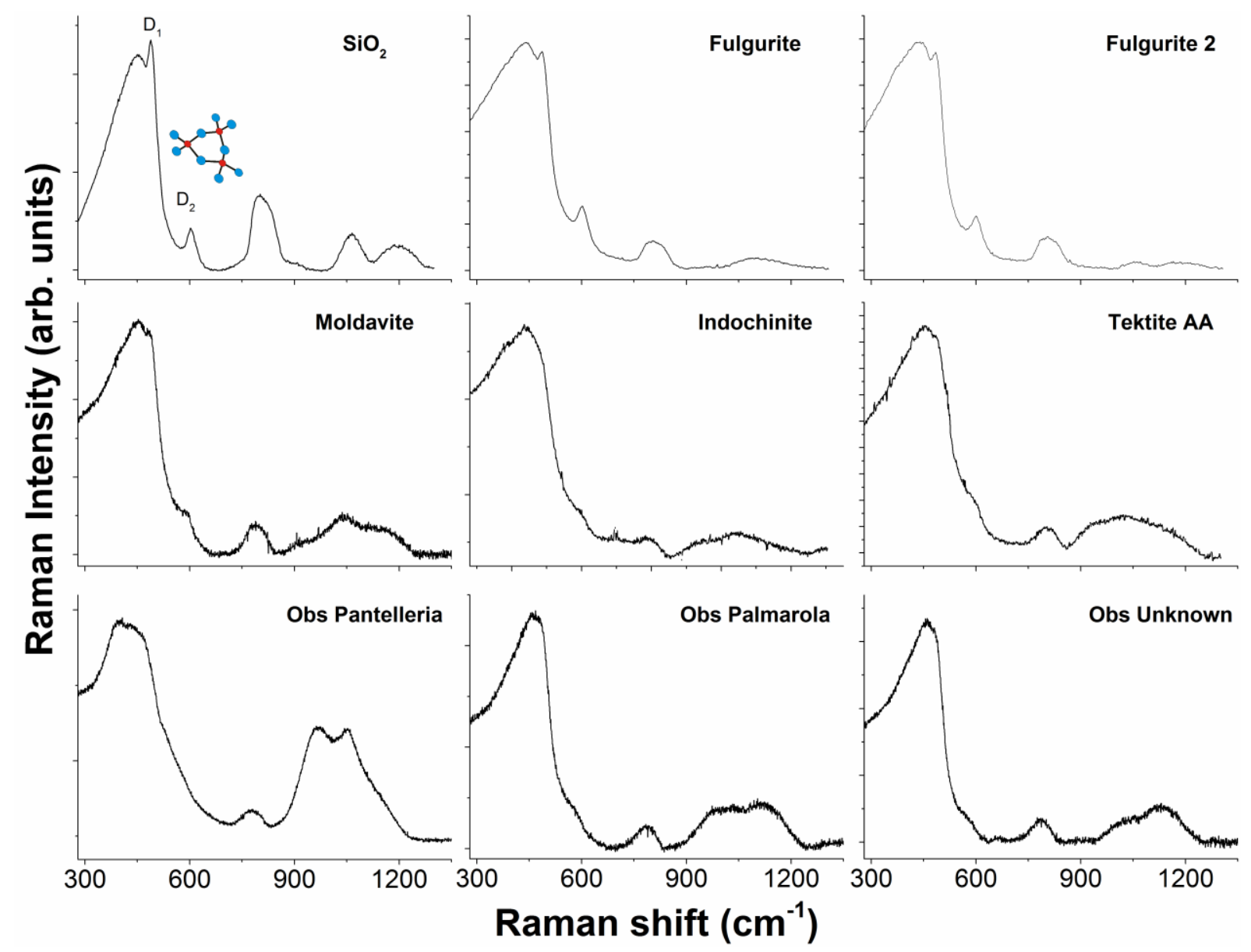

Figure 23a - Raman spectra for some natural silicate glasses and for a pure $\mathrm{SiO}_{2}$ glass in the range $300-1250 \mathrm{~cm}^{-1}$. The shape of the spectra change depending on the polymerization of the glasses, and on the presence/amount of other elements (such as Fe).
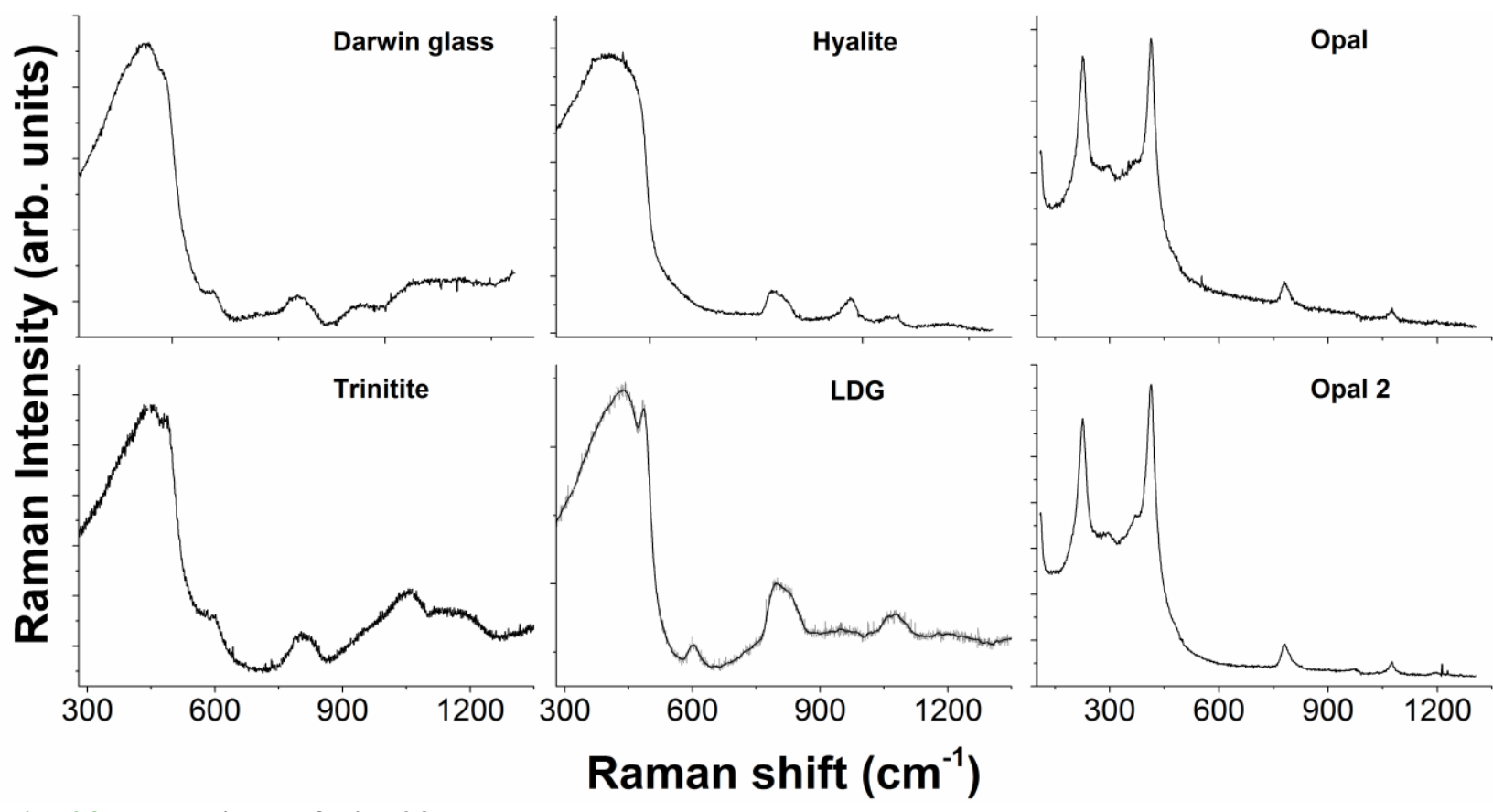

Fig. 23b - continue of Fig. 23a

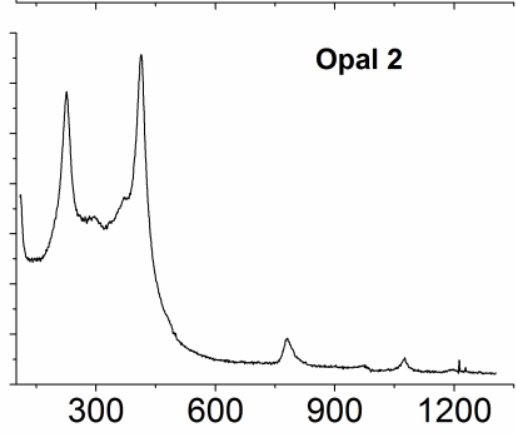



corresponding to the main presence of cristobalite, but also some contributions from a minor presence of tridimyte can be observed, in agreement with the observation done by Ilieva et al. [218]. Indeed, the two sharp peaks respectively at 410 and $226 \mathrm{~cm}^{-1}$ are related to a cristobalite-type atomic arrangement, whereas the small broader contributions at $\sim 350$ and $300 \mathrm{~cm}^{-1}$ are related to a tridymite-type arrangement [218]. Hyalite (Fig. 23b) is the opal-AN form (see section 4.3) and the Raman spectrum highlights the amorphous character, since it presents much broader bands, and no sharp peaks typical of crystalline phases. specimen reported in Figure 19. The Trinitite sample is particularly interesting because it seems to consist of the overlap of a highly polymerized glass and of a more depolymerized glass, since it presents both the characteristic features: D lines and $Q^{2}-Q^{3}$ peaks. temperature in pure $\mathrm{SiO}_{2}$ and they estimated a fictive temperature for $\mathrm{LDG} \sim 1000(+50){ }^{\circ} \mathrm{C}$ and a cooling rate ranging from a few minutes to a few days. However the authors in this early work stated that further work on the subject should be done, especially on the effect of radiation, relaxation time and pressure on the D lines. Champagnon et al. [216] measured Raman spectra for some natural glasses and they show a correlation between the position of the Boson peak (at very low frequency: near $40-60 \mathrm{~cm}^{-1}$ ) and the intensities of the D defect lines. Knowledge of the relationship of the "defect" lines to the Boson peak can help understand the fictive temperature, and in turn, the thermal history. for the study of heterogeneous samples. Many silicic obsidian specimens contain only very small amounts of crystallized phases, even if it is unusual to find glass samples completely 
devoid of crystals, and often the crystalline assemblage includes Ti and Fe oxides. We show an example of Raman mapping done on a spherulitic obsidian sample on the boundary between the crystalline portion (spherulite) and the glass portion (map dimension $\sim 50 \times 30$ micrometers in Fig. 24). In Figure 24 are reported the photo of an obsidian specimen, along with the microscopy image of the mapped portion and some of the Raman spectra collected (7 discrete points) in the range $200-1000 \mathrm{~cm}^{-1}$. All the spectra, and in particular the glass portion has a strong luminescence (likely caused by the presence of transitions elements and REE) at higher wavenumbers (above $1000 \mathrm{~cm}^{-1}$ ). Moving from the spherulite to the glass part, we observed the presence of feldspar minerals (blue and violet points), but also the presence of magnetite/ilmenite, and hematite (orange, green and red points). The spectra for the glassy portion (black and cyan points) have the same contributions observed for the other obsidians. The detection and the study of Fe-Ti oxides is very important, because these oxides are particularly susceptible to variations in the redox conditions.
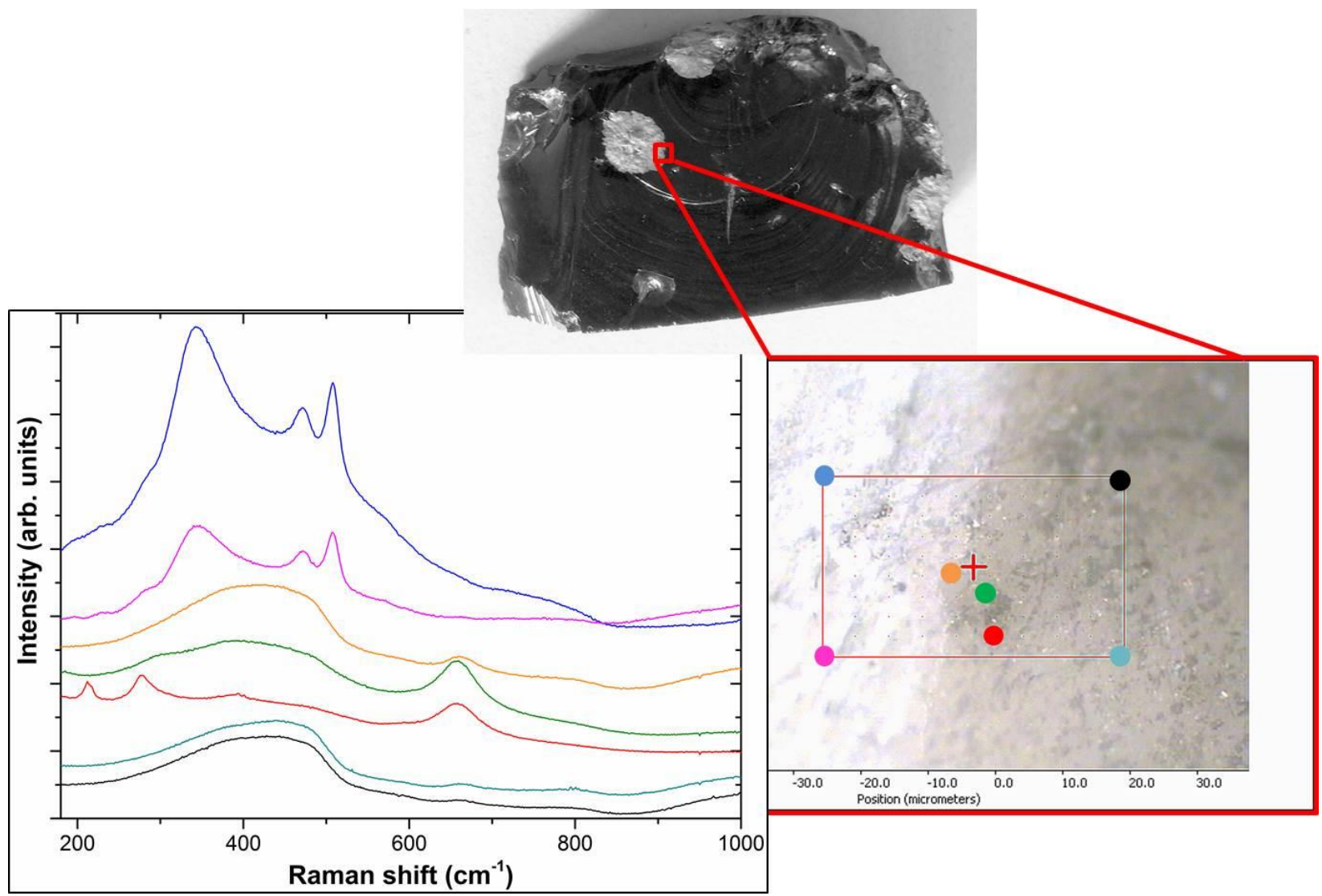
1197 Figure 24 - Photo and light microscopy images of an obsidian specimen and the crystalline 1198 portion (spherulite). The Raman spectra collected both in the glassy and crystalline parts are reported. Beside the glass portion it was possible to identify feldspar minerals (blue and violet points), and magnetite/ilmenite, and hematite (orange, green and red points).

1201

1202 


\section{Redox of natural glass and reduction during high-energy events}

There are many studies (experimental and theoretical) devoted to the understanding of melt/glass redox equilibria since the proportion of each species occurring in the melt is controlled by the bulk composition, temperature, oxygen fugacity, concentration, and presence and amount of volatiles and other redox species. Zotov [206] report a review of the techniques employed to study the structure of natural glasses and of the element-specific spectroscopic methods used to investigate redox and coordination of different major, minor and trace elements in natural volcanic glasses. Most of the studies have been done on the fourth most abundant element in the Earth $(\mathrm{Fe})$ since it is the only major element with more than one electronic configuration - oxidation state and spin state (e.g. see [220-223]).

The data obtained from collision of cosmic objects, or from an airburst, or from lightning (i.e. tektites, impact melts, trinitite, fulgurites) suggest that these events led to the loss of oxygen and consequently to the production of extremely reduced melt phases. Indeed, the high temperatures, speeds, and heating/cooling rates produce exceptional alterations in the involved rocks. Wilding et al. [224] determined the quench rate for distal ejecta (tektites) by calorimetric measurements and reported a cooling rate of a few degree/s at temperature around the glass transition temperature. Wasserman and Melosh [135] report similar values from simulations of simplified systems, and a "blocking temperature" when the evaporation rate of the liquid becomes so slow that there is no time for the phases to equilibrate. If this "blocking temperature" happens at a temperature higher than $2800 \mathrm{~K}, \mathrm{O}_{2}$ gas will be lost from the liquid, leaving the remaining liquid reduced [135].

The knowledge of the fraction of reduced phases (metallic Si, or reduced iron and phosphorous) in glasses, created from such high energy events, could provide constraints for the formation temperatures, and thus to help to shed some light on the major physical and chemical processes occurring. Many early studies on tektites report $\mathrm{Fe}^{3+} / \mathrm{Fe}^{2+}$ values between 
0.02 and 0.23 (e.g. [63, 225-227]). In a study done by Schreiber et al. [227] the authors, by using three different methods, estimated the Fe redox ratio values in Australasian tektites and reported that iron in those glasses to be almost all as $\mathrm{Fe}^{2+}$. Moreover, by remelting the samples at different temperatures and under controlled reducing conditions they tried to constrain the $\mathrm{T}-f \mathrm{O}_{2}$ (oxygen fugacity) regimes for tektites formation. More recent studies on tektites have been carried out by using different techniques: e.g. Mössbauer, ESR (Electron Spin Resonance), XAS (X-ray Absorption Spectroscopy) (e.g. [64-66, 88, 228-230]). As already stressed, except for few early studies, all the investigations done point to Fe in tektites being highly reduced. Only recently, Giuli et al. $[88,231]$ by studying several microtektites from the three different strewn fields, reported the occurrence of higher $\mathrm{Fe}^{3+} / \mathrm{Fe}_{\text {tot }}$ ratios for some North American microtektites. Since alteration of the specimens was ruled out by further analyses (i.e. water content) a different mechanisms was proposed (interaction of melt droplets with a $\mathrm{H}_{2} \mathrm{O}$-rich vapor plume). A slightly different Fe redox state was also reported for MN-type tektites. These glasses have lighter and darker layers, with the lighter ones enriched in $\mathrm{Al}$ and $\mathrm{Fe}$ with respect the darker ones. Giuli et al. [232] report that $\mathrm{MN}$ dark layers are slightly more oxidized respect to the light layers.

An attempt to understand the redox ratio variations for tektites has been done by collecting at high temperatures XAS data at the Fe K-edge (see [233] for details on the experimental procedure). Fe redox kinetics were studied in these highly polymerized glasses/melts from room temperature (RT) to $1680^{\circ} \mathrm{C}$ and the data obtained were compared to the theoretical model of Kress and Carmichael [220]. The XAS data analysis and the Fe redox estimation have been carried out according to the procedure reported in Cicconi et al. [234, 235] for synthetic glasses. At room temperature the indochinite tektite shows, as expected, a $\mathrm{Fe}^{3+} / \Sigma \mathrm{Fe}$ ratio close to $0(\sim 0.05 \pm 0.05$, Fig. 25$)$, in agreement with XAS studies done on several samples by Giuli et al. [64-66]. When heated up at temperature just above $\mathrm{Tg}$ 
$1255(1014 \mathrm{~K})$, the tektite Fe redox ratio increases up to $0.55( \pm 0.05)$ (non equilibrium conditions), 1256 and by further increasing the temperature to $1500 \mathrm{~K}$ and maintaining it as long as needed to 1257 reach the equilibrium, the redox ratio goes up to $\mathrm{Fe}^{3+} / \mathrm{Fetot} \sim 0.7( \pm 0.05)$ (see Fig. 25). By

1258 additionally increasing the temperature, the Fe oxidation state starts to decrease, in good 1259 agreement with the trend suggested by the theoretical model of Kress and Carmichael [220] 1260 (K\&C) for such compositions at ambient pressure (see Fig. 25). Of course, being in an oxygen 1261 depleted atmosphere (reducing conditions) will move the Fe buffer to lower temperatures. 1262 However, to reach this very high amount of reduced iron, and to preserve it even in the glass, 1263 it would be reasonable to consider that the temperatures approached values higher than $2000 \mathrm{~K}$ 1264 and the cooling rate must have been in the order of few $\%$ s. These observations suggest that further studies must be done in order to full 1267 understand the mechanisms occurring during these high-energetic events. Experimental data 1268 on simplified systems along with thermodynamic models could help to understand the main 1269 factors involved. 


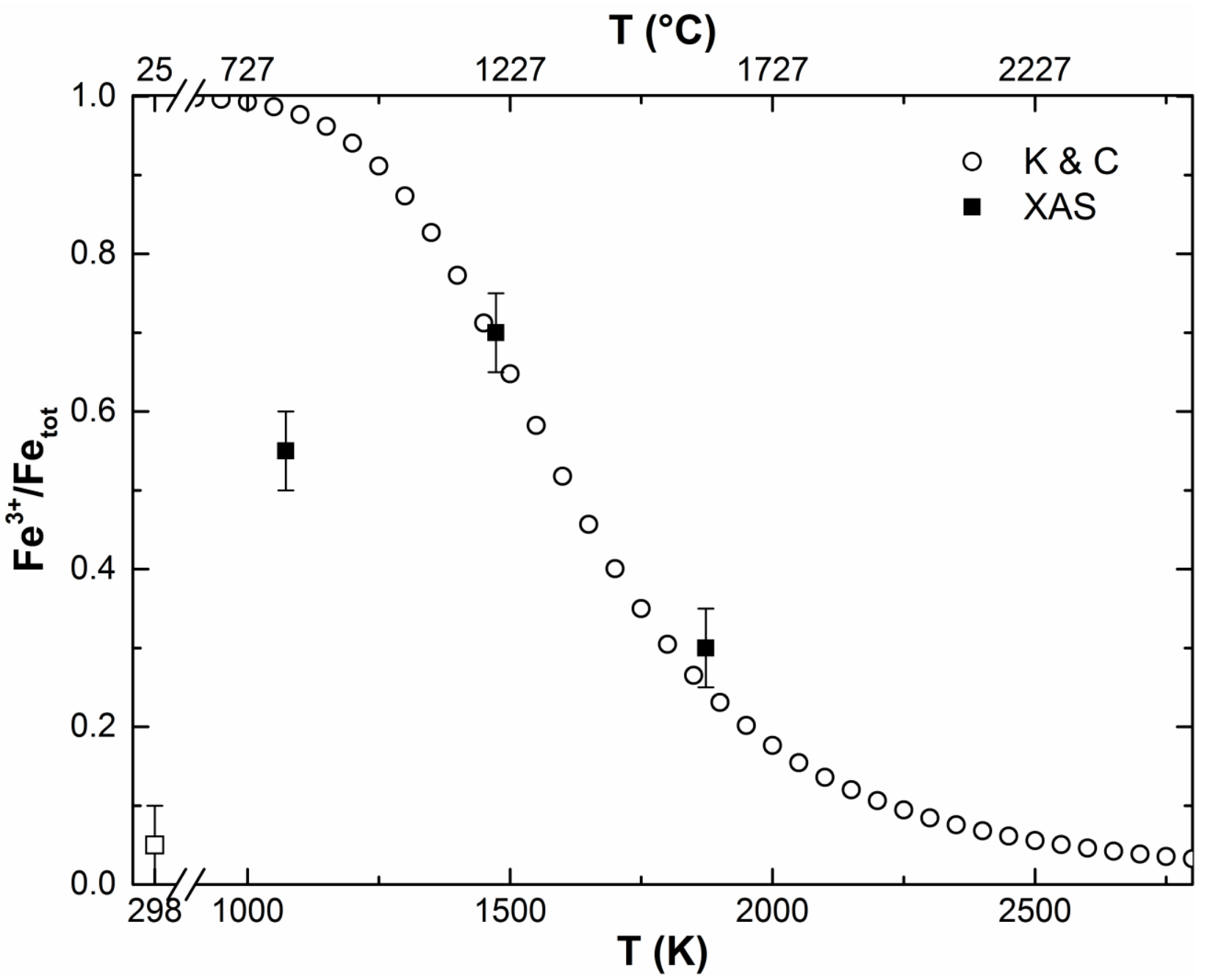

1271

Figure 25 - Fe redox ratio vs T. Empty circles represent the theoretical $\mathrm{Fe}^{3+} / \Sigma \mathrm{Fe}$ values calculate for the indochinite tektite composition by using the model of Kress and Carmichael [220], $\mathrm{K} \& \mathrm{C}$ ). The black squares are the $\mathrm{Fe}^{3+} / \Sigma \mathrm{Fe}$ estimated from the XAS data analysis at high temperatures, whereas the empty square represents the value at room temperature $(\sim 0.05 \pm 0.05)$.

\section{Conclusions and Future Directions}


only in the framework of geosciences (s.l.), but also for many practical uses, or in general to provide useful insights into processes involved in the manufacture of glasses. The key information on natural glasses provided here offers a basis for better synergy

\section{7} between disciplines such as Earth Sciences and Materials Science. Indeed, the cooperation between researches from different "sectors" could provide the ideas needed for moving 1289 forward.

\section{Acknowledgements}

1292 Some of the data here shown have been acquired at FAME beamline and we thanks the 1293 European Synchrotron Radiation Facility (Grenoble, France) for provision of synchrotron 1294 radiation facilities. The authors thank D. de Ligny and G. Henderson for the useful discussions, B. Cochain for help during HT XANES experiments, and J. Stebbins for Libyan Desert glass sample. MRC thanks E. Guillaud for pictures of natural glasses, and S. Wolf for useful discussions on biomimetic materials. DRN thanks J.C. Bouillard, Curator of the Collection de Minéraux University Pierre and Marie Curie, Paris, to provide fulgurite samples. 


\section{References}

1. Weeks RA, Underwood JR, Giegengack R (1984) Libyan Desert glass: A review. J Non Cryst Solids 67:593-619. doi: 10.1016/0022-3093(84)90177-7

2. Delano JW (1986) Pristine lunar glasses: Criteria, data, and implications. J Geophys Res Solid Earth 91:201-213. doi: 10.1029/JB091iB04p0D201

3. Koeberl C (1986) Geochemistry and tektites and impact glasses. Annu Rev Earth Planet Sci 14:323-350. doi: doi:10.1146/annurev.ea.14.050186.001543

4. Glass BP (1990) Tektites and microtektites: key facts and inferences. Tectonophysics 171:393-404. doi: 10.1016/0040-1951(90)90112-L

5. Aboud T (2009) Libyan Desert Glass: has the enigma of its origin been resolved? Phys Procedia 2:1425-1432. doi: 10.1016/j.phpro.2009.11.112

6. Heide K, Heide G (2011) Vitreous state in nature-Origin and properties. Chemie der Erde - Geochemistry 71:305-335. doi: 10.1016/j.chemer.2011.10.001

7. Pasek MA, Block K, Pasek V (2012) Fulgurite morphology: A classification scheme and clues to formation. Contrib to Mineral Petrol 164:477-492. doi: 10.1007/s00410012-0753-5

8. Gill R (2010) Igneous Rocks and Processes - A Practical Guide. Wiley-Blackwell

9. Searle R (2013) Mid-Ocean Ridges. doi: 10.1017/CBO9781139084260

10. Gregg T, Fink J (1995) Quantification of submarine lava-flow morphology through analog experiments. Geology 23:73-76.

11. Byers CD, Muenow DW, Garcia MO (1983) Volatiles in basalts and andesites from the Galapagos Spreading Center, $85^{\circ}$ to $86^{\circ} \mathrm{W}$. Geochim Cosmochim Acta 47:1551-1558. doi: 10.1016/0016-7037(83)90181-3

12. Christie DM, Carmichael ISE, Langmuir CH (1986) Oxidation states of mid-ocean ridge basalt glasses. Earth Planet Sci Lett. doi: 10.1016/0012-821X(86)90195-0

13. Bézos A, Humler E (2005) The Fe3+/??Fe ratios of MORB glasses and their implications for mantle melting. Geochim Cosmochim Acta 69:711-725. doi: 10.1016/j.gca.2004.07.026

14. Frost DJ, McCammon CA (2008) The Redox State of Earth's Mantle. Annu Rev Earth Planet Sci 36:389-420. doi: 10.1146/annurev.earth.36.031207.124322

15. Bouška V (1994) Terrestrial and Lunar, Volcanic and Impact Glasses, Tektites, and Fulgurites. In: Adv. Mineral. Springer Berlin Heidelberg, Berlin, Heidelberg, pp 258265

16. O’Keefe JA (1984) Natural glass. J Non Cryst Solids 67:1-17. doi: 10.1016/00223093(84)90137-6

17. Heiken G (1972) Morphology and petrography of volcanic ashes. Bull Geol Soc Am 83:1961-1988. doi: 10.1130/0016-7606(1972)83[1961:MAPOVA]2.0.CO;2 
18. MacDonald GA (1963) Physical properties of erupting Hawaiian magmas. Bull Geol Soc Am 74:1071-1078. doi: 10.1130/0016-7606(1963)74[1071:PPOEHM]2.0.CO;2

19. Shimozuru D (1994) Physical parameters governing the formation of Pele's hair and tears. Bull Volcanol 56:217-219. doi: 10.1007/BF00279606

20. Moune S, Faure F, Gauthier PJ, Sims KWW (2007) Pele's hairs and tears: Natural probe of volcanic plume. J Volcanol Geotherm Res 164:244-253. doi: 10.1016/j.jvolgeores.2007.05.007

21. Fiore V, Scalici T, Di Bella G, Valenza A (2015) A review on basalt fibre and its composites. Compos Part B Eng 74:74-94. doi: 10.1016/j.compositesb.2014.12.034

22. Dhand V, Mittal G, Rhee KY, Park S-J, Hui D (2015) A short review on basalt fiber reinforced polymer composites. Compos Part B Eng 73:166-180. doi:

10.1016/j.compositesb.2014.12.011

23. Singha K (2012) A Short Review on Basalt Fiber. Int J Text Sci 1:19-28. doi: 10.5923/j.textile.20120104.02

24. Ramachandran BE, Velpari V, Balasubramanian N (1981) Chemical durability studies on basalt fibres. J Mater Sci 16:3393-3397. doi: 10.1007/BF00586301

25. Kyle PR, Moore JA, Thirlwall MF (1992) Petrologic evolution of anorthoclase phonolite lavas at Mount Erebus, Ross island, Antarctica. J Petrol 33:849-875. doi: 10.1093/petrology/33.4.849

26. Kelly PJ, Kyle PR, Dunbar NW, Sims KWW (2008) Geochemistry and mineralogy of the phonolite lava lake, Erebus volcano, Antarctica: 1972-2004 and comparison with older lavas. J Volcanol Geotherm Res 177:589-605. doi: 10.1016/j.jvolgeores.2007.11.025

27. Le Losq C, Neuville DR, Moretti R, Kyle PR, Oppenheimer C (2015) Rheology of phonolitic magmas - the case of the Erebus lava lake. Earth Planet Sci Lett 411:53-61. doi: 10.1016/j.epsl.2014.11.042

28. Kyle PR (1977) Mineralogy and glass chemistry of recent volcanic ejecta from Mt Erebus, Ross Island, Antarctica. New Zeal J Geol Geophys 20:1123-1146. doi: 10.1080/00288306.1977.10420699

29. Friedman I, Long W (1984) Volcanic glasses, their origins and alteration processes. J Non Cryst Solids 67:127-133. doi: 10.1016/0022-3093(84)90144-3

30. Stroncik NA, Schmincke HU (2002) Palagonite - A review. Int J Earth Sci 91:680-697. doi: 10.1007/s00531-001-0238-7

31. Parruzot B, Jollivet P, Rébiscoul D, Gin S (2015) Long-term alteration of basaltic glass: Mechanisms and rates. Geochim Cosmochim 154:28-48.

32. Ewing R (1979) Natural Glasses: Analogues for Radioactive Waste Forms. Sci Basis Nucl Waste Manag 56-78.

33. Chapman N, McKinley I, Smellie J (1984) The potential of natural analogues in assessing systems for deep disposal of high-level radioactive waste. 
34. Ewing R, Jercinovic M (1986) Natural analogues: their application to the prediction of the long-term behavior of nuclear waste forms. MRS Online Proc Libr Arch 84:67.

35. Zielinski R (1980) Stability of glass in the geologic environment: some evidence from studies of natural silicate glasses. Nucl Technol 51:197-200.

36. Malow G, Lutze W, Ewing R (1984) Alteration effects and leach rates of basaltic glasses: Implications for the long-term stability of nuclear waste form borosilicate glasses. J Non Cryst Solids 67:305-321.

37. Byers C, Jercinovic M, Ewing R, Keil K (1984) Basalt glass: an analogue for the evaluation of the long-term stability of nuclear waste form borosilicate glasses. MRS Online Proc. 44:

38. Techer I, Advocat T, Lancelot J, Liotard J-M (2000) Basaltic glass: alteration mechanisms and analogy with nuclear waste glasses. J Nucl Mater 282:40-46. doi: 10.1016/S0022-3115(00)00399-8

39. Berger G, Schott J, Guy C (1988) Behavior of Li, Rb and Cs during basalt glass and olivine dissolution and chlorite, smectite and zeolite precipitation from seawater: Experimental investigations and modelization between $50^{\circ}$ and $300^{\circ} \mathrm{C}$. Chem Geol 71:297-312. doi: 10.1016/0009-2541(88)90056-3

40. Crovisier J-L, Advocat T, Dussossoy J-L (2003) Nature and role of natural alteration gels formed on the surface of ancient volcanic glasses (Natural analogs of waste containment glasses). J Nucl Mater 321:91-109. doi: 10.1016/S0022-3115(03)00206-X

41. Poinssot C, Gin S (2012) Long-term Behavior Science: The cornerstone approach for reliably assessing the long-term performance of nuclear waste. J Nucl Mater 420:182192. doi: 10.1016/j.jnucmat.2011.09.012

42. Brown SM, Grove TL (2015) Origin of the Apollo 14, 15, and 17 yellow ultramafic glasses by mixing of deep cumulate remelts. Geochim Cosmochim Acta 171:201-215. doi: 10.1016/j.gca.2015.09.001

43. Shearer CK, Papike JJ (1993) Basaltic magmatism on the Moon: A perspective from volcanic picritic glass beads. Geochim Cosmochim Acta 57:4785-4812. doi: 10.1016/0016-7037(93)90200-G

44. Ma M, Liu Y, Schmitt R (1982) A chemical study of individual green glasses and brown glasses from 15426-Implications for their petrogenesis. In: Lunar Planet. Sci. Conf. 12th, Houston, TX, March 16-20, 1981, Proceedings. pp 915-933

45. Delano JW, Lindsley DH (1983) Mare glasses from Apollo 17: constraints on the moon's bulk composition. J Geophys Res 88:3. doi: 10.1029/JB088iS01p000B3

46. Longhi J (1987) On the Connection between Mare Basalts and Picritic Volcanic Glasses. J Geophys Res Earth Planets 92:E349-E360. doi: Doi 10.1029/Jb092ib04p0e349

47. Hughes SS, Delano JW, Schmitt RA (1988) Apollo 15 yellow-brown volcanic glass: Chemistry and petrogenetic relations to green volcanic glass and olivine-normative mare basalts. Geochim Cosmochim Acta 52:2379-2391. doi: 10.1016/00167037(88)90295-5 
48. Shearer CK, Papike JJ, Simon SB, Shimizu N, Yurimoto H, Sueno S (1990) Ion microprobe studies of trace elements in Apollo 14 volcanic glass beads: Comparisons to Apollo 14 mare basalts and petrogenesis of picritic magmas. Geochim Cosmochim Acta 54:851-867. doi: 10.1016/0016-7037(90)90378-X

49. Wagner TP, Grove TL (1997) Experimental constraints on the origin of lunar high-Ti ultramafic glasses. Geochim Cosmochim Acta 61:1315-1327. doi: 10.1016/S00167037(96)00387-0

50. Elkins Tanton LT, Van Orman JA, Hager BH, Grove TL (2002) Re-examination of the lunar magma ocean cumulate overturn hypothesis: Melting or mixing is required. Earth Planet Sci Lett 196:239-249. doi: 10.1016/S0012-821X(01)00613-6

51. Krawczynski MJ, Grove TL (2012) Experimental investigation of the influence of oxygen fugacity on the source depths for high titanium lunar ultramafic magmas. Geochim Cosmochim Acta 79:1-19. doi: 10.1016/j.gca.2011.10.043

52. Shearer CK, Hess PC, Wieczorek MA, Pritchard ME, Parmentier EM, Borg LE, Longhi J, Elkins-Tanton LT, Neal CR, Antonenko I, Canup RM (2006) Thermal and Magmatic Evolution of the Moon. In: Rev. Mineral. Geochemistry. pp 365-518

53. Wadhwa M (2008) Redox Conditions on Small Bodies, the Moon and Mars. Rev Mineral Geochemistry 68:493-510. doi: 10.2138/rmg.2008.68.17

54. Herd CDK (2008) Basalts as Probes of Planetary Interior Redox State. Rev Mineral Geochemistry 68:527 LP-553.

55. Papike JJ, Karner JM, Shearer CK (2005) Comparative planetary mineralogy: Valence state partitioning of $\mathrm{Cr}, \mathrm{Fe}, \mathrm{Ti}$, and $\mathrm{V}$ among crystallographic sites in olivine, pyroxene, and spinel from planetary basalts. Am Mineral 90:277-290. doi: 10.2138/am.2005.1779

56. Sato, M., Hickling, N. L., McLane JE (1973) Oxygen fugacity values of Apollo 12, 14, and 15 lunar samples and reduced state of lunar magmas. Proc Lunar Sci Conf 4:1-30. doi: 1973LPSC....4.1061S

57. Fogel RA, Rutherford MJ (1995) Magmatic volatiles in primitive lunar glasses: I. FTIR and EPMA analyses of Apollo 15 green and yellow glasses and revision of the volatileassisted fire-fountain theory. Geochim Cosmochim Acta 59:201-215. doi: 10.1016/0016-7037(94)00377-X

58. Sutton SR, Karner J, Papike J, Delaney JS, Shearer C, Newville M, Eng P, Rivers M, Dyar MD (2005) Vanadium K edge XANES of synthetic and natural basaltic glasses and application to microscale oxygen barometry. Geochim Cosmochim Acta 69:23332348. doi: 10.1016/j.gca.2004.10.013

59. Karner JM, Sutton SR, Papike JJ, Shearer CK, Jones JH, Newville M (2006) Application of a new vanadium valence oxybarometer to basaltic glasses from the Earth, Moon, and Mars. Am Mineral 91:270-277. doi: 10.2138/am.2006.1830

60. Glass BP (1976) High-silica (\&gt;60\%) lunar glasses in an Apollo 14 soil sample: Evidence for silicic lunar volcanism? Earth Planet Sci Lett 33:79-85. doi: $10.1016 / 0012-821 X(76) 90159-X$ 
61. Reimold WU, Jourdan F (2012) \&lt;em\&gt;IMPACT!\&lt;/em\&gt; - BOLIDES, CRATERS, AND CATASTROPHES. Elements 8:19 LP-24.

62. Koeberl C (2013) The Geochemistry and Cosmochemistry of Impacts. In: Treatise Geochemistry Second Ed. pp 73-118

63. Fudali RF, Dyar MD, Griscom DL, Schreiber HD (1987) The oxidation state of iron in tektite glass. Geochim Cosmochim Acta 51:2749-2756. doi: 10.1016/00167037(87)90154-2

64. Giuli G, Pratesi G, Cipriani C, Paris E (2002) Iron local structure in tektites and impact glasses by extended X-ray absorption fine structure and high-resolution X-ray absorption near-edge structure spectroscopy. Geochim Cosmochim Acta 66:43474353. doi: 10.1016/S0016-7037(02)01030-X

65. Giuli G, Eeckhout SG, Cicconi MR, Koeberl C, Pratesi G, Paris E (2010) Iron oxidation state and local structure in North American tektites. Spec Pap Geol Soc Am. doi: $10.1130 / 2010.2465(31)$

66. Giuli G, Cicconi MR, Eeckhout SG, Pratesi G, Paris E, Folco L (2014) Australasian microtektites from Antarctica: XAS determination of the Fe oxidation state. Meteorit Planet Sci 49:696-705. doi: 10.1111/maps.12283

67. O’keefe J (1966) The origin of tektites. Space Sci Rev 6:174-221. doi: 10.1007/BF00222593

68. Glass BP (1969) Chemical composition of Ivory Coast microtektites. Geochim Cosmochim Acta 33:1135-1147. doi: http://dx.doi.org/10.1016/0016-7037(69)90069-6

69. Folco L, D’Orazio M, Tiepolo M, Tonarini S, Ottolini L, Perchiazzi N, Rochette P, Glass BP (2009) Transantarctic Mountain microtektites: Geochemical affinity with Australasian microtektites. Geochim Cosmochim Acta 73:3694-3722. doi: 10.1016/j.gca.2009.03.021

70. Glass BP, Simonson BM (2012) Distal impact ejecta layers: Spherules and more. Elements 8:43-48. doi: 10.2113/gselements.8.1.43

71. Glass BP, Simonson, Bruce M (2013) Distal Impact Ejecta Layers - A Record of Large Impacts in Sedimentary Deposits. doi: 10.1007/978-3-540-88262-6

72. Engelhardt W., Luft E, Arndt J, Schock H, Weiskirchner W (1987) Origin of moldavites. Geochim Cosmochim Acta 51:1425-1443. doi: 10.1016/00167037(87)90326-7

73. Koeberl C (1990) The geochemistry of tektites: an overview. Tectonophysics 171:405422. doi: 10.1016/0040-1951(90)90113-M

74. Deutsch A, Koeberl C (2006) Establishing the link between the Chesapeake Bay impact structure and the North American tektite strewn field: The $\mathrm{Sr}-\mathrm{Nd}$ isotopic evidence. Meteorit Planet Sci 41:689-703. doi: 10.1111/j.1945-5100.2006.tb00985.x

75. Poag CW, Koeberl C, Reimold WU (2004) The Chesapeake Bay Crater. doi: 10.1007/978-3-642-18900-5

76. Stöffler D, Artemieva N a., Pierazzo E (2002) Modeling the Ries-Steinheim impact 
event and the formation of the moldavite strewn field. Meteorit Planet Sci 37:18931907. doi: 10.1111/j.1945-5100.2002.tb01171.x

77. Folco L, Rochette P, Perchiazzi N, D’Orazio M, Laurenzi MAA, Tiepolo M (2008) Microtektites from Victoria Land Transantarctic Mountains. Geology 36:291-294. doi: 10.1130/G24528A.1

78. Folco L, Glass BP, D’Orazio M, Rochette P (2010) A common volatilization trend in Transantarctic Mountain and Australasian microtektites: Implications for their formation model and parent crater location. Earth Planet Sci Lett 293:135-139. doi: 10.1016/j.epsl.2010.02.037

79. Glass BP, Pizzuto JE (1994) Geographic variation in Australasian microtektite concentrations: Implications concerning the location and size of the source crater. $\mathrm{J}$ Geophys Res 99:19075. doi: 10.1029/94JE01866

80. LEE M-Y, WEI K-Y (2000) Australasian microtektites in the South China Sea and the West Philippine Sea: Implications for age, size, and location of the impact crater. Meteorit Planet Sci 35:1151-1155. doi: 10.1111/j.1945-5100.2000.tb01504.x

81. Glass BP, Koeberl C (2006) Australasian microtektites and associated impact ejecta in the South China Sea and the Middle Pleistocene supereruption of Toba. Meteorit Planet Sci 41:305-326. doi: 10.1111/j.1945-5100.2006.tb00211.x

82. Ma P, Aggrey K, Tonzola C, Schnabel C, de Nicola P, Herzog GF, Wasson JT, Glass BP, Brown L, Tera F, Middleton R, Klein J (2004) Beryllium-10 in Australasian tektites: Constraints on the location of the source crater. Geochim Cosmochim Acta 68:3883-3896. doi: 10.1016/j.gca.2004.03.026

83. Glass B (1967) Microtektites in deep-sea sediments. Nat 214:372-374.

84. Glass BP (1978) Australasian microtektites and the stratigraphic age of the australites. Bull Geol Soc Am 89:1455-1458. doi: 10.1130/00167606(1978)89<1455:AMATSA>2.0.CO;2

85. Glass BP (1972) Bottle Green Microtektites. J Geophys Res 77:7057-7064. doi: 10.1029/JB077i035p07057

86. Glass BP, Zwart MJ (1979) North American microtektites in Deep Sea Drilling Project cores from the Caribbean Sea and Gulf of Mexico. Geol Soc Am Bull 90:595. doi: 10.1130/0016-7606(1979)90<595:NAMTID>2.0.CO;2

87. Frey FA (1977) Microtektites: a chemical comparison of bottle-green microtektites, normal microtektites and tektites. Earth Planet Sci Lett 35:43-48. doi: 10.1016/0012821X(77)90026-7

88. Giuli G, Cicconi MR, Eeckhout SG, Koeberl C, Glass BP, Pratesi G, Cestelli-Guidi M, Paris E (2013) Amorphous Materials: Properties, structure, and durability: North American microtektites are more oxidized than tektites. Am Mineral 98:1930-1937. doi: 10.2138/am.2013.4505

89. Koeberl C (1992) Geochemistry and origin of Muong Nong-type tektites. Geochim Cosmochim Acta 56:1033-1064. doi: 10.1016/0016-7037(92)90046-L

90. Artemieva N (2002) Numerical modeling of tektite origin in oblique impacts : 
Implication to Ries-Moldavites strewn field. Bull Czech Geol Surv 77:303-311.

91. Artemieva N, Pierazzo E (2011) The Canyon Diablo impact event: 2. Projectile fate and target melting upon impact. Meteorit Planet Sci 46:805-829. doi: 10.1111/j.19455100.2011.01195.x

92. PIERAZZO E, ARTEMIEVA N, ASPHAUG E, BALDWIN EC, CAZAMIAS J, COKER R, COLLINS GS, CRAWFORD DA, DAVISON T, ELBESHAUSEN D, HOLSAPPLE KA, HOUSEN KR, KORYCANSKY DG, WÜNNEMANN K (2008) Validation of numerical codes for impact and explosion cratering: Impacts on strengthless and metal targets. Meteorit Planet Sci 43:1917-1938. doi: 10.1111/j.19455100.2008.tb00653.x

93. Montanari A, Koeberl C (2000) Impact Stratigraphy. doi: 10.1007/BFb0010313

94. Johnson BC, Melosh HJ (2012) Formation of spherules in impact produced vapor plumes. Icarus 217:416-430. doi: 10.1016/j.icarus.2011.11.020

95. Alvarez LW, Alvarez W, Asaro F, Michel H V. (1980) Extraterrestrial Cause for the Cretaceous-Tertiary Extinction. Science (80- ) 208:1095-1108. doi: 10.1126/science.208.4448.1095

96. Schulte P, Alegret L, Arenillas I, Arz JA, Barton PJ, Bown PR, Bralower TJ, Christeson GL, Claeys P, Cockell CS, Collins GS, Deutsch A, Goldin TJ, Goto K, Grajales-Nishimura JM, Grieve RAF, Gulick SPS, Johnson KR, Kiessling W, Koeberl C, Kring DA, MacLeod KG, Matsui T, Melosh J, Montanari A, Morgan J V., Neal CR, Nichols DJ, Norris RD, Pierazzo E, Ravizza G, Rebolledo-Vieyra M, Reimold WU, Robin E, Salge T, Speijer RP, Sweet AR, Urrutia-Fucugauchi J, Vajda V, Whalen MT, Willumsen PS (2010) The Chicxulub Asteroid Impact and Mass Extinction at the Cretaceous-Paleogene Boundary. Science (80- ) 327:1214-1218. doi: 10.1126/science. 1177265

97. Smit, J. Klaver G (1981) Sanidine spherules at the Cretaceous-Tertiary boundary indicate a large impact event. Nature 292:47-49. doi: 10.1038/292047a0

98. Izett GA (1987) Authigenic â $€^{\mathrm{TM}}$ spherules' in K-T boundary sediments at Caravaca, Spain, and Raton Basin, Colorado and New Mexico, may not be impact derived. Geol Soc Am Bull 99:78-86. doi: 10.1130/0016-7606(1987)99<78:ASIKBS>2.0.CO;2

99. Sigurdsson H, D’Hondt S, Arthur M a., Bralower TJ, Zachos JC, van Fossen M, Channel JET (1991) Glass from the Cretaceous/Tertiary boundary in Haiti. Nature 349:482-487. doi: 10.1038/349482a0

100. Koeberl C (1992) Water content of glasses from the K/T boundary, Haiti: An indication of impact origin. Geochim Cosmochim Acta 56:4329-4332. doi: 10.1016/0016-7037(92)90276-O

101. Koeberl C, Sigurdsson H (1992) Geochemistry of impact glasses from the K/T boundary in Haiti: Relation to smectites and a new type of glass. Geochim Cosmochim Acta 56:2113-2129. doi: 10.1016/0016-7037(92)90333-E

102. Bohor BF (1990) Shock-induced microdeformations in quartz and other mineralogical indications of an impact event at the Cretaceous-Tertiary boundary. Tectonophysics 171:359-372. doi: 10.1016/0040-1951(90)90110-T 
103. Bunch TE, Hermes RE, Moore AMT, Kennett DJ, Weaver JC, Wittke JH, DeCarli PS, Bischoff JL, Hillman GC, Howard GA, Kimbel DR, Kletetschka G, Lipo CP, Sakai S, Revay Z, West A, Firestone RB, Kennett JP (2012) Very high-temperature impact melt products as evidence for cosmic airbursts and impacts 12,900 years ago. Proc Natl Acad Sci 109:E1903-E1912. doi: 10.1073/pnas.1204453109

104. Firestone RB, West A, Kennett JP, Becker L, Bunch TE, Revay ZS, Schultz PH, Belgya T, Kennett DJ, Erlandson JM, Dickenson OJ, Goodyear AC, Harris RS, Howard GA, Kloosterman JB, Lechler P, Mayewski PA, Montgomery J, Poreda R, Darrah T, Hee SSQ, Smith AR, Stich A, Topping W, Wittke JH, Wolbach WS (2007) Evidence for an extraterrestrial impact 12,900 years ago that contributed to the megafaunal extinctions and the Younger Dryas cooling. Proc Natl Acad Sci U S A 104:16016-21. doi: 10.1073/pnas.0706977104

105. Wittke JH, Weaver JC, Bunch TE, Kennett JP, Kennett DJ, Moore AMT, Hillman GC, Tankersley KB, Goodyear AC, Moore CR, Daniel IR, Ray JH, Lopinot NH, Ferraro D, Israde-Alcántara I, Bischoff JL, DeCarli PS, Hermes RE, Kloosterman JB, Revay Z, Howard GA, Kimbel DR, Kletetschka G, Nabelek L, Lipo CP, Sakai S, West A, Firestone RB (2013) Evidence for deposition of 10 million tonnes of impact spherules across four continents 12,800 y ago. Proc Natl Acad Sci 110:E2088-E2097. doi: 10.1073/pnas. 1301760110

106. Surovell TA, Holliday VT, Gingerich JAM, Ketron C, Haynes C V., Hilman I, Wagner DP, Johnson E, Claeys P (2009) An independent evaluation of the Younger Dryas extraterrestrial impact hypothesis. Proc Natl Acad Sci 106:18155-18158. doi: 10.1073/pnas.0907857106

107. Pinter N, Scott AC, Daulton TL, Podoll A, Koeberl C, Anderson RS, Ishman SE (2011) The Younger Dryas impact hypothesis: A requiem. Earth-Science Rev 106:247-264. doi: 10.1016/j.earscirev.2011.02.005

108. Boslough M, Nicoll K, Holliday V, Daulton TL, Meltzer D, Pinter N, Scott AC, Surovell T, Claeys P, Gill J, Paquay F, Marlon J, Bartlein P, Whitlock C, Grayson D, Jull AJT (2012) Arguments and evidence against a Younger Dryas impact event. Geophys Monogr Ser 198:13-26. doi: 10.1029/2012GM001209

109. Van Hoesel A, Hoek WZ, Pennock GM, Drury MR (2014) The younger dryas impact hypothesis: A critical review. Quat Sci Rev 83:95-114. doi: 10.1016/j.quascirev.2013.10.033

110. Reimold WU, Ferrière L, Deutsch A, Koeberl C (2014) Impact controversies: Impact recognition criteria and related issues. Meteorit Planet Sci 49:723-731. doi: 10.1111/maps.12284

111. Bigazzi G, Michele V (1996) New fission-track age determinations on impact glasses. Meteorit Planet Sci 31:234-236. doi: 10.1111/j.1945-5100.1996.tb02017.x

112. Rocchia R, Robin E, Fröhlich F, Meon H, Froget L, Diemer E (1996) L'origine des verres du désert libyque: Un impact météoritique. Comptes rendus l'Académie des Sci Série 2 Sci la terre des planètes 322:839-845.

113. Clayton PA (1934) Silica-Glass from the Libyan Desert. Mineral Mag 23:501-508. doi: 10.1180/minmag.1934.023.144.04 
114. Seebaugh WR, Strauss AM (1984) A cometary impact model for the source of Libyan Desert glass. J Non Cryst Solids 67:511-519. doi: 10.1016/0022-3093(84)90173-X

115. Gomez-Nubla L, Aramendia J, Fdez-Ortiz de Vallejuelo S, Alonso-Olazabal A, Castro K, Zuluaga MC, Ortega LÁ, Murelaga X, Madariaga JM (2017) Multispectroscopic methodology to study Libyan desert glass and its formation conditions. Anal Bioanal Chem 409:3597-3610. doi: 10.1007/s00216-017-0299-5

116. Storzer D, Wagner GA (1977) Fission track dating of meteorite impacts. Meteoritics 12:368-369.

117. Barrat J-AJA, Jahn BMM, Amossé J, Rocchia R, Keller F, Poupeau GRR, Diemer E (1997) Geochemistry and origin of Libyan Desert glasses. Geochim Cosmochim Acta 61:1953-1959. doi: 10.1016/S0016-7037(97)00063-X

118. Storzer D, Koeberl C (1991) Uranium and Zirconium Enrichments in Libyan Desert Glass: Zircon Baddeleyite, and High Temperature History of the Glass. Lunar Planet Sci 22:1345.

119. Swaenen M, Stefaniak EA, Frost R, Worobiec A, Van Grieken R (2010) Investigation of inclusions trapped inside Libyan desert glass by Raman microscopy. Anal Bioanal Chem 397:2659-2665. doi: 10.1007/s00216-009-3351-2

120. Pratesi G, Viti C, Cipriani C, Mellini M (2002) Silicate-silicate liquid immiscibility and graphite ribbons in Libyan desert glass. Geochim Cosmochim Acta 66:903-911. doi: 10.1016/S0016-7037(01)00820-1

121. Giuli G, Paris E, Pratesi G, Koeberl C, Cipriani C (2003) Iron oxidation state in the Ferich layer and silica matrix of Libyan Desert Glass: A high-resolution XANES study. Meteorit Planet Sci 38:1181-1186. doi: 10.1111/j.1945-5100.2003.tb00306.x

122. Lo C-H, Howard KT, Chung S-L, Meffre S (2002) Laser fusion argon-40/argon-39 ages of Darwin impact glass. Meteorit Planet Sci 37:1555-1562. doi: 10.1111/j.19455100.2002.tb00810.x

123. Howard KT (2009) Physical distribution trends in Darwin glass. Meteorit Planet Sci 44:115-129. doi: 10.1111/j.1945-5100.2009.tb00722.x

124. Gomez-Nubla L, Aramendia J, Alonso-Olazabal A, Fdez-Ortiz de Vallejuelo S, Castro K, Ortega LA, Zuluaga MC, Murelaga X, Madariaga JM (2015) Darwin impact glass study by Raman spectroscopy in combination with other spectroscopic techniques. J Raman Spectrosc 46:913-919. doi: 10.1002/jrs.4700

125. Fudali RF, Ford RJ (1979) Darwin Glass and Darwin Crater: a Progress Report. Meteoritics 14:283-296. doi: 10.1111/j.1945-5100.1979.tb00504.x

126. Howard KT, Haines PW (2007) The geology of Darwin Crater, western Tasmania, Australia. Earth Planet Sci Lett 260:328-339. doi: 10.1016/j.epsl.2007.06.007

127. Howard KT (2008) Geochemistry of Darwin glass and target rocks from Darwin Crater, Tasmania, Australia. Meteorit Planet Sci 43:1-21.

128. Essene EJ, Fisher DC (1986) Lightning strike fusion: extreme reduction and metalsilicate liquid immiscibility. Science 234:189-93. doi: 10.1126/science.234.4773.189 
129. Uman MA (1964) The peak temperature of lightning. J Atmos Terr Phys 26:123-128. doi: 10.1016/0021-9169(64)90113-8

130. Krider EP, Dawson GA, Uman MA (1968) Peak power and energy dissipation in a single-stroke lightning flash. J Geophys Res 73:3335-3339. doi: 10.1029/JB073i010p03335

131. Jones BE, Jones KS, Rambo KJ, Rakov VA, Jerald J, Uman MA (2005) Oxide reduction during triggered-lightning fulgurite formation. J Atmos Solar-Terrestrial Phys 67:423-428. doi: 10.1016/j.jastp.2004.11.005

132. Carter EA, Pasek MA, Smith T, Kee TP, Hines P, Edwards HGM (2010) Rapid Raman mapping of a fulgurite. In: Anal. Bioanal. Chem. pp 2647-2658

133. Pasek M, Block K (2009) Lightning-induced reduction of phosphorus oxidation state. Nat Geosci 2:553-556. doi: 10.1038/ngeo580

134. Anderson AE (1925) SAND FULGURITES FROM NEBRASKA THEIR STRUCTURE AND FORMATIVE FACTORS. NEBRASKA STATE MUSEUM Bull. Bull. 7:

135. Wasserman A, Melosh H (2001) Chemical reduction of impact processed materials. Lunar Planet. Inst. ...

136. Rowan LR, Ahrens TJ (1994) Observations of impact-induced molten metal-silicate partitioning. Earth Planet Sci Lett 122:71-88. doi: 10.1016/0012-821X(94)90052-3

137. MacDonald R, Smith RL, Thomas JE (1992) Chemistry of the subalkalic silicic obsidians. Reston, VA

138. Carmichael ISE (1979) Glass and the glassy rocks. In: Evol. igneous rocks. pp 233-244

139. Castro J, Manga M, Cashman K (2002) Dynamics of obsidian flows inferred from microstructures: Insights from microlite preferred orientations. Earth Planet Sci Lett 199:211-226. doi: 10.1016/S0012-821X(02)00559-9

140. Fink JH (1984) Structural geologic constraints on the rheology of rhyolitic obsidian. J Non Cryst Solids 67:135-146. doi: 10.1016/0022-3093(84)90145-5

141. Ericson JE, Makishima A, Mackenzie JD, Berger R (1975) Chemical and physical properties of obsidian: A naturally occurring glass. J Non Cryst Solids 17:129-142.

142. Mameli V, Musinu A, Niznansky D, Peddis D, Ennas G, Ardu A, Lugliè C, Cannas C (2016) Much More Than a Glass: The Complex Magnetic and Microstructural Properties of Obsidian. J Phys Chem C 120:27635-27645. doi: 10.1021/acs.jpcc.6b08387

143. Bellot-Gurlet L, Calligaro T, Dorighel O, Dran JC, Poupeau G, Salomon J (1999) PIXE analysis and fission track dating of obsidian from South American prehispanic cultures (Colombia, Ecuador). Nucl Instruments Methods Phys Res Sect B Beam Interact with Mater Atoms 150:616-621. doi: 10.1016/S0168-583X(98)01089-1

144. Longworth G, Warren SE (1979) The application of M??ssbauer spectroscopy to the characterisation of western mediterranean obsidian. J Archaeol Sci 6:179-193. doi: 10.1016/0305-4403(79)90061-X 
145. Duttine M, Villeneuve G, Poupeau G, Rossi AM, Scorzelli RB (2003) Electron spin resonance of $\mathrm{Fe} 3+$ ion in obsidians from Mediterranean islands. Application to provenance studies. J Non Cryst Solids 323:193-199. doi: 10.1016/S00223093(03)00306-5

146. Milleville A, Bellot-Gourlet L, Champagnon B, Santallier D (2003) La Microspectroscopie Raman pour l'étude des Obsidiennes: Structure, Micro-inclusions et études de provenance? Rev d'Archéométrie 27:123-130. doi: 10.3406/arsci.2003.1048

147. Bellot-Gurlet L, Bourdonnec F-X Le, Poupeau G, Dubernet S (2004) Raman microspectroscopy of western Mediterranean obsidian glass: one step towards provenance studies? J Raman Spectrosc 35:671-677. doi: 10.1002/jrs.1195

148. Ma C, Gresh J, Rossman GR, Ulmer GC, Vicenzi EP (2001) MICRO-ANALYTICAL STUDY OF THE OPTICAL PROPERTIES OF RAINBOW AND SHEEN OBSIDIANS. Can. Mineral. 39:

149. Ma C, Rossman GR, Miller JA (2007) THE ORIGIN OF COLOR IN "FIRE” OBSIDIAN. Can. Mineral. 45:

150. Bagdassarov N, Ritter F, Yanev Y (1999) Kinetics of perlite glasses degassing: TG and DSC analysis.

151. Keller J, Djerbashian R, Karapetian SG, Pernicka E, Nasedkin V (1996) Armenian and Caucasian obsidian occurrences as sources for the Neolithic trade: volcanological setting and chemical characteristics. In: Proc. 29th Symp. Archaeom. pp 69-86

152. Gottsmann J, Dingwell DB (2001) The cooling of frontal flow ramps: A calorimetric study on the Rocche Rosse rhyolite flow, Lipari, Aeolian Islands, Italy. Terra Nov 13:157-164. doi: 10.1046/j.1365-3121.2001.00332.x

153. Tykot RH (2002) Chemical fingerprinting and source tracing of obsidian: The central mediterranean trade in black gold. Acc Chem Res 35:618-627. doi: 10.1021/ar000208p

154. Wright HMN, Weinberg RF (2009) Strain localization in vesicular magma: Implications for rheology and fragmentation. Geology 37:1023-1026. doi: 10.1130/G30199A.1

155. Cabrera A, Weinberg RF, Wright HMN, Zlotnik S, Cas RAF (2011) Melt fracturing and healing: A mechanism for degassing and origin of silicic obsidian. Geology 39:6770. doi: 10.1130/G31355.1

156. Castro JM, Cordonnier B, Tuffen H, Tobin MJ, Puskar L, Martin MC, Bechtel HA (2012) The role of melt-fracture degassing in defusing explosive rhyolite eruptions at volcán Chaitén. Earth Planet Sci Lett 333-334:63-69. doi: 10.1016/j.epsl.2012.04.024

157. Schipper CI, Castro JM, Tuffen H, James MR, How P (2013) Shallow vent architecture during hybrid explosive-effusive activity at Cordón Caulle (Chile, 2011-12): Evidence from direct observations and pyroclast textures. J Volcanol Geotherm Res 262:25-37. doi: 10.1016/j.jvolgeores.2013.06.005

158. Denton JS, Tuffen H, Gilbert JS, Odling N (2009) The hydration and alteration of perlite and rhyolite. J Geol Soc London 166:895-904. doi: 10.1144/0016-76492008007 
159. Vogel W (1994) Glass Chemistry. Springer Berlin Heidelberg

160. Arzilli F, Mancini L, Voltolini M, Cicconi MR, Mohammadi S, Giuli G, Mainprice D, Paris E, Barou F, Carroll MR (2015) Near-liquidus growth of feldspar spherulites in trachytic melts: 3D morphologies and implications in crystallization mechanisms. Lithos 216-217:93-105. doi: 10.1016/j.lithos.2014.12.003

161. Castro JM, Beck P, Tuffen H, Nichols ARL, Dingwell DB, Martin MC (2008) Timescales of spherulite crystallization in obsidian inferred from water concentration profiles. Am Mineral 93:1816-1822. doi: 10.2138/am.2008.2904

162. Watkins J, Manga M, Huber C, Martin M (2009) Diffusion-controlled spherulite growth in obsidian inferred from $\mathrm{H} 2 \mathrm{O}$ concentration profiles. Contrib to Mineral Petrol 157:163-172. doi: 10.1007/s00410-008-0327-8

163. Erdogan Y, Yasar E, Gamage Ranjith P (2016) Obtaining lightweight concrete using colemanite waste and acidic pumice. Physicochem Probl Miner Process. doi: 10.5277/PPMP160103

164. Le Bourhis E (2008) Glass : mechanics and technology. Wiley-VCH Verlag

165. Ayadi A, Stiti N, Boumchedda K, Rennai H, Lerari Y (2011) Elaboration and characterization of porous granules based on waste glass. Powder Technol 208:423426. doi: 10.1016/j.powtec.2010.08.038

166. Ross CS (1948) Optical properties of glass from Alamogordo, New Mexico. Am Mineral 33:360-362.

167. Eby N, Hermes R, Charnley N, Smoliga JA (2010) Trinitite-the atomic rock. Geol Today 26:180-185. doi: 10.1111/j.1365-2451.2010.00767.x

168. Glass BP, Senftle FE, Muenow DW, Aggrey KE, Thorpe AN (1987) Atomic Bomb Glass Beads: Tektite and Microtektite Analogs. In: Second Int. Conf. Nat. Glas. pp 361--369

169. Giuli G, Pratesi G, Eeckhout SG, Koeberl C, Paris E (2010) Iron reduction in silicate glass produced during the 1945 nuclear test at the Trinity site (Alamogordo, New Mexico, USA). In: Geol. Soc. Am. Spec. Pap. Geological Society of America, pp $653-$ 660

170. Atkatz D, Bragg C (1995) Determining the yield of the Trinity nuclear device via gamma-ray spectroscopy. Am J Phys 63:411-413. doi: 10.1119/1.17902

171. Parekh P, Semkow T, Torres M, Haines D (2006) Radioactivity in trinitite six decades later. J Environ Radioact 85:103-120. doi: 10.1016/j.jenvrad.2005.01.017

172. Wallace C, Bellucci JJ, Simonetti A, Hainley T, Koeman EC, Burns PC (2013) A multi-method approach for determination of radionuclide distribution in trinitite. $\mathrm{J}$ Radioanal Nucl Chem 298:993-1003. doi: 10.1007/s10967-013-2497-8

173. Tompson AFB, Bruton CJ, Pawloski GA, Smith DK, Bourcier WL, Shumaker DE, Kersting AB, Carle SF, Maxwell RM (2002) On the evaluation of groundwater contamination from underground nuclear tests. Environ Geol 42:235-247. doi: 10.1007/s00254-001-0493-8 
174. Tompson AFB, Hudson GB, Smith DK, Hunt JR (2006) Analysis of radionuclide migration through a 200-m Vadose zone following a 16-year infiltration event. Adv Water Resour 29:281-292. doi: 10.1016/j.advwatres.2005.02.015

175. Hu QH, Rose TP, Zavarin M, Smith DK, Moran JE, Zhao PH (2008) Assessing fieldscale migration of radionuclides at the Nevada Test Site: "mobile" species. J Environ Radioact 99:1617-1630. doi: 10.1016/j.jenvrad.2008.06.007

176. Pacold JI, Lukens WW, Booth CH, Shuh DK, Knight KB, Eppich GR, Holliday KS (2016) Chemical speciation of U, Fe, and Pu in melt glass from nuclear weapons testing. J Appl Phys. doi: 10.1063/1.4948942

177. Nelson Eby G, Charnley N, Pirrie D, Hermes R, Smoliga J, Rollinson G (2015) Trinitite redux: Mineralogy and petrology. Am Mineral 100:427-441. doi: 10.2138/am2015-4921

178. Hermes RE, Strickfaden WB (2005) A new look at trinitite. Nucl Weapons J 2:2-7.

179. Molgaard JJ, Auxier JD, Giminaro A V., Oldham CJ, Cook MT, Young SA, Hall HL (2015) Development of synthetic nuclear melt glass for forensic analysis. J Radioanal Nucl Chem 304:1293-1301. doi: 10.1007/s10967-015-3941-8

180. Reimold WU, Gibson RL (2005) "Pseudotachylites” in Large Impact Structures. In: Impact Tectonics. Springer-Verlag, Berlin/Heidelberg, pp 1-53

181. Spray JG (2010) Frictional Melting Processes in Planetary Materials: From Hypervelocity Impact to Earthquakes. Annu Rev Earth Planet Sci 38:221-254. doi: 10.1146/annurev.earth.031208.100045

182. Kenkmann T, Hornemann U, Stöffler D (2000) Experimental generation of shockinduced pseudotachylites along lithological interfaces. Meteorit Planet Sci 35:12751290. doi: 10.1111/j.1945-5100.2000.tb01516.x

183. Erismann T, Heuberger H, Preuss E (1977) Der Bimsstein von Koefels (Tirol), ein Bergsturz-?Friktionit? TMPM Tschermaks Mineral und Petrogr Mitteilungen 24:67119. doi: $10.1007 / \mathrm{BF} 01081746$

184. De Blasio FV, Medici L (2017) Microscopic model of rock melting beneath landslides calibrated on the mineralogical analysis of the Köfels frictionite. Landslides 14:337350. doi: 10.1007/s10346-016-0700-z

185. Masch L, Preuss E (1977) Das Vorkommen des Hyalomylonits von Langtang, Himalaya (Nepal). N Jahrb Min, Abh 129:292-311.

186. Weidinger JT, Korup O, Munack H, Altenberger U, Dunning SA, Tippelt G, Lottermoser W (2014) Giant rockslides from the inside. Earth Planet Sci Lett 389:6273. doi: 10.1016/j.epsl.2013.12.017

187. Lin A, Shimamoto T (1998) Selective melting processes as inferred from experimentally generated pseudotachylytes. J Asian Earth Sci 16:533-545. doi: 10.1016/S0743-9547(98)00040-3

188. Spray JG (1987) Artificial generation of pseudotachylyte using friction welding apparatus: simulation of melting on a fault plane. J Struct Geol 9:49-60. doi: 10.1016/0191-8141(87)90043-5 
189. Boullier A-M, Ohtani T, Fujimoto K, Ito H, Dubois M (2001) Fluid inclusions in pseudotachylytes from the Nojima fault, Japan. J Geophys Res 106:21965. doi: 10.1029/2000JB000043

190. Coradin T, Brayner R, Gautier C, Hemadi M, Lopez PJ, Livage J (2007) From Diatoms to Bio-inspired Materials... and Back. In: Proc. 9th Int. Symp. Biominer. Editorial Universitaria, pp 419-430

191. Skinner HCW, Jahren AH (2003) Biomineralization. In: Treatise on Geochemistry. pp $1-69$

192. Fröhlich F (1989) Deep-sea biogenic silica: new structural and analytical data from infrared analysis- geological implications. Terra Nov 1:267-273. doi: 10.1111/j.13653121.1989.tb00368.x

193. Gendron-Badou A, Coradin T, Maquet J, Fröhlich F, Livage J (2003) Spectroscopic characterization of biogenic silica. J Non Cryst Solids 316:331-337. doi: 10.1016/S0022-3093(02)01634-4

194. Schröder HC, Wang X, Tremel W, Ushijima H, Müller WEG (2008) Biofabrication of biosilica-glass by living organisms. Nat Prod Rep 25:455-474. doi: 10.1039/b612515h

195. Müller WEG, Wendt K, Geppert C, Wiens M, Reiber A, Schröder HC (2006) Novel photoreception system in sponges? Biosens Bioelectron 21:1149-1155. doi: 10.1016/j.bios.2005.04.017

196. Sundar VC, Yablon AD, Grazul JL, Ilan M, Aizenberg J (2003) Fibre-optical features of a glass sponge. Nature 424:899-900. doi: 10.1038/424899a

197. Aizenberg J, Sundar VC, Yablon AD, Weaver JC, Chen G (2004) Biological glass fibers: correlation between optical and structural properties. Proc Natl Acad Sci U S A 101:3358-63. doi: 10.1073/pnas.0307843101

198. Brutchey RL, Yoo ES, Morse DE (2006) Biocatalytic Synthesis of a Nanostructured and Crystalline Bimetallic Perovskite-like Barium Oxofluorotitanate at Low Temperature. J Am Chem Soc 128:10288-10294. doi: 10.1021/ja063107g

199. Kisailus D, Choi JH, Weaver JC, Yang W, Morse DE (2005) Enzymatic Synthesis and Nanostructural Control of Gallium Oxide at Low Temperature. Adv Mater 17:314-318. doi: 10.1002/adma.200400815

200. Neuville DR, Courtial P, Dingwell DB, Richet P (1993) Thermodynamic and rheological properties of rhyolite and andesite melts. Contrib to Mineral Petrol 113:572-581. doi: 10.1007/BF00698324

201. Neuville DR (2006) Viscosity, structure and mixing in ( $\mathrm{Ca}, \mathrm{Na})$ silicate melts. Chem Geol 229:28-41. doi: 10.1016/j.chemgeo.2006.01.008

202. Debenedetti PG, Stillinger FH (2001) Supercooled liquids and the glass transition. Nature 410:259-267. doi: 10.1038/35065704

203. Angell CA (1991) Relaxation in liquids, polymers and plastic crystals - strong/fragile patterns and problems. J Non Cryst Solids 131-133:13-31. doi: 10.1016/00223093(91)90266-9 
204. Henderson GS, Fleet ME, Bancroft GM (1984) An x-ray scattering study of vitreous $\mathrm{KFeSi}<$ inf $>3</$ inf $>\mathrm{O}<$ inf $>8</$ inf $>$ and $\mathrm{NaFeSi}<$ inf $>3</$ inf $>\mathrm{O}<$ inf $>8</$ inf $>$ and reinvestigation of vitreous $\mathrm{SiO}<\mathrm{inf}>2</ \mathrm{inf}>$ using quasi-crystalline modelling. J Non Cryst Solids. doi: 10.1016/0022-3093(84)90015-2

205. Deganello G, Liotta L, Longo A, Martorana A, Yanev Y, Zotov N (1998) Structure of natural water-containing glasses from Lipari (Italy) and Eastern Rhodopes (Bulgaria): SAXS, WAXS and IR studies. J Non Cryst Solids 232:547-553. doi: 10.1016/S00223093(98)00429-3

206. Zotov N (2003) Structure of natural volcanic glasses: Diffraction versus spectroscopic perspective. In: J. Non. Cryst. Solids. pp 1-6

207. Taylor M, Brown GE (1979) Structure of mineral glasses-I. The feldspar glasses NaAlSi3O8, KAlSi3O8, CaAl2Si2O8. Geochim Cosmochim Acta 43:61-75. doi: 10.1016/0016-7037(79)90047-4

208. Konnert JH, Karle J, Ferguson GA (1973) Crystalline Ordering in Silica and Germania Glasses. Science (80-. ). 179:

209. Wright AC, Desa JAE, Weeks RA, Sinclair RN, Bailey DK (1984) Neutron diffraction studies of natural glasses. J Non Cryst Solids 67:35-44. doi: 10.1016/00223093(84)90139-X

210. Okuno M, Iwatsuki H, Matsumoto T (1997) Structural analysis of an obsidian by X-ray diffraction method. Eur J Mineral 8:1257-1264. doi: 10.1127/ejm/8/6/1257

211. Heide G, Müller B, Kloess G, Moseler D, Frischat GH (2003) Structural classification of natural non-crystalline silicates. J Non Cryst Solids 323:68-71. doi: 10.1016/S00223093(03)00286-2

212. Wright AC, Leadbetter AJ (1976) Diffraction studies of glass structure. Phys Chem Glas 17:122-145.

213. Neuville DR, de Ligny D, Henderson GS (2014) Advances in Raman Spectroscopy Applied to Earth and Material Sciences. Rev Mineral Geochemistry. doi: 10.2138/rmg.2013.78.13

214. McMillan P, Piriou B (1982) The structures and vibrational spectra of crystals and glasses in the silica-alumina system. J Non Cryst Solids 53:279-298. doi: 10.1016/0022-3093(82)90086-2

215. McMillan PF (1984) Structural Studies of Silicate Glasses and Melts-Applications and Limitations of Raman Spectroscopy. Am Mineral 69:622-644. doi: 0003004x/84/070E-0622\$0

216. Champagnon B, Panczer G, Chemarin C (1997) Differentiation of natural silica glasses using Raman microspectrometry. Chemie der Erde-Geochemistry 57:290-296.

217. Di Genova D, Morgavi D, Hess K-U, Neuville DR, Borovkov N, Perugini D, Dingwell DB (2015) Approximate chemical analysis of volcanic glasses using Raman spectroscopy. J Raman Spectrosc 46:1235-1244. doi: 10.1002/jrs.4751

218. Ilieva A, Mihailova B, Tsintsov Z, Petrov O (2007) Structural state of microcrystalline opals: A Raman spectroscopic study. Am Mineral 92:1325-1333. doi: 
219. Galeener FL, Geissberger AE, Weeks RA (1984) On the thermal history of Libyan Desert glass. J Non Cryst Solids 67:629-636. doi: 10.1016/0022-3093(84)90179-0

220. Kress VC, Carmichael ISE (1991) The compressibility of silicate liquids containing $\mathrm{Fe} 2 \mathrm{O} 3$ and the effect of composition, temperature, oxygen fugacity and pressure on their redox states. Contrib to Mineral Petrol 108:82-92. doi: 10.1007/BF00307328

221. Ottonello G, Moretti R, Marini L, Vetuschi Zuccolini M (2001) Oxidation state of iron in silicate glasses and melts: A thermochemical model. Chem Geol 174:157-179. doi: 10.1016/S0009-2541(00)00314-4

222. McCammon CA (2005) Mantle oxidation state and oxygen fugacity: Constraints on mantle chemistry, structure, and dynamics. American Geophysical Union, pp 219-240

223. McCammon CA (2006) Microscopic properties to macroscopic behaviour: The influence of iron electronic state. J Mineral Petrol Sci 101:130-144. doi: $10.2465 /$ jmps. 101.130

224. Wilding M, Webb S, Dingwell DB (1996) Tektite cooling rates: Calorimetric relaxation geospeedometry applied to a natural glass. Geochim Cosmochim Acta 60:1099-1103. doi: 10.1016/0016-7037(96)00010-5

225. Schnetzler C, Pinson W (1963) The chemical composition of tektites. In: O'Keefe JA (ed) Tektites. University of Chicago Press, pp 95-129

226. Philpotts J., Pinson W. (1966) New data on the chemical composition and origin of moldavites. Geochim Cosmochim Acta 30:253-266. doi: 10.1016/00167037(66)90001-9

227. Schreiber HD, Minnix LM, Balazs GB (1984) The redox state of iron in tektites. J Non Cryst Solids 67:349-359. doi: 10.1016/0022-3093(84)90160-1

228. Evans BJ, Leung LK (1979) Mössbauer Spectroscopy of Tektites and Other Natural Glasses. Le J Phys Colloq 40:C2-489-C2-490. doi: 10.1051/jphyscol:19792172

229. Dunlap RA (1997) An investigation of Fe oxidation states and site distributions in a Tibetan tektite. Hyperfine Interact 110:217-225. doi: 10.1023/A:1012691820021

230. Rossano S, Balan E, Morin G, Bauer JP, Calas G, Brouder C (1999) 57Fe Mössbauer spectroscopy of tektites. Phys Chem Miner 26:530-538.

231. Giuli G, Eeckhout SG, Cicconi MR, Koeberl C, Glass BP, Pratesi G, Paris E (2008) North-American Microtektites are More Oxidized Compared to Tektites. Large Meteor. Impacts Planet. Evol. IV 1423:

232. Giuli G, Cicconi MR, Trapananti A, Eeckhout SG, Pratesi G, Paris E, Koeberl C (2013) Iron redox variations in Australasian Muong Nong-type tektites. In: 76th Annu. Meteorit. Soc. Meet. p 5246

233. Neuville DR, Hennet L, Florian P, de Ligny D (2014) In situ High-Temperature Experiments. Rev Mineral Geochemistry 78:779-800. doi: 10.2138/rmg.2013.78.19

234. Cicconi MR, Neuville DR, Tannou I, Baudelet F, Floury P, Paris E, Giuli G (2015) 
Letter. Competition between two redox states in silicate melts: An in-situ experiment at the Fe K-edge and Eu L<inf>3</inf>-edge. Am Mineral 100:1013-1016. doi: 10.2138/am-2015-5172

235. Cicconi MR, Giuli G, Ertel-Ingrisch W, Paris E, Dingwell DB (2015) The effect of the $[\mathrm{Na} /(\mathrm{Na}+\mathrm{K})]$ ratio on Fe speciation in phonolitic glasses. Am Mineral 100:1610-1619. doi: 10.2138/am-2015-5155

236. Burkhard DJM (2001) Crystallization and oxidation of Kilauea basalt glass: Processes during reheating experiments. J Petrol 42:507-527 ST-Crystallization and oxidation of Kil. doi: $10.1093 /$ petrology/42.3.507

237. Davis MG, Garcia MO, Wallace P (2003) Volatiles in glasses from Mauna Loa Volcano, Hawai'i: implications for magma degassing and contamination, and growth of Hawaiian volcanoes. Contrib to Mineral Petrol 144:570-591. doi: 10.1007/s00410002-0416-Z

238. Katsura T (1967) Pele's hair as a liquid of Hawaiian tholeiitic basalts. Geochem J 1:157-168. doi: 10.2343/geochemj.1.157

239. Wright TL (1973) Magma mixing as illustrated by the 1959 eruption, Kilauea Volcano, Hawaii. Bull Geol Soc Am 84:849-858. doi: 10.1130/0016-

7606(1973)84<849:MMAIBT>2.0.CO;2

240. Chapman DR, Scheiber LC (1969) Chemical investigation of Australasian tektites. J Geophys Res 74:6737-6776. doi: 10.1029/JB074i027p06737

241. Glass BP, Koeberl C, Blum JD, Senftle F, Izett GA, Evans BJ, Thorpe AN, Povenmire H, Strange RL (1995) A Muong Nong-type Georgia tektite. Geochim Cosmochim Acta 59:4071-4082. doi: 10.1016/0016-7037(95)00290-G

242. Lange JM (1996) Tektite glasses from Lusatia (Lausitz), Germany. Chemie der Erde 56:498-510.

243. Žák K, Skála R, Řanda Z, Mizera J (2012) A review of volatile compounds in tektites, and carbon content and isotopic composition of moldavite glass. Meteorit Planet Sci 47:1010-1028. doi: 10.1111/j.1945-5100.2012.01369.x

244. Giuli G, Eeckhout SG, Paris E, Koeberl C, Pratesi G (2005) Iron oxidation state in impact glass from the K/T boundary at Beloc, Haiti, by high-resolution XANES spectroscopy. Meteorit Planet Sci 40:1575-1580. doi: 10.1111/j.19455100.2005.tb00132.x

245. Koeberl C (1997) Libyan Desert Glass: geochemical composition and origin. In: Proc. Silica '96 Meet. pp 121-131

246. Meisel T, Koeberl C, Ford RJ (1990) Geochemistry of Darwin impact glass and target rocks. Geochim Cosmochim Acta 54:1463-1474. doi: 10.1016/0016-7037(90)90169-L 


\section{Figure captions}

Fig. 1 - Total alkali vs. silica (TAS) diagram for several natural glasses (some of the data and references are reported in Table 1).

Figure 2 - Basaltic glass from French-American Mid-Ocean Undersea Study (FAMOUS) area on the Mid-Atlantic Ridge. Image copyright: D.R. Neuville.

Figure 3 - Reticulite from Erebus volcano. This highly foamed sample is mainly composed of glass. Image copyright: D.R. Neuville (sample dimension 7x6x5cm)..

Fig. 4 - Photograph of Pele's hairs along with few melt droplets. Samples from Hawaiian Islands. Image copyright: D.R. Neuville (square dimension=5mm).

Figure 5 - Bomb sample from Erebus volcano with the surface covered by olive green and black glass with a metallic lustre, and anorthosite crystals. Image copyright: D.R. Neuville (square dimension $=5 \mathrm{~mm}$ ).

Figure 6 - Palagonite specimen. Image copyright: D.R. Neuville.

Figure 7 - Variation of $\mathrm{SiO} 2$ and $\mathrm{FeO}$ contents vs. $\mathrm{TiO} 2$ content in lunar glasses (data in Table 1). Modified after Delano (1986) and Brown and Grove (2015 and references therein).

Figure 8 - Tektites specimens with the typical aerodynamic shapes and characteristic surface features. Image copyright: D.R. Neuville (square dimension=5mm)

Figure 9 - Photos of some tektites, including a moldavite (length $\sim 18 \mathrm{~mm}$ ) and two indochinites (length $\sim 25 \mathrm{~mm}$ ). Image copyright: M.R. Cicconi

Figure 10 - Approximate location and extension of the four strewn fields: NA (North American), IC (Ivory Coast), CE (central Europe) and Australasian (AA). The location of the known source craters are Chesapeake Bay (NA), Ries (CE) and Bosumtwi crater (IC). Image copyright: M.R. Cicconi.

Figure 11 - Photo of a LDG fragment. The sample has a clear pale yellow color and the typical wind erosion surface. Image copyright: D.R. Neuville (square dimension=5mm).

Figure 12 - Some fulgurite specimens with the characteristic irregular tube shapes. Image copyright: D.R. Neuville (square dimension $=5 \mathrm{~mm}$ ).

Figure 13 - Photographs of a fulgurite sample. The inner part is more smoothed and has a heterogeneous glassy material, whereas the outer portion is very irregular. Length of the specimen: $\sim 55 \mathrm{~mm}$. Image copyright: M.R. Cicconi

Figure 14 - Obsidian from Lipari (I). Image copyright: D.R. Neuville (square dimension $=5 \mathrm{~mm}$ )

Figure 15 - Arrowhead made of obsidian. Image copyright: D.R. Neuville (square dimension $=5 \mathrm{~mm})$. 
Figure 16 - TAS diagram for obsidians, perlites and pitchstones. Obsidian Data for 1) subalkalic silicic obsidians [137]; 2) from [151]; 3) from [152]; 4) from [153] and 5) from [147]. See also Table 1.

Figure 17 - Photograph of a pumice specimen from Glass Mountain (USA). The sample has the typical highly vesicular irregular texture. Image copyright: D.R. Neuville (square dimension $=5 \mathrm{~mm})$.

Figure 18 - Photograph of spherulitic obsidians (length $\sim 4 \mathrm{~cm}$; unknown locality). Spherulites are distributed homogeneously all over the samples with size ranging from 3.0 to $8.0 \mathrm{~mm}$. Image copyright: M.R. Cicconi

Figure 19 - Glass sample from Trinity site, Tularosa Basin, Alamogorgo (USA). This green trinitite fragment is glassy and vesiculated and is a product of the first atomic bomb blast on July 16, 1945. Image copyright: D.R. Neuville (square dimension=5mm).

Figure 20 - Microphotography of a pseudotachylite layer (dark layer) from the Nojima fault, Japan [189]. (Rectangular dimension: 0.5mm). Image copyright: D.R. Neuville.

Figure 21 - Low- and high-temperature measured values of viscosity for $\mathrm{SiO} 2$, tectosilicates (Ab, An and Or) and wollastonite (Wo) melts as a function of reciprocal temperature. (a) The viscosity measurements for a rhyolitic (Rhy), an andesitic (And) and a basaltic (Bas) melt are reported as symbols. (b) The viscosity measurements for a moldavite (mol) and an Australasian tektite (chi) are reported as symbols. . Lines are only guides for the eyes. Data in Tab. 2 and from [200]. Viscosity measurements were obtained following [201].

Figure 22 - Tg-scaled Arrhenius representation of liquid viscosities showing Angell's strongfragile pattern. Both tektites, mol and chi, exhibit approximate linearity, and thus an Arrhenian behaviour.

Figure 23a-Raman spectra for some natural silicate glasses and for a pure $\mathrm{SiO}_{2}$ glass in the range $300-1250 \mathrm{~cm}^{-1}$. The shape of the spectra change depending on the polymerization of the glasses, and on the presence/amount of other elements (such as $\mathrm{Fe}$ ).

Figure $23 b-$ continue of Fig. 23a

Figure 24 - Photo and light microscopy images of an obsidian specimen and the crystalline portion (spherulite). The Raman spectra collected both in the glassy and crystalline parts are reported. Beside the glass portion it was possible to identify feldspar minerals (blue and violet points), and magnetite/ilmenite, and hematite (orange, green and red points).

Figure $25-\mathrm{Fe}$ redox ratio vs T. Empty circles represent the theoretical Fe3+/Fetot values calculate for the indochinite tektite composition by using the model of Kress and Carmichael (1991, K \& C). The black squares are the Fe3+/Fetot estimated from the XAS data analysis at high temperatures, whereas the empty square represents the value at room temperature $(\sim 0.05$ $\pm 0.05)$. 
Table 1 - Average composition of the major oxides (wt\%) in several natural glasses.

\begin{tabular}{|c|c|c|c|c|c|c|c|c|c|c|c|c|c|c|}
\hline Sample & $\mathrm{SiO}_{2}$ & $\mathrm{TiO}_{2}$ & $\mathrm{Al}_{2} \mathbf{O}_{3}$ & $\mathrm{Cr}_{2} \mathrm{O}_{3}$ & $\begin{array}{c}\mathrm{Fe}_{2} \mathrm{O}_{3} \\
\text { or } \\
\mathrm{Fe}_{2} \mathrm{O}_{3} \text { tot } \\
\S \\
\S\end{array}$ & $\begin{array}{c}\text { FeO or } \\
\text { FeOtot } \\
\S \\
\end{array}$ & MnO & MgO & $\mathrm{CaO}$ & $\mathrm{Na}_{2} \mathrm{O}$ & $\mathbf{K}_{2} \mathbf{O}$ & $\begin{array}{c}\mathbf{H}_{2} \mathbf{O} \text { or } \\
\mathbf{H}_{2} \mathbf{O}^{+} \\
\left(^{*}\right)\end{array}$ & $\mathbf{P}_{2} \mathbf{O}_{5}$ & Reference \\
\hline \multicolumn{15}{|l|}{ Obsidian } \\
\hline \multirow{5}{*}{$\begin{array}{l}\text { Armenian and } \\
\text { Caucasian }\end{array}$} & 76.27 & 0.06 & 13.09 & & 0.52 & & 0.07 & 0.05 & 0.51 & 4.07 & 4.39 & & 0 & \multirow{5}{*}{ [151] } \\
\hline & 76.7 & 0.1 & 13.5 & & 0.66 & & 0.1 & 0.15 & 0.54 & 4.56 & 4.65 & & 0.02 & \\
\hline & 72.84 & 0.21 & 14.52 & & 1.8 & & 0.06 & 0.48 & 1.67 & 4.56 & 3.76 & & 0.09 & \\
\hline & 75.15 & 0.11 & 13.95 & & 0.94 & & 0.07 & 0.22 & 0.99 & 4.29 & 4.26 & & 0.03 & \\
\hline & 77.37 & 0.08 & 12.64 & & 0.59 & & 0.06 & 0.04 & 0.48 & 4.18 & 4.56 & & 0 & \\
\hline \multirow{3}{*}{ Mediterranian } & 74.72 & 0.09 & 13.4 & & 1.25 & & 0.08 & 0.08 & 0.59 & 3.44 & 5.26 & & 0.06 & \multirow{3}{*}{ [153] } \\
\hline & 73.77 & 0.18 & 13.68 & & 1.31 & & 0.11 & 0.13 & 0.75 & 3.34 & 5.63 & & 0.04 & \\
\hline & 75.05 & 0.13 & 12.97 & & 1.17 & & 0.08 & 0.11 & 0.57 & 3.34 & 5.51 & & 0.04 & \\
\hline Monte Arci (I) & 75.57 & 0.09 & 13.88 & & 1.28 & & 0.05 & & 0.57 & 3.55 & 4.71 & & & \multirow{7}{*}{ [147] } \\
\hline Monte Arci (I) & 74.84 & 0.14 & 14.02 & & 1.48 & & 0.04 & & 0.7 & 3.49 & 4.88 & & & \\
\hline Monte Arci (I) & 75.96 & 0.13 & 13.44 & & 1.23 & & 0.03 & & 0.54 & 3.36 & 4.99 & & & \\
\hline Monte Arci (I) & 73.68 & 0.3 & 14.33 & & 1.75 & & 0.03 & & 0.85 & 3.3 & 5.31 & & & \\
\hline Lipari (I) & 74.87 & 0.07 & 13.25 & & 1.63 & & 0.06 & & 0.69 & 4.16 & 4.66 & & & \\
\hline Palmarola (I) & 74.51 & 0.08 & 13.45 & & 1.61 & & 0.07 & & 0.44 & 4.79 & 4.43 & & & \\
\hline Pantelleria (I) & 71.2 & 0.19 & 7.66 & & 8.11 & & 0.27 & & 0.25 & 6.84 & 3.72 & & & \\
\hline \multirow{10}{*}{ Lipari (I) } & 75.55 & 0.06 & 12.83 & & & 1.6 & 0.06 & 0.04 & 0.69 & 4.13 & 5.03 & 0.21 & 0.01 & \multirow{10}{*}{ [152] } \\
\hline & 75.36 & 0.06 & 12.83 & & & 1.59 & 0.06 & 0.04 & 0.72 & 4.16 & 5.02 & 0.16 & 0.01 & \\
\hline & 75.48 & 0.07 & 12.82 & & & 1.58 & 0.07 & 0.04 & 0.7 & 4.16 & 5.04 & 0.16 & 0 & \\
\hline & 75.57 & 0.06 & 12.86 & & & 1.6 & 0.06 & 0.04 & 0.69 & 4.16 & 5.04 & 0.14 & 0.02 & \\
\hline & 75.62 & 0.08 & 12.63 & & & 1.48 & 0.07 & 0.04 & 0.72 & 4.2 & 5.15 & 0.15 & 0.01 & \\
\hline & 75.47 & 0.07 & 12.82 & & & 1.47 & 0.06 & 0.04 & 0.72 & 4.19 & 5.16 & 0.14 & 0.01 & \\
\hline & 75.37 & 0.07 & 12.84 & & & 1.57 & 0.07 & 0.04 & 0.72 & 4.19 & 5.13 & 0.14 & 0.01 & \\
\hline & 75.45 & 0.08 & 12.82 & & & 1.48 & 0.07 & 0.04 & 0.72 & 4.21 & 5.12 & 0.15 & 0.01 & \\
\hline & 74.42 & 0.08 & 12.77 & & & 1.5 & 0.07 & 0.04 & 0.72 & 4.2 & 5.18 & 0.14 & 0.01 & \\
\hline & 75.54 & 0.08 & 12.82 & & & 1.47 & 0.06 & 0.05 & 0.72 & 4.17 & 5.1 & 0.15 & 0.01 & \\
\hline \multirow{2}{*}{ Subalkalic } & 73.1 & 0.31 & 14.02 & & 0.46 & 1.30 & 0.05 & 0.39 & 1.58 & 4.54 & 3.20 & 0.08 & 0.04 & \multirow[t]{2}{*}{ [137] } \\
\hline & 66.8 & 0.64 & 16.13 & & 0.54 & 3.00 & 0.08 & 1.33 & 3.57 & 4.84 & 2.32 & 0.51 & 0.11 & \\
\hline
\end{tabular}




\begin{tabular}{|c|c|c|c|c|c|c|c|c|c|c|c|c|c|}
\hline & 71.9 & 0.49 & 14.33 & 0.13 & 2.06 & 0.06 & 0.46 & 1.71 & 4.88 & 3.13 & 0.49 & 0.09 & \\
\hline & 76.1 & 0.13 & 12.71 & 0.23 & 0.93 & 0.05 & 0.15 & 1.04 & 3.59 & 3.91 & 0.42 & 0.01 & \\
\hline & 74.3 & 0.12 & 13.34 & 0.35 & 1.17 & 0.05 & 0.05 & 0.84 & 4.55 & 4.03 & 0.09 & 0.01 & \\
\hline & 77.3 & 0.07 & 12.66 & 0.37 & 0.75 & 0.05 & 0.03 & 0.64 & 4.34 & 3.65 & 0.09 & 0.01 & \\
\hline & 76.97 & 0.14 & 12.25 & 0.39 & 0.81 & 0.05 & 0.15 & 0.90 & 3.89 & 3.89 & 0.22 & 0.03 & ] \\
\hline & 69.47 & 0.45 & 13.90 & 0.90 & 2.62 & 0.10 & 0.49 & 1.89 & 5.38 & 3.21 & 0.06 & 0.13 & [137] \\
\hline & 67.8 & 0.74 & 14.98 & 0.97 & 3.36 & 0.20 & 0.70 & 1.92 & 6.87 & 1.82 & 0.12 & 0.09 & \\
\hline & 77.2 & 0.10 & 12.84 & 0.20 & 0.35 & 0.05 & 0.07 & 0.58 & 3.65 & 4.59 & 0.06 & 0.01 & \\
\hline & 73.16 & 0.30 & 13.42 & 0.99 & 0.99 & 0.06 & 0.66 & 1.61 & 3.92 & 4.20 & 0.30 & 0.09 & \\
\hline & 76.60 & 0.07 & 12.69 & 0.35 & 0.58 & 0.06 & 0.04 & 0.58 & 3.80 & 4.73 & 0.09 & 0.01 & \\
\hline \multirow{2}{*}{ Turkey } & 75.09 & 0.16 & 13.87 & 1.05 & & 0.05 & 0.1 & 0.89 & 4.02 & 4.9 & & 0.02 & [6] \\
\hline & 76.26 & 0.09 & 13.48 & 0.7 & & 0.04 & 0.03 & 0.85 & 4.03 & 4.65 & & 0.01 & \\
\hline \multicolumn{14}{|l|}{ Perlites } \\
\hline & 74.26 & 0.09 & 12.22 & 0.91 & & 0.09 & 0.18 & 0.73 & 3.81 & 4.66 & $3.32 *$ & & [6] \\
\hline & 69.5 & & 13.53 & 1.86 & & & 1.14 & 0.33 & 3.06 & 5.55 & $5.94 *$ & & [6] \\
\hline & 72.88 & 0.06 & 14.22 & 0.7 & 0.5 & & & 1.49 & 4.03 & 2.82 & $4.52 *$ & & [6] \\
\hline & 72.78 & & 14.15 & 0.17 & & & & 0.82 & 4.51 & 2.48 & $4.35^{*}$ & & [6] \\
\hline & 74.3 & 0.13 & 12 & 0.77 & 0.36 & 0.06 & 0.08 & 0.56 & 4.04 & 4.69 & & & [6] \\
\hline & 73.67 & 0.12 & 12.93 & 0.63 & 0.99 & 0.03 & 0.12 & 1.41 & 3.14 & 4 & $3.29 *$ & & [6] \\
\hline & 73.7 & 0.1 & 12.6 & 2.1 & & 0.1 & & 0.7 & 3.7 & 4.6 & 2.4 & & [205] \\
\hline & 74.9 & 0.1 & 12.5 & 0.8 & & 0.2 & & 0.6 & 2.9 & 5 & 3 & & [205] \\
\hline & 71.97 & 0.11 & 10.34 & & 0.41 & 0.01 & 0 & 0.38 & 3.34 & 4.13 & 6 & & [150] \\
\hline & 67.59 & 0.14 & 12.76 & 0.76 & 2.08 & 0.08 & 0.31 & 1.33 & 3.28 & 4.37 & 5.3 & & [150] \\
\hline & 70.14 & 0.14 & 13.49 & 1.15 & 0.5 & 0.05 & 0.23 & 0.6 & 2.86 & 6.62 & 4.7 & & [150] \\
\hline & 70.02 & 0.12 & 11.37 & 0.97 & 0.09 & 0.01 & 0.28 & 2.03 & 1.88 & 3.9 & 6.5 & & [150] \\
\hline & 66.68 & 0.3 & 15.15 & 2.34 & 0.72 & 0.07 & 0.5 & 1.66 & 3.97 & 5.64 & 4.9 & & [150] \\
\hline & 71.96 & 0.19 & 11.89 & 0.84 & 0.14 & 0.05 & 0.34 & 1.09 & 2.35 & 4.45 & 6.1 & & [150] \\
\hline \multicolumn{14}{|c|}{ Pitchstones } \\
\hline & 71.75 & 0.12 & 14.99 & 0.28 & 0.53 & 0.04 & 0.26 & 0.98 & 2.97 & 2.83 & 5.54 & & \\
\hline & 73.37 & 0.16 & 10.78 & 0.96 & 1.02 & 0.37 & 0.15 & 0.77 & 3.78 & 4.21 & 4.52 & & \\
\hline & 73.5 & 0.17 & 11.59 & 1.77 & & 0.04 & 0.01 & 0.71 & 3.91 & 3.14 & 5.23 & & [6] \\
\hline & 67.88 & 0.79 & 12.22 & 5.6 & & 0.09 & 0.65 & 2.15 & 3.59 & 2.7 & 4.36 & & \\
\hline & 71.9 & 0.23 & 11.9 & 0.8 & 1.3 & 0.06 & 0.19 & 0.89 & 4.6 & 2.9 & 5.1 & & \\
\hline
\end{tabular}




\begin{tabular}{|c|c|c|c|c|}
\hline \multirow[t]{3}{*}{ Kilauea bulk rock } & 50.94 & 2.41 & 13.49 & \\
\hline & 51.49 & 2.77 & 13.33 & 0.05 \\
\hline & 52.14 & 2.48 & 13.61 & 0.046 \\
\hline \multirow[t]{13}{*}{ Kilauea glasses } & 51.94 & 2.46 & 13.63 & 0.03 \\
\hline & 52.11 & 2.33 & 13.7 & 0.04 \\
\hline & 52.06 & 2.56 & 13.55 & 0.02 \\
\hline & 52.43 & 2.10 & 13.75 & \\
\hline & 52.55 & 2.16 & 13.94 & \\
\hline & 52.55 & 2.16 & 13.94 & \\
\hline & 52.62 & 2.71 & 13.11 & \\
\hline & 52.44 & 2.14 & 13.91 & \\
\hline & 52.84 & 2.18 & 13.58 & \\
\hline & 52.63 & 2.17 & 13.76 & \\
\hline & 52.46 & 2.75 & 13.02 & \\
\hline & 52.61 & 2.49 & 13.53 & \\
\hline & 52.13 & 2.34 & 13.32 & \\
\hline \multirow{12}{*}{ Mauna Loa glasses } & 52.66 & 2.44 & 13.36 & \\
\hline & 52.78 & 2.16 & 13.62 & \\
\hline & 52.61 & 2 & 13.94 & \\
\hline & 52.54 & 2.3 & 13.6 & \\
\hline & 52.52 & 2.12 & 14.13 & \\
\hline & 52.61 & 2.55 & 13.68 & \\
\hline & 52.56 & 2.2 & 13.91 & \\
\hline & 52.16 & 1.97 & 13.62 & \\
\hline & 52.37 & 2.15 & 13.85 & \\
\hline & 52.65 & 2.26 & 13.78 & \\
\hline & 51.9 & 2.15 & 13.83 & \\
\hline & 52.16 & 2.15 & 13.81 & \\
\hline Pele's tears & 50.9 & 1.42 & 13.5 & \\
\hline \multirow{3}{*}{$\begin{array}{l}\text { Hawaiian Pele's } \\
\text { hair }\end{array}$} & 48.82 & 2.77 & 13.42 & \\
\hline & 50.26 & 2.69 & 13.48 & \\
\hline & 50.04 & 3.02 & 14.02 & \\
\hline
\end{tabular}

\begin{tabular}{|c|c|c|c|c|c|c|c|}
\hline & 11.3 & 0.17 & 7.99 & 11 & 2.19 & 0.42 & \\
\hline & 11.56 & 0.21 & 6.3 & 11.4 & 2.32 & 0.41 & \\
\hline & 10.95 & 0.16 & 6.84 & 11.05 & 2.35 & 0.42 & \\
\hline & 11.08 & 0.16 & 6.74 & 11.14 & 2.38 & 0.42 & \\
\hline & 10.85 & 0.16 & 7.04 & 11.06 & 2.35 & 0.38 & \\
\hline & 11.34 & 0.16 & 6.53 & 10.9 & 2.39 & 0.44 & \\
\hline & 11.10 & 0.17 & 6.58 & 10.72 & 2.34 & 0.39 & 0.24 \\
\hline & 10.76 & 0.16 & 6.61 & 10.69 & 2.36 & 0.48 & 0.28 \\
\hline & 10.76 & 0.16 & 6.61 & 10.69 & 2.36 & 0.48 & 0.28 \\
\hline & 12.26 & 0.21 & 5.36 & 10.10 & 2.52 & 0.56 & 0.29 \\
\hline & 10.90 & 0.21 & 6.28 & 10.65 & 2.41 & 0.41 & 0.23 \\
\hline & 11.11 & 0.15 & 6.27 & 10.68 & 2.35 & 0.38 & 0.22 \\
\hline & 11.13 & 0.18 & 6.27 & 10.73 & 2.36 & 0.4 & 0.27 \\
\hline & 12.42 & 0.22 & 5.46 & 10.07 & 2.49 & 0.6 & 0.35 \\
\hline & 11.56 & 0.21 & 5.79 & 10.3 & 2.2 & 0.56 & 0.27 \\
\hline & 12.02 & 0.2 & 5.94 & 10.41 & 2.37 & 0.44 & 0.26 \\
\hline & 12.06 & 0.17 & 5.9 & 10.4 & 1.99 & 0.43 & 0.32 \\
\hline & 11.32 & 0.19 & 6.39 & 10.61 & 2.33 & 0.38 & 0.22 \\
\hline & 10.61 & 0.18 & 6.63 & 10.55 & 2.26 & 0.4 & 0.25 \\
\hline & 11.91 & 0.23 & 5.92 & 10.42 & 2.26 & 0.39 & 0.25 \\
\hline & 11.06 & 0.15 & 6.5 & 10.73 & 1.91 & 0.4 & 0.25 \\
\hline & 11.58 & 0.19 & 5.65 & 10.07 & 2.52 & 0.58 & 0.34 \\
\hline & 10.7 & 0.19 & 6.81 & 10.61 & 1.98 & 0.43 & 0.25 \\
\hline & 10.79 & 0.18 & 7.81 & 10.47 & 2.2 & 0.37 & 0.23 \\
\hline & 10.61 & 0.21 & 6.8 & 10.73 & 2.24 & 0.41 & 0.28 \\
\hline & 10.78 & 0.17 & 6.48 & 10.73 & 2.3 & 0.45 & 0.26 \\
\hline & 11.18 & 0.17 & 6.81 & 10.97 & 2.22 & 0.34 & 0.21 \\
\hline & 10.97 & 0.18 & 6.72 & 10.96 & 2.26 & 0.34 & 0.23 \\
\hline & 13.8 & 0.25 & 4.67 & 8.81 & 2.83 & 1.39 & \\
\hline 1.7 & 9.9 & 0.18 & 9 & 11.32 & 2.25 & 0.58 & 0.24 \\
\hline 1.55 & 9.57 & 0.17 & 7.04 & 11.45 & 2.22 & 0.45 & 0.26 \\
\hline 1.72 & 9.45 & 0.17 & 6.93 & 11.44 & 2.42 & 0.57 & 0.26 \\
\hline
\end{tabular}




\begin{tabular}{|c|c|c|c|}
\hline \multirow[t]{2}{*}{ Hawaiian basalt } & 50.79 & 3.08 & 14.1 \\
\hline & 49.61 & 2.55 & 12.78 \\
\hline \multirow{3}{*}{$\begin{array}{l}\text { Kilauea Eruption } \\
1959\end{array}$} & 49.5 & 2.56 & 12.57 \\
\hline & 49.35 & 2.61 & 13.2 \\
\hline & 49.41 & 2.26 & 13.16 \\
\hline \multirow{4}{*}{ Basaltic glasses } & 50.34 & 2.49 & 12.48 \\
\hline & 49.95 & 2.54 & 13.77 \\
\hline & 54.08 & 1.84 & 14.06 \\
\hline & 49.13 & 2.5 & 13.26 \\
\hline \multirow{25}{*}{$\begin{array}{l}\text { Phonolitic glasses } \\
\text { Erebus } \\
\text { (Antarctica) }\end{array}$} & 54.95 & 1.04 & 19.87 \\
\hline & 55.62 & 1.05 & 19.58 \\
\hline & 55.75 & 1.02 & 19.67 \\
\hline & 55.7 & 1.03 & 19.6 \\
\hline & 55.78 & 1.01 & 19.65 \\
\hline & 55.78 & 1.02 & 19.61 \\
\hline & 55.73 & 1.02 & 19.63 \\
\hline & 55.01 & 0.99 & 19.98 \\
\hline & 55.74 & 1.02 & 19.64 \\
\hline & 55.08 & 1.01 & 20.05 \\
\hline & 55.69 & 1.01 & 19.71 \\
\hline & 55.02 & 1.01 & 20.07 \\
\hline & 55.82 & 1 & 19.75 \\
\hline & 55.75 & 0.99 & 19.74 \\
\hline & 54.93 & 1.03 & 20.01 \\
\hline & 55.61 & 0.98 & 19.71 \\
\hline & 55.9 & 0.98 & 19.69 \\
\hline & 55.63 & 0.97 & 19.7 \\
\hline & 55.41 & 1.01 & 19.74 \\
\hline & 54.97 & 1.03 & 19.9 \\
\hline & 55.12 & 0.99 & 19.91 \\
\hline & 55.09 & 1.01 & 19.83 \\
\hline & 54.85 & 1.02 & 19.9 \\
\hline & 55.17 & 1.01 & 19.79 \\
\hline & 55.12 & 1.02 & 19.91 \\
\hline
\end{tabular}

\begin{tabular}{|c|c|c|c|c|c|c|c|c|}
\hline 8.33 & 0.12 & 6.78 & 10.26 & 2.6 & 0.48 & & 0.29 & [238] \\
\hline 11.48 & 0.11 & 8.9 & 11.51 & 2.14 & 0.5 & 0.02 & 0.25 & \multirow{4}{*}{ [239] } \\
\hline 11.55 & 0.18 & 9.32 & 11.34 & 2.11 & 0.49 & 0.03 & 0.25 & \\
\hline 11.74 & 0.17 & 8.69 & 11.01 & 2.2 & 0.52 & 0.05 & 0.27 & \\
\hline 11.59 & 0.18 & 8.95 & 10.99 & 2.15 & 0.54 & 0.09 & 0.27 & \\
\hline 16.24 & 0.29 & 5.03 & 9.47 & 3.05 & 0.19 & \multirow{29}{*}{$\begin{array}{l}0.68^{*} \\
0.33^{*}\end{array}$} & & \multirow{4}{*}{ [6] } \\
\hline 12.8 & & 5.22 & 9.9 & 3.95 & 0.25 & & & \\
\hline 10.17 & 0.16 & 5.81 & 9.53 & 3.41 & 0.47 & & & \\
\hline 12.43 & 0.23 & 7.14 & 12.35 & 2.2 & 0.34 & & & \\
\hline 5.45 & 0.27 & 0.82 & 1.9 & 9.1 & 5.65 & & & \multirow{25}{*}{ [26] } \\
\hline 5.59 & 0.28 & 0.86 & 1.85 & 8.82 & 5.61 & & & \\
\hline 5.38 & 0.28 & 0.83 & 1.88 & 8.85 & 5.64 & & & \\
\hline 5.52 & 0.29 & 0.85 & 1.92 & 8.73 & 5.58 & & & \\
\hline 5.42 & 0.27 & 0.83 & 1.84 & 8.86 & 5.63 & & & \\
\hline 5.41 & 0.28 & 0.8 & 1.89 & 8.8 & 5.7 & & & \\
\hline 5.41 & 0.26 & 0.83 & 1.83 & 8.85 & 5.67 & & & \\
\hline 5.34 & 0.26 & 0.82 & 1.89 & 9.09 & 5.71 & & & \\
\hline 5.49 & 0.27 & 0.84 & 1.86 & 8.82 & 5.61 & & & \\
\hline 5.31 & 0.27 & 0.8 & 1.86 & 9.09 & 5.65 & & & \\
\hline 5.43 & 0.28 & 0.82 & 1.84 & 8.8 & 5.64 & & & \\
\hline 5.37 & 0.28 & 0.84 & 1.89 & 9.04 & 5.57 & & & \\
\hline 5.5 & 0.28 & 0.85 & 1.74 & 8.96 & 5.35 & & & \\
\hline 5.52 & 0.29 & 0.84 & 1.75 & 8.99 & 5.41 & & & \\
\hline 5.41 & 0.27 & 0.82 & 1.89 & 9.14 & 5.67 & & & \\
\hline 5.57 & 0.29 & 0.93 & 1.8 & 8.96 & 5.42 & & & \\
\hline 5.4 & 0.28 & 0.83 & 1.75 & 8.99 & 5.43 & & & \\
\hline 5.45 & 0.28 & 0.92 & 1.81 & 8.93 & 5.5 & & & \\
\hline 5.48 & 0.28 & 0.83 & 1.79 & 9.04 & 5.62 & & & \\
\hline 5.45 & 0.28 & 0.84 & 1.86 & 9.13 & 5.65 & & & \\
\hline 5.46 & 0.28 & 0.83 & 1.88 & 9.02 & 5.59 & & & \\
\hline 5.43 & 0.27 & 0.84 & 1.88 & 9.06 & 5.65 & & & \\
\hline 5.5 & 0.28 & 0.84 & 1.88 & 9.15 & 5.65 & & & \\
\hline 5.42 & 0.27 & 0.82 & 1.88 & 9.06 & 5.64 & & & \\
\hline 5.32 & 0.27 & 0.83 & 1.87 & 9.09 & 5.64 & & & \\
\hline
\end{tabular}




\begin{tabular}{|c|c|c|c|c|c|c|c|c|c|c|c|c|c|c|}
\hline & 55.11 & 1.03 & 19.85 & & & 5.34 & 0.27 & 0.83 & 1.88 & 9.07 & 5.65 & & & \\
\hline & 55 & 1.02 & 19.83 & & & 5.38 & 0.28 & 0.83 & 1.86 & 9.13 & 5.68 & & & \multirow{5}{*}[26]{} \\
\hline & 54.73 & 1.02 & 19.93 & & & 5.43 & 0.28 & 0.84 & 1.89 & 9.21 & 5.73 & & & \\
\hline & 54.94 & 1.02 & 19.92 & & & 5.39 & 0.28 & 0.83 & 1.87 & 9.13 & 5.67 & & & \\
\hline & 54.95 & 1.04 & 19.87 & & & 5.45 & 0.27 & 0.82 & 1.9 & 9.1 & 5.65 & & & \\
\hline & 55.35 & 1.01 & 19.8 & & & 5.43 & 0.28 & 0.83 & 1.87 & 9.04 & 5.64 & & & \\
\hline Tackylite (Kilauea) & 49.99 & 2.86 & 13.26 & & 1.88 & 9.76 & 0.16 & 8.39 & 10.61 & 2.26 & 0.54 & 0.16 & 0.3 & {$[18]$} \\
\hline \multicolumn{15}{|l|}{ Lunar glasses } \\
\hline Apollo 15 green $\mathrm{C}$ & 48 & 0.26 & 7.74 & 0.57 & & 16.5 & 0.19 & 18.2 & 8.57 & & & & & \\
\hline 15 green $\mathrm{A}$ & 45.5 & 0.38 & 7.75 & 0.56 & & 19.7 & 0.22 & 17.2 & 8.65 & & & & & \\
\hline 16 green & 43.9 & 0.39 & 7.83 & 0.39 & & 21.9 & 0.24 & 16.9 & 8.44 & & & & & \\
\hline 15 green $B$ & 46 & 0.4 & 7.92 & 0.55 & & 19.1 & - & 17.2 & 8.75 & & & & & \\
\hline 15 green $\mathrm{D}$ & 45.1 & 0.41 & 7.43 & 0.55 & & 20.3 & 0.22 & 17.6 & 8.43 & & & & & \\
\hline 15 green $\mathrm{E}$ & 45.2 & 0.43 & 7.44 & 0.54 & & 19.8 & 0.22 & 18.3 & 8.15 & & & & & \\
\hline 14 green $B$ & 44.8 & 0.45 & 7.14 & 0.54 & & 19.8 & 0.24 & 19.1 & 8.03 & 0.06 & 0.03 & & & \\
\hline $14 \mathrm{VLT}$ & 46 & 0.55 & 9.3 & 0.58 & & 18.2 & 0.21 & 15.9 & 9.24 & 0.11 & 0.07 & & & \\
\hline 11 green & 43.7 & 0.57 & 7.96 & 0.46 & & 21.5 & - & 17 & 8.44 & & & & & \\
\hline $17 \mathrm{VLT}$ & 45.3 & 0.66 & 9.6 & 0.4 & & 19.6 & 0.26 & 15 & 9.4 & 0.27 & 0.04 & & & \\
\hline 17 green & 44.3 & 0.91 & 6.89 & & & 20.2 & 0.23 & 19.5 & 7.4 & 0.1 & & & & \\
\hline 14 green $\mathrm{A}$ & 44.1 & 0.97 & 6.71 & 0.56 & & 23.1 & 0.28 & 16.6 & 7.94 & & & & & \\
\hline 15 yellow & 42.9 & 3.48 & 8.3 & 0.59 & & 22.1 & 0.27 & 13.5 & 8.5 & 0.45 & & & & [2] \\
\hline 14 yellow & 40.8 & 4.58 & 6.16 & 0.41 & & 24.7 & 0.3 & 14.8 & 7.74 & 0.42 & 0.1 & & & \\
\hline 17 yellow & 40.5 & 6.9 & 8.05 & 0.63 & & 22.3 & 0.25 & 12.6 & 8.64 & 0.39 & & & & \\
\hline 17 orange & 39.4 & 8.63 & 6.21 & 0.67 & & 22.2 & 0.28 & 14.7 & 7.53 & 0.41 & 0.04 & & & \\
\hline $\begin{array}{l}17 \text { orange } 74220- \\
\text { type }\end{array}$ & 38.5 & 9.12 & 5.79 & 0.69 & & 22.9 & & 14.9 & 7.4 & 0.38 & & & & \\
\hline 15 orange & 37.9 & 9.12 & 5.63 & 0.65 & & 23.7 & & 14.9 & 7.41 & 0.36 & & & & \\
\hline 17 orange & 38.8 & 9.3 & 7.62 & 0.66 & & 22.9 & 0.29 & 11.6 & 8.55 & 0.39 & & & & \\
\hline 11 orange & 37.3 & 10 & 5.68 & 0.63 & & 23.7 & & 14.3 & 7.62 & 0.31 & & & & \\
\hline 14 orange & 37.2 & 12.5 & 5.69 & 0.86 & & 22.2 & 0.31 & 14.5 & 7.04 & 0.28 & 0.29 & & & \\
\hline $15 \mathrm{red}$ & 35.6 & 13.8 & 7.15 & 0.77 & & 21.9 & 0.25 & 12.1 & 7.89 & 0.49 & 0.12 & & & \\
\hline $14 \mathrm{red}$ & 35.6 & 15.3 & 4.81 & & & 23.7 & & 13 & 6.49 & 0.5 & & & & \\
\hline $12 \mathrm{red}$ & 33.4 & 16.4 & 4.6 & 0.84 & & 23.9 & 0.3 & 13 & 6.27 & 0.05 & 0.12 & & & \\
\hline
\end{tabular}

Tektite 


\begin{tabular}{|c|c|c|c|}
\hline Normal australites & 70.4-72.4 & $\begin{array}{r}0.80- \\
0.83\end{array}$ & $\begin{array}{r}12.9- \\
14.3\end{array}$ \\
\hline $\begin{array}{l}\text { Normal } \\
\text { indochinites }\end{array}$ & $72.9-73.3$ & $\begin{array}{r}0.72- \\
0.89\end{array}$ & $\begin{array}{r}13.1- \\
13.5\end{array}$ \\
\hline $\mathrm{HMg}$ - australites & $64.8-77.0$ & $\begin{array}{r}0.66- \\
0.77\end{array}$ & $\begin{array}{r}10.7- \\
13.3\end{array}$ \\
\hline $\begin{array}{l}\text { Muong Nong-type } \\
\text { indochinites }\end{array}$ & 78.3 & 0.63 & 10.18 \\
\hline Muong Nong (s.l.) & $77.0-81.7$ & $\begin{array}{r}0.53- \\
0.72\end{array}$ & $\begin{array}{l}8.60- \\
11.41\end{array}$ \\
\hline $\begin{array}{l}\text { microtektites } \\
\text { Victoria Land } \\
\text { (Antartica) }\end{array}$ & $\begin{array}{r}67.5 \\
68.3 \\
68.4 \\
68.5 \\
68.9 \\
77 \\
77 \\
77.2 \\
77.6\end{array}$ & $\begin{array}{l}1.02 \\
0.99 \\
0.97 \\
0.97 \\
1.02 \\
0.71 \\
0.73 \\
0.72 \\
0.76\end{array}$ & $\begin{array}{l}17.6 \\
17.1 \\
17.3 \\
17.2 \\
17.3 \\
12.3 \\
12.3 \\
12.3 \\
12.2\end{array}$ \\
\hline $\begin{array}{l}\text { Georgiaites } \\
\text { Bediasites }\end{array}$ & $\begin{array}{l}79.8-83.6 \\
71.9-80.2\end{array}$ & $\begin{array}{l}0.42- \\
0.60 \\
0.59- \\
1.05\end{array}$ & $\begin{array}{l}9.50- \\
11.7 \\
11.2- \\
17.6\end{array}$ \\
\hline DSDP 612 & 72.93 & 0.81 & 14.94 \\
\hline $\begin{array}{l}\text { Muong Nong-type } \\
\text { Georgia }\end{array}$ & 84.2 & 0.34 & 9.19 \\
\hline Moldavites & $75.5-85.1$ & $\begin{array}{l}0.24- \\
0.74\end{array}$ & $\begin{array}{l}7.32- \\
11.4\end{array}$ \\
\hline Moldavites & $74.9-81.4$ & $\begin{array}{l}0.31- \\
1.40\end{array}$ & $\begin{array}{l}9.44- \\
13.8\end{array}$ \\
\hline Moldavites & $71.9-81.0$ & $\begin{array}{l}0.23- \\
0.50\end{array}$ & $\begin{array}{l}8.96- \\
12.7\end{array}$ \\
\hline Moldavite & 80.3 & 0.322 & 10.5 \\
\hline Ivory Coast & $67.0-69.3$ & $\begin{array}{l}0.52- \\
0.6\end{array}$ & $\begin{array}{l}15.8- \\
17.1\end{array}$ \\
\hline Ivory Coast & $\begin{array}{l}66.17- \\
68.48\end{array}$ & $\begin{array}{l}0.54- \\
0.61\end{array}$ & $16.28-17.72$ \\
\hline
\end{tabular}

\begin{tabular}{|c|c|c|c|c|c|}
\hline $\begin{array}{c}4.67- \\
4.97\end{array}$ & & $\begin{array}{r}2.16- \\
2.23\end{array}$ & $\begin{array}{r}2.94- \\
3.48\end{array}$ & $\begin{array}{r}1.32- \\
1.56\end{array}$ & $\begin{array}{r}2.41- \\
2.62\end{array}$ \\
\hline 4.47- & & $2.00-$ & $2.17-$ & $1.17-$ & 2.36- \\
\hline 4.49 & & 2.04 & 2.41 & 1.27 & 2.40 \\
\hline $3.85-$ & & 1.83- & 1.79- & $0.62-$ & $1.34-$ \\
\hline 8.63 & & 7.95 & 3.73 & 1.38 & 2.56 \\
\hline 3.75 & 0.06 & 1.43 & 1.21 & 0.92 & 2.41 \\
\hline $\begin{array}{r}3.18- \\
4.15\end{array}$ & & $\begin{array}{r}1.19- \\
1.65\end{array}$ & $\begin{array}{r}1.03- \\
1.63\end{array}$ & $\begin{array}{r}0.77- \\
1.07\end{array}$ & $\begin{array}{r}2.24- \\
2.55\end{array}$ \\
\hline 4.6 & & 3.2 & 4.08 & 0.24 & 0.9 \\
\hline 4.88 & & 4.31 & 3.97 & 0.22 & 0.73 \\
\hline 4.01 & & 3.47 & 3.66 & 0.21 & 0.81 \\
\hline 4.44 & & 3.31 & 3.71 & 0.27 & 0.88 \\
\hline 4 & & 3.52 & 3.91 & 0.23 & 0.8 \\
\hline 3.16 & & 1.99 & 3.14 & 0.25 & 0.93 \\
\hline 3.33 & & 1.95 & 2.8 & 0.29 & 1.18 \\
\hline 2.87 & & 2.22 & 2.74 & 0.26 & 1.25 \\
\hline 2.6 & & 1.89 & 3.44 & 0.26 & 0.89 \\
\hline $1.83-$ & & $0.37-$ & $0.40-$ & $1.00-$ & $2.22-$ \\
\hline 3.14 & & 0.69 & 0.69 & 1.53 & 2.51 \\
\hline 2.29- & & $0.37-$ & 0.49 & $1.20-$ & $1.60-$ \\
\hline 5.75 & & 0.95 & 0.96 & 1.84 & 2.43 \\
\hline 5.33 & 0.07 & 1.2 & 0.68 & 0.6 & 3.52 \\
\hline 1.43 & & 0.59 & 0.44 & 0.72 & 2.53 \\
\hline $1.08-$ & & $1.34-$ & $1.21-$ & $0.20-$ & $2.23-$ \\
\hline 2.93 & & 2.74 & 3.96 & 0.89 & 3.81 \\
\hline $1.72-$ & & $1.13-$ & $0.95-$ & $0.40-$ & $2.83-$ \\
\hline 3.50 & & 2.06 & 3.17 & 1.08 & 3.81 \\
\hline $1.28-$ & & $1.52-$ & $2.05-$ & $0.25-$ & $2.88-$ \\
\hline 2.86 & & 3.73 & 4.48 & 0.60 & 3.77 \\
\hline 1.69 & 0.041 & 1.69 & 1.35 & 0.552 & 3.48 \\
\hline $6.03-$ & & $2.64-$ & $0.71-$ & $1.54-$ & $1.70-$ \\
\hline 6.80 & & 3.93 & 1.61 & 2.44 & 2.07 \\
\hline 5.84- & & $2.98-$ & $1.21-$ & $1.53-$ & $1.73-$ \\
\hline 6.45 & & 4.39 & 1.52 & 2.08 & 2.13 \\
\hline
\end{tabular}




\begin{tabular}{|c|c|c|c|c|c|c|c|c|c|c|c|c|c|}
\hline \multirow{2}{*}{ High Si-K glass } & 86 & 0.47 & 6.93 & & & 2.45 & 0.05 & 1.15 & 0.38 & 0.38 & 2.21 & 0.02 & \multirow{2}{*}{ [101] } \\
\hline & 62.86 & 0.67 & 15.16 & & & 5.33 & 0.19 & 2.64 & 7.54 & 3.86 & 1.59 & 0.08 & \\
\hline \multirow{8}{*}{ Spherules K-Pg } & & & & & & & & & & & & & \multirow{8}{*}[244]{} \\
\hline & 62.25 & 0.71 & 15.06 & & & 5.4 & 0.18 & 2.77 & 8.12 & 3.78 & 1.59 & 0.07 & \\
\hline & 65.07 & 0.62 & 15.31 & & & 5.14 & 0.17 & 2.28 & 5.77 & 3.73 & 1.71 & 0.09 & \\
\hline & 65.45 & 0.63 & 15.29 & & & 5.03 & 0.18 & 2.35 & 5.65 & 3.72 & 1.55 & 0.02 & \\
\hline & 62.82 & 0.69 & 15.05 & & & 5.34 & 0.17 & 2.63 & 7.56 & 3.92 & 1.65 & 0.09 & \\
\hline & 63.53 & 0.63 & 15.61 & & & 4.87 & 0.17 & 2.33 & 6.72 & 4.08 & 1.78 & 0.1 & \\
\hline & 61.42 & 0.71 & 15.4 & & & 5.32 & 0.17 & 2.75 & 8.39 & 4.09 & 1.52 & 0.06 & \\
\hline & 63.3 & 0.68 & 15.31 & & & 5.44 & 0.18 & 2.58 & 7.23 & 3.65 & 1.5 & 0.06 & \\
\hline \multirow[t]{6}{*}{ LDG } & & & & \multirow{2}{*}{\multicolumn{2}{|c|}{0.01}} & & & & & & & \multirow{2}{*}{\multicolumn{2}{|c|}{ [121] }} \\
\hline & 98.44 & 0.08 & 0.55 & & & 0.09 & $<0.01$ & $<0.01$ & $<0.01$ & 0.01 & 0.01 & & \\
\hline & 98.27 & 0.17 & 1.3 & \multicolumn{2}{|l|}{0.01} & 0.12 & $<0.01$ & 0.01 & 0.01 & 0.03 & 0.01 & & [121] \\
\hline & 95.85 & 0.18 & 1.48 & \multicolumn{2}{|l|}{0.03} & 0.98 & 0.02 & 0.08 & 1.38 & 0.02 & 0.01 & \multirow{3}{*}{0.01} & [121] \\
\hline & 98.4 & 0.12 & 1.19 & & & 0.12 & & 0.011 & 0.01 & 0.005 & 0.009 & & [245] \\
\hline & 98 & 0.197 & 1.67 & & & 0.11 & 0.0015 & 0.003 & 0.01 & 0.01 & 0.01 & & [117] \\
\hline \multicolumn{14}{|l|}{ Darwin glass } \\
\hline & $84-89.3$ & $\begin{array}{r}0.52- \\
0.62\end{array}$ & $\begin{array}{r}6.75- \\
8.20\end{array}$ & & & $\begin{array}{r}1.08- \\
3.78\end{array}$ & & $\begin{array}{r}0.61- \\
1.13\end{array}$ & $\begin{array}{r}0.03- \\
0.18\end{array}$ & $\begin{array}{r}0.02- \\
0.06\end{array}$ & $\begin{array}{r}1.51- \\
2.93\end{array}$ & & [246] \\
\hline & 86.1 & 0.56 & 7.25 & & & 2.51 & & 0.85 & 0.09 & 0.04 & 2.04 & & [71] \\
\hline \multirow[t]{11}{*}{ Fulgurite } & 91.6 & 0.45 & 2.3 & & 0.76 & & 0.01 & 0.17 & 0.14 & 0.06 & 0.63 & 0.02 & [7] \\
\hline & 97.17 & 0.02 & 0.53 & & 0.17 & & 0.01 & 0.03 & 0.01 & 0.02 & 0.18 & 0.01 & [7] \\
\hline & 98.38 & 0.02 & 0.02 & & 0.02 & & 0.02 & 0 & 0.01 & 0.01 & 0.01 & 0.01 & [7] \\
\hline & 60.4 & 0.86 & 20.8 & & 5.9 & & 0.01 & 2.29 & 0.59 & 2.13 & 7 & 0.19 & [7] \\
\hline & 99.8 & 0.01 & 0.08 & & 0.03 & & 0.01 & 0.01 & 0.01 & 0.02 & 0.03 & 0 & [7] \\
\hline & 64.93 & 0.013 & 18.91 & & 0.2 & & 0.01 & 0.12 & 0.04 & 1.1 & 14.6 & 0.01 & [7] \\
\hline & 59.7 & 0.87 & 16.4 & & 5.5 & & 0.11 & 2.3 & 6.4 & 2.7 & 3.7 & 0.29 & [7] \\
\hline & 97.4 & 0.02 & 0.06 & & 0.06 & & 0.01 & 0.04 & 0.01 & 0.04 & 0.03 & 0.001 & [7] \\
\hline & 81.3 & 1.15 & 8.32 & & 8.48 & & 0.28 & 0.1 & 0.15 & 0.04 & 0.18 & 0.01 & [132] \\
\hline & 98.7 & 0 & 0.65 & & 0.17 & & & 0.02 & 0.08 & 0.07 & 0.26 & 0 & [132] \\
\hline & 81.5 & 0.2 & 10.3 & & 1.9 & & & 1.2 & 1.8 & 1.5 & 2.4 & 0 & [132] \\
\hline
\end{tabular}




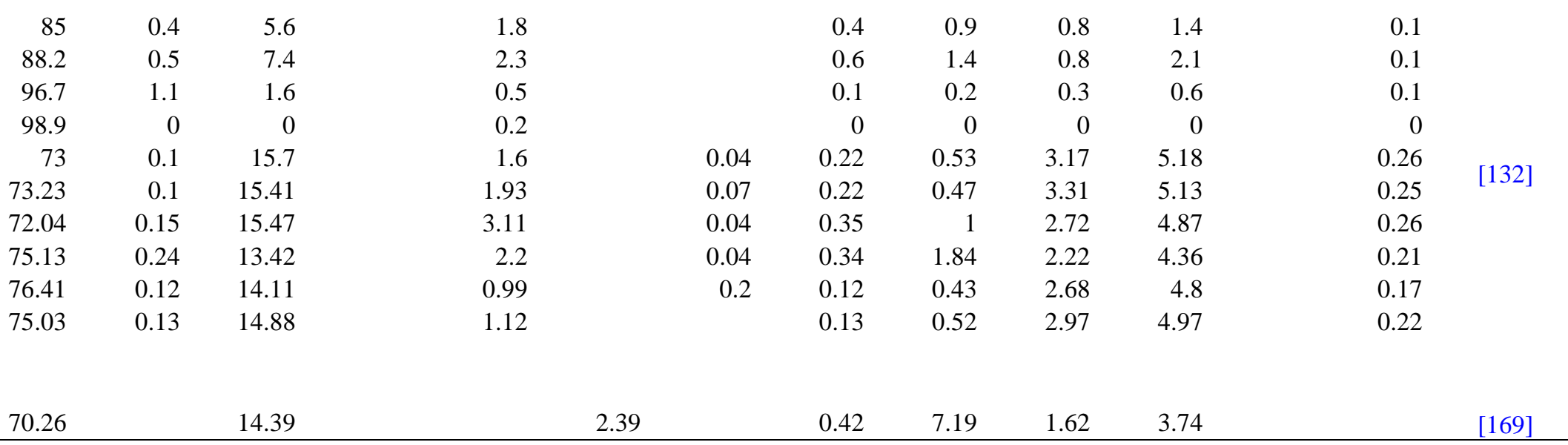

Trinitite

14.39

Notes: $\S \mathrm{Fe}$ oxide content is reported in literature in different ways: $\mathrm{FeO}$ total, or $\mathrm{Fe}_{2} \mathrm{O}_{3}$ total. Few authors reported both the $\mathrm{Fe}$ oxides. 
2058 Table 2A - Composition (wt\%) and some properties for tektites (chi and mol) shown in Fig. 19, 20 and $21 \mathrm{~A}$.

\begin{tabular}{lll}
\hline & Moldavite $(\mathrm{mol})$ & Indochinite (chi) \\
\hline $\mathrm{SiO}_{2}$ & 78.12 & 71.85 \\
$\mathrm{Al}_{2} \mathrm{O}_{3}$ & 9.56 & 12.94 \\
$\mathrm{TiO}_{2}$ & 0.32 & 0.83 \\
$\mathrm{CaO}$ & 2.73 & 2.48 \\
$\mathrm{MgO}$ & 2.09 & 1.96 \\
$\mathrm{Cr}_{2} \mathrm{O}_{3}$ & 0.01 & 0.03 \\
$\mathrm{MnO}$ & 0.06 & 0.14 \\
$\mathrm{FeO}$ & 1.61 & 4.44 \\
$\mathrm{Na} 2 \mathrm{O}$ & 0.36 & 1.21 \\
$\mathrm{~K}_{2} \mathrm{O}$ & 3.49 & 2.43 \\
& & \\
$\mathrm{density}\left(\mathrm{g} / \mathrm{cm}^{3}\right)( \pm 0.0005)$ & 2.3717 & 2.4277 \\
$\mathrm{Tg}(\mathrm{K})$ & 1070 & 1014 \\
$\mathrm{~S}_{\text {conf }}(\mathrm{Tg})\left(\mathrm{J} / \mathrm{molK}^{2}\right.$ & 13.4 & 11.9 \\
\hline
\end{tabular}

2059 

glass (bas).

\begin{tabular}{|c|c|c|c|c|c|}
\hline Basalt (bas) & & Moldavite (mol) & & Indochinite (chi) & \\
\hline $\mathrm{T}(\mathrm{K})$ & $\log \eta$ & $\mathrm{T}(\mathrm{K})$ & $\log \eta$ & $\mathrm{T}(\mathrm{K})$ & $\log \eta$ \\
\hline 936.4 & 12.53 & 1059.1 & 12.27 & 1004.9 & 12.24 \\
\hline 946.7 & 12.16 & 1069.8 & 12.02 & 1020.4 & 11.86 \\
\hline 952.6 & 11.83 & 1089.7 & 11.53 & 1021.5 & 11.77 \\
\hline 956.2 & 11.64 & 1101.4 & 11.25 & 1036.7 & 11.44 \\
\hline 962.5 & 11.37 & 1117.8 & 10.87 & 1038.2 & 11.35 \\
\hline 967.0 & 11.17 & 1128.2 & 10.64 & 1058.3 & 10.89 \\
\hline 976.3 & 10.86 & 1135.8 & 10.48 & 1066.2 & 10.67 \\
\hline 987.7 & 10.53 & 1138.8 & 10.44 & 1080.2 & 10.34 \\
\hline 999.5 & 10.15 & 1156.2 & 10.06 & 1090.2 & 10.20 \\
\hline 1002.2 & 10.05 & 1157.2 & 9.99 & 1099.8 & 9.92 \\
\hline 1011.8 & 9.80 & 1168.1 & 9.84 & 1107.7 & 9.71 \\
\hline 1020.8 & 9.52 & 1181.7 & 9.58 & 1122.4 & 9.48 \\
\hline 1029.8 & 9.21 & 1192.1 & 9.40 & 1138.2 & 9.20 \\
\hline 1473.0 & 1.43 & 1203.8 & 9.20 & 1144.1 & 9.08 \\
\hline 1523.0 & 1.15 & 1221.7 & 8.98 & 1873.2 & 3.30 \\
\hline 1573.0 & 0.90 & 1223.6 & 8.90 & 1923.2 & 3.10 \\
\hline 1623.0 & 0.67 & 1850.0 & 3.31 & 1973.2 & 2.97 \\
\hline 1673.0 & 0.47 & 1900.0 & 3.08 & 2023.2 & 2.73 \\
\hline 1723.0 & 0.29 & 1950.0 & 2.86 & 2073.1 & 2.53 \\
\hline 1773.0 & 0.13 & & & & \\
\hline
\end{tabular}

